\title{
De vergoeding van schade van derden in het Belgische aansprakelijkheidsrecht
}

\author{
Ingrid Boone en Bart Wylleman ${ }^{2}$
}

\section{Inleiding}

I. Een schadeverwekkende gebeurtenis treft vaak verschillende personen. Naast de direct getroffene kunnen ook anderen een negatieve weerslag ondervinden van de schade van de direct getroffene. ${ }^{3}$ Lindenbergh beschrijft, in navolging van Viaene, het beeld van de steen geworpen in vlak water: de schadeverwekkende gebeurtenis heeft een onmiddellijke impact voor de getroffene, maar daaromheen zijn veel kringen van anderen die ook op enigerlei wijze worden geraakt. ${ }^{4}$ Het bestaan van dit soort schade vindt zijn verklaring in het feit dat een persoon niet alleen staat, maar genegenheidsbanden en zakelijke verhoudingen heeft met anderen. ${ }^{5}$ Die banden en verhoudingen brengen mee dat schade die een persoon treft, uitstraalt of reflecteert naar anderen in diens omgeving, bijvoorbeeld naar zijn familieleden, werkgever en schuldeisers. De vergoeding van schade van derden, dit is schade die voortvloeit uit andermans schade, maakt het voorwerp uit van dit preadvies. Men spreekt in verband met deze derdenschade ook van schade door weerkaatsing, weerslagschade, gereflecteerde schade of afgeleide schade. ${ }^{6}$

2. Het Belgische buitencontractueel aansprakelijkheidsrecht maakt in beginsel7 geen onderscheid tussen schade van het rechtstreekse slachtoffer en gereflecteerde

Ingrid Boone is referendaris bij het Hof van Cassatie en gastdocent Universiteit Gent, Centrum voor Verbintenissenrecht.

2 Bart Wylleman is raadsheer in het Hof van Beroep te Gent en Academisch consulent Universiteit Gent, Centrum voor Verbintenissenrecht.

3 T. Vansweevelt en B. Weyts, Handboek Buitencontractueel Aansprakelijkheidsrecht, Antwerpen, Intersentia, 2009 (hierna verkort Buitencontractueel Aansprakelijkheidsrecht), 66o, nr. I049.

4 S. Lindenbergh, 'Schade van derden door verwonding of overlijden van een naaste', TPR 2002 (hierna verkort: 'Schade van derden'), (I42I) I423, nr. I.

5 D. Simoens, 'Buitencontractueel aansprakelijkheidsrecht. II, Schade en schadeloosstelling', in Beginselen van Belgisch Privaatrecht, Antwerpen, Kluwer/Story-Scientia, I999 (hierna verkort Schade en schadeloosstelling), 35 , nr. I9.

6 L. Cornelis, 'L'apparence trompeuse du dommage par répercussion', in Jeune Barreau de Liège (ed.), L'indemnisation du préjudice corporel, Luik, Ed. du Jeune Barreau de Liège, 1996 (hierna verkort: 'L'apparence trompeuse', (I49) I52-153; D. De Marez, De afgeleide schade van aandeelhouders van een naamloze vennootschap, Proefschrift ingediend met het oog op het behalen van de academische graad van doctor in de rechten aan de KUL, 2004, onuitg. (hierna verkort Afgeleide schade van aandeelhouders), 233, nr. 259; D. Simoens, Schade en schadeloosstelling, 35, nr. 19; T. Vansweevelt en B. Weyts, Buitencontractueel Aansprakelijkheidsrecht, 66o, nr. 1049.

7 Zie evenwel infra nr. 44 . 
schade van derden. De ruime regel van artikel I382 e.v. BW erkent de aanspraak van elke persoon die schade heeft geleden als gevolg van de onrechtmatige daad. Ook schade van anderen dan het rechtstreekse slachtoffer komt dus principieel in aanmerking voor vergoeding. ${ }^{8}$ Dit vloeit voort, zoals we verder zullen zien, uit het feit dat er geen a priori-beperkingen bestaan op de aard van de belangen die beschermd worden door het aansprakelijkheidsrecht of op de kring van aanspraakgerechtigden. ${ }^{9}$ Elk feitelijk nadeel dat voor een derde voortvloeit uit een aan het rechtstreekse slachtoffer onrechtmatig veroorzaakte schade kan aanleiding geven tot een vergoedingsaanspraak. Op voorwaarde dat hij een rechtmatig belang had bij het niet verwezenlijken van de gevolgen van een onrechtmatige daad, beschikt elke derde tegen de aansprakelijke over een vordering tot herstel van de zekere schade die hij persoonlijk heeft geleden ten gevolge van die daad. ${ }^{10}$ Een juridische band tussen de rechtstreeks getroffene en de persoon die de weerslagschade ondergaat, is niet vereist. ${ }^{\text {II }}$ Dit brengt mee dat de aansprakelijke blootgesteld kan worden aan de vorderingen van een in theorie onbeperkt aantal personen.

Ons aansprakelijkheidsrecht lijkt dus de sluizen wijd open te zetten voor een vloed aan schadeclaims. Dit is erg opmerkelijk, aangezien in vele andere rechtsstelsels precies de bekommernis leeft om het aansprakelijkheidsrecht niet te ver te laten uitdijen. ${ }^{12}$ De Draft Common Frame of Reference (DCFR) brengt die bekommernis in Boek VI (Non contractual liability arising out of damage) onder meer tot uiting door het concept 'legally relevant damage' te omschrijven. Dit concept strekt ertoe om irritaties en

8 L. Cornelis, 'L'apparence trompeuse', (I49) I52-I53; J. Ronse, L. De Wilde, A. Claeys en I. Mallems, 'Schade en schadeloosstelling', deel I, in APR, Gent, Story-Scientia, I984 (hierna verkort Schade), 97-IOO, nrs. I23-I 28 .

9 In vergoedingssystemen buiten het aansprakelijkheidsrecht wordt de kring van aanspraakgerechtigde schadelijders bij weerkaatsing soms wel uitdrukkelijk beperkt. De Arbeidsongevallenwet en de Beroepsziektenwet, bijvoorbeeld, kennen alleen aan bepaalde rechthebbenden (echtgenoot, kinderen) een rente toe in geval van een arbeidsongeval of een beroepsziekte met dodelijke afloop (art. Io-22bis Arbeidsongevallenwet; art. 33 Beroepsziektenwet). In artikel 29bis WAM, dat de BA-verzekeraar van een motorrijtuig betrokken in een verkeersongeval verplicht tot vergoeding van de schade als gevolg van letsel of overlijden geleden door het slachtoffer (met uitzondering van de bestuurder van een motorrijtuig) en zijn rechthebbenden, is het begrip 'rechthebbenden' niet nader omschreven. Betwist is of hieronder alleen de naaste verwanten moeten worden begrepen dan wel alle derden die schade lijden als gevolg van de letsels of het overlijden van het slachtoffer (waaronder bijvoorbeeld ook een vennootschap die inkomsten derft als gevolg van de arbeidsongeschiktheid van een zaakvoerder). Zie D. Simoens, 'Het begrip "rechthebbende" in het raam van art. 29bis WAM' (noot onder Pol. Mechelen I2 maart 2003), RW 2003-04, 393-394. Bij het Grondwettelijk Hof is een prejudicële vraag hangende over de verenigbaarheid van artikel 29bis WAM met het grondwettelijk gelijkheidsbeginsel, indien het artikel in die zin wordt geïnterpreteerd dat een rechtspersoon die als gevolg van een verkeersongeval schade bij weerkaatsing lijdt door het overlijden of het letsel van het rechtstreekse slachtoffer niet onder het begrip rechthebbende in de zin van dit artikel valt (zaak nr. 4995).

Io J. Ronse, L. De Wilde, A. Claeys en I. Mallems, Schade, 97, nr. I23.

II D. Simoens, Schade en schadeloosstelling, 36, nr. I9; T. Vansweevelt en B. Weyts, Buitencontractueel Aansprakelijkheidsrecht, 65I, nr. I032.

I2 Zie J. Spier (ed.), The limits of liability. Keeping the floodgates shut, Kluwer Law International, Den Haag, I996, I62 p. 
verstoringen waarvoor geen herstel verschuldigd is, te onderscheiden van schade die wel in aanmerking komt voor vergoeding. ${ }^{\mathrm{3}}$

In de Belgische doctrine is de zorg over een te ver uitdijend aansprakelijkheidsrecht niet prominent aanwezig. ${ }^{14}$ Steeds opnieuw wordt het principe van de integrale vergoeding van alle schade die het gevolg is van de onrechtmatige daad beklemtoond. De vraag of er geen beperkingen kunnen of behoren te worden gesteld, lokt telkens het antwoord uit dat de tekst en de strekking van de artikelen $1_{3} 82-{ }_{3} 83 \mathrm{BW}$ zich daartegen verzetten. ${ }^{15}$

Leidt dit uitgangspunt in de praktijk tot een onwerkbaar aansprakelijkheidsrecht of slagen wij er niettemin in om de aansprakelijkheid binnen redelijke grenzen te houden? Erkent de rechtspraak daadwerkelijk dat bijvoorbeeld niet alleen de echtgenoot en kinderen, maar ook een buur of een collega die erg is aangeslagen door het overlijden van het slachtoffer gerechtigd is op vergoeding voor zijn of haar smart? Moet de aansprakelijke ook het omzetverlies vergoeden van de apotheker die door het overlijden van het slachtoffer een goede klant verliest? Kan een werkgever van wie een aantal werknemers uren in de file staat als gevolg van een verkeersongeval aanspraak maken op vergoeding voor de arbeidsprestaties die hij daardoor derft? En tot slot - om de problematiek helemaal scherp te stellen - zijn ook de kinderen van een (serie)moordenaar of verkrachter geen indirecte slachtoffers van de gruweldaden van hun vader of moeder? ${ }^{16}$

3. Centraal in dit preadvies staat de vraag of, ondanks het beginsel dat elke persoon die schade lijdt als gevolg van een onrechtmatige daad gerechtigd is op vergoeding, de aansprakelijkheid voor schade van derden toch wordt begrensd en hoe dit desgevallend gebeurt. Om die vraag te kunnen beantwoorden, staan we eerst even stil bij een opvallend kenmerk van het Belgische buitencontractueel aansprakelijkheidsrecht: de afwezigheid van juridische instrumenten die erop gericht zijn om de mogelijke aanspraken te beperken. Daarna onderzoeken wij tot welke resultaten de toepassing van het buitencontractueel aansprakelijkheidsrecht leidt voor (bepaalde categorieën van) schadelijders bij weerkaatsing. De problematiek van schade van

I3 C. von Bar en E. Clive (eds.), Principles, definitions and model rules of European private law, Draft Common Frame of Reference (DCFR), Full Edition, Vol. 4, München, Sellier, 2009 (hierna verkort: Principles DCFR, Vol. 4), 3139 e.v. Zie infra nr. I3.

I4 Veelzeggend in dit verband is de eerste zin van de bijdrage van A. Van Oevelen ('La modération de la réparation du dommage dans le droit belge de la responsabilité civile extra contractuelle', 65, hierna verkort: 'La modération de la réparation du dommage') aan het eerder geciteerde boek The limits of liability. Keeping the floodgates shut: 'Pour le rapporteur belge le thème de ce colloque ne pose guère de problèmes. En effet, en matière de la réparation du dommage par suite daune responsabilité civile extra-contractuelle, le droit belge adhère au principe de la réparation intégrale'.

I5 J. Ronse, L. De Wilde, A. Claeys en I. Mallems, Schade, 98, D. Simoens, Schade en schadeloosstelling, I5, A. Van Oevelen, 'La modération de la réparation du dommage', 72.

I6 De Amerikaanse Melissa G. Moore was een tiener toen aan het licht kwam dat haar vader een seriemoordenaar was. In een interview gepubliceerd in De Morgen (I6 januari 2010) naar aanleiding van haar boek Shattered Silence waarin zij beschrijft hoe het is om de dochter van een seriemoordenaar te zijn, vertelt zij dat enkele familieleden van de slachtoffers zelf contact met haar zochten omdat zij haar ook beschouwden als een slachtoffer van haar vader. Maar volgens haar ervaring denken andere mensen niet aan de kinderen van een seriemoordenaar of -verkrachter. Zij zijn 'tweederangsslachtoffers' en lijden meestal in stilte. 
derden is naar haar aard in feite eindeloos. ${ }^{17}$ De dood van bijvoorbeeld een acteur als gevolg van een ongeval kan niet alleen aan zijn familie leed berokkenen, maar ook aan zijn vrienden en talrijke fans en kan bovendien nadelige gevolgen hebben voor de regisseur die een film met de betrokken acteur aan het opnemen was. Om het preadvies beheersbaar te houden en de vergelijking met het Nederlandse recht aan de hand van het Nederlandse preadvies te bevorderen, bespreken wij vijf categorieën van derde-schadelijders. Eerst komt de vergoeding van de personen die een nauwe persoonlijke relatie hebben met het slachtoffer, dit zijn de zogenoemde naasten en nabestaanden, aan de orde. In de tweede plaats bespreken wij de positie van derden die naar aanleiding van de schade van het slachtoffer bepaalde uitkeringen of prestaties moeten verrichten (zoals de eigenschadeverzekeraar van het slachtoffer of de brandweerdienst). Een derde en een vierde categorie vormen respectievelijk de schuldeisers en de aandeelhouders van de rechtstreeks benadeelde. Tot slot is er een 'restcategorie' van personen die, hoewel zij geen nauwe persoonlijke relatie hebben met het slachtoffer, noch diens schuldenaar, schuldeiser of aandeelhouder zijn, toch nadelig geraakt worden door het schadegeval. Het gaat bijvoorbeeld om een handelsagent die wegens een file veroorzaakt door een verkeersongeval een belangrijke commerciële afspraak misloopt.

Waar mogelijk zullen wij de oplossingen die het Belgische recht voorschrijft toetsen aan de modelregels van de DCFR.

4. Een laatste bedenking vooraf. Zoals verder zal blijken, is het soms onduidelijk of bepaalde nadelen als een eigen schade van de rechtstreeks getroffene dan wel als weerkaatste schade van derden te kwalificeren is. Bijvoorbeeld bij hulp verstrekt door naasten van het slachtoffer rijst de vraag wie nu eigenlijk schade lijdt: de rechtstreeks getroffene, vanwege de nood aan hulp van derden, of de naasten, vanwege de inspanningen en kosten om het slachtoffer bij te staan ${ }^{18}$ Het onderscheid tussen rechtstreekse slachtoffers en schadelijders bij weerkaatsing is trouwens zelf ook niet altijd duidelijk. Denk bijvoorbeeld aan het geval waarin een pasgeboren kind ontvoerd wordt maar enkele dagen later gezond en wel wordt teruggebracht. Het kind heeft aan dit gebeuren niets overgehouden (behoudens eventuele smart wanneer het later verneemt wat er in zijn eerste levensdagen is voorgevallen), maar de ouders hebben onbeschrijflijke angsten doorstaan als gevolg van wat er met hun kind is gebeurd. ${ }^{19}$ De aanduiding 'schade van derden' is derhalve niet volkomen. ${ }^{20}$

\section{Geen a priori beperkingen op de vergoedbaarheid van derdenschade}

5. Een opvallend kenmerk van het Belgische buitencontractueel aansprakelijkheidsrecht, in vergelijking met andere rechtsstelsels, is de afwezigheid van mechanismen

\footnotetext{
Zie ook S. Lindenbergh, 'Schade van derden', (I42I) I424, nr. 3.

Infra nr. 24-26.

Luik I7 februari 1997, RGAR I998, nr. I3.0I9.

Zie ook S. Lindenbergh, 'Schade van derden', (I42I) I424-I425, nr. 4.
} 
die ertoe strekken om de aansprakelijkheid binnen bepaalde grenzen te houden. ${ }^{2 \mathrm{I}}$ Behalve conventionele regelingen waarbij partijen hun aansprakelijkheid beper$k^{22}{ }^{22}$ en de enkele gevallen van (risico)aansprakelijkheid waarvoor de wetgever de aansprakelijkheid heeft beperkt door een financieel plafond, een vrijstelling of de uitsluiting van bepaalde soorten schade, ${ }^{23}$ kent ons buitencontractueel aansprakelijkheidsrecht geen regels die erop gericht zijn de mogelijke aanspraken te beperken.

6. In tegenstelling tot het Nederlandse recht, staat het Belgische recht in beginsel afwijzend ten aanzien van de leer van de relatieve onrechtmatige daad. ${ }^{24}$ De overtreding van een rechtsnorm die een bepaald gedrag voorschrijft of verbiedt, maakt een fout uit die door eenieder (die als gevolg van de normovertreding schade lijdt) kan worden ingeroepen als grondslag voor een aanspraak tot schadevergoeding, ook door personen wier belangen niet beschermd worden door de norm. Sporen van de relativiteitsleer zijn niettemin terug te vinden in ons aansprakelijkheidsrecht, bijvoorbeeld in de rechtspraak volgens welke de vermoedens van aansprakelijkheid vervat in de artikelen $\mathrm{I}_{3} 84$ e.v. BW een meer doeltreffende bescherming willen bieden aan degenen die rechtstreeks schade hebben geleden zodat zij dan ook alleen door die rechtstreekse slachtoffers kunnen worden aangevoerd. ${ }^{25}$ Hieruit wordt onder meer afgeleid dat de vermoedens van aansprakelijkheid niet als basis kunnen dienen voor een vordering tot vrijwaring. ${ }^{26}$ Deze jurisprudentiële regel heeft echter geen bijzondere gevolgen voor schadelijders bij weerkaatsing. ${ }^{27} \mathrm{Zij}$ staat er niet aan in de weg dat bijvoorbeeld nabestaanden van een slachtoffer omgekomen bij een ongeval te wijten aan een gebrekkige zaak, schadevergoeding kunnen verkrijgen op grond van artikel 1384 , eerste lid, BW van de bewaker van de zaak. ${ }^{28}$

7. Zoals bekend hanteert het Belgische recht met de equivalentieleer een zeer brede causaliteitsleer. Om causaal te zijn is vereist, maar meteen ook voldoende, dat de fout een noodzakelijke voorwaarde was voor de schade, met andere woorden dat de

Zie in dezelfde zin m.b.t. het Franse recht: J.-S. Borghetti, 'Les intérêts protégés et l'étendue des préjudices réparables en droit de la responsabilité civile extra-contractuelle', in J.-S. Borghetti, O. Deshayes en C. Peres (eds.), Etudes offertes à Geneviève Viney, Parijs, LGDJ, 2008 (hiera verkort: 'Les intérêts protégés'), I45.

22 Zie T. Vansweevelt en B. Weyts, Buitencontractueel Aansprakelijkheidsrecht, 877-923.

23 Zie H. Bocken en I. Boone, Het buitencontractueel aansprakelijkheidsrecht en andere schadevergoedingsmechanismen, Brugge, die Keure, 2010 (hierna verkort: Aansprakelijkheidsrecht en andere schadevergoedingsmechanismen), I74, nr. 283-284.

24 E. Dirix, Het begrip schade, Antwerpen, Maklu, I998, 22, nr. II; J. Limpens, 'La théorie de la relativité aquilienne en droit comparé', in Mélanges offerts à R. Savatier, Parijs, I965, (559) 573-575; J. Ronse, L. De Wilde, A. Claeys en I. Mallems, Schade, 24-26, nrs. Ig-2I; S.R.L. Van Nuijs, 'Relativiteit ten aanzien van de onrechtmatige daad. Vergelijkend onderzoek van het Nederlands en Belgisch recht aangaande aansprakelijkheidsbeperking via een relativiteitsvereiste', RW 19808I, (6I8) 625 en 638.

25 O.m. Cass. 5 december 1997, Arr.Cass. 1997, I293; Cass. 4 juni 2007, RGAR 2008, nr. I4.36r; Cass. 22 oktober 2007, RGAR 2008, nr. I4.4IO, concl. J.-F. Leclercq.

26 Cass. 2 september 1976, Arr.Cass. 1977, 6; Cass. 4 juni 2007, RGAR 2008, nr. I4.36I.

27 Contra Cornelis, 'L'apparence trompeuse', 176 e.v.

28 Gent Io oktober 2008, NJW 2009, 369, noot IB. 
schade zonder de fout niet zou zijn ontstaan zoals ze zich heeft voorgedaan. ${ }^{29}$ Een verdere selectie tussen feitelijke oorzaken wordt niet gemaakt. Deze zijn causaal equivalent. Om tot aansprakelijkheid te leiden, moet de fout dus niet de onmiddellijke of rechtstreekse oorzaak zijn van de schade; tussenkomende factoren doen in beginsel geen afbreuk aan het causaal verband tussen de fout en de schade. De schade moet bovendien niet het normale of voorzienbare gevolg zijn van de fout.

Voor weerkaatste schade van derden geldt de gewone causaliteitsleer evenzeer als voor schade van het rechtstreekse slachtoffer. Er moet alleen een stap verder worden gezet in de causaliteitsketen, ${ }^{30}$ soms zelfs verschillende stappen, zoals in het geval van de nabestaanden die schade ondervinden door de zelfmoord van een familielid dat een depressie had opgelopen wegens het overlijden van het eerste slachtoffer: ${ }^{3^{I}}$ weerkaatsing in het kwadraat. Het feit dat de afstand tussen de onrechtmatige daad en de weerkaatste schade doorgaans groter is dan bij de schade van het rechtstreekse slachtoffer, is volgens de equivalentieleer geen reden om het causaal verband tussen de schade en de fout te ontkennen. ${ }^{32}$

8. Volgens de traditionele opvatting leent ook het schadevereiste zich niet tot inperking van de kring van aanspraakgerechtigden. ${ }^{33}$ Schade wordt immers gewoonlijk omschreven als het negatieve verschil tussen twee toestanden: de toestand waarin het slachtoffer zich bevindt na het schadegeval en de toestand waarin het zich zou hebben bevonden als de onrechtmatige daad niet was gepleegd. ${ }^{34}$ Anderzijds geeft men toe dat schade geen louter feitelijk gegeven is, maar ook een juridisch begrip en dus normatief. 35 Niet elk verlies of nadeel komt dan ook in aanmerking voor vergoeding. De benadeelde moet kunnen bogen op de aantasting van een rechtmatig belang. ${ }^{36}$ In beginsel bestaan er geen verdere beperkingen met betrekking tot de aard van de belangen die in aanmerking worden genomen: naast de lichamelijke integriteit van de mens, zijn psychisch welzijn en zijn genegenheidsbanden met anderen, de privacy en mogelijkheid tot zelfbeschikking, zakelijke rechten en

29 Bijv. Cass. 3I januari 2008, NJW 2008, 44I, noot IB; Cass. 5 juni 2008, De Verz. 2008, noot H. Bocken; Cass. I7 december 2009, AR C.09.orgo.N. Zie ook H. Bocken en I. Boone, 'Causaliteit in het Belgische recht', TPR 2002, (I625) I632; J.-L. Fagnart, La causalité, Kluwer, 2008, 50-5I; B. Dubuisson, V. Callewaert, B. De Coninck en G. Gathem, La responsabilité civile. Chronique de jurisprudence 1996-2007. Vol. 1 : Le fait générateur et le lien causal, Brussel, Larcier, 2009, 342, nr. 388; M. Van Quickenborne, 'Overzicht van rechtspraak. Aansprakelijkheid uit onrechtmatige daad 2000-2007. Deel I. Oorzakelijk verband', TPR 20I0, (283) 292; W. Van Gerven m.m.v. S. Covemaeker, Verbintenissenrecht, Leuven, Acco, 2006, 429.

30 D. De Marez, Afgeleide schade van aandeelhouders, 20I, nr. 23I.

3 I Luik 25 juni ig86, JLMB ig86, 44I en RGAR I988, II.370.

32 D. De Marez, Afgeleide schade van aandeelhouders, 235, nr. 259.

33 A. Van Oevelen, 'La modération de la réparation du dommage', 72

34 E. Dirix, Het begrip schade, I6, nr. 5; D. Simoens, Schade en schadeloosstelling, I5, nr. 6; J. Ronse, L. De Wilde, A. Claeys en I. Mallems, Schade, 8, nr. 5.2; W. Van Gerven m.m.v. S. Covemaeker, Verbintenissenrecht, Leuven, Acco, 2006, 447-448; T. Vansweevelt en B. Weyts, Buitencontractueel Aansprakelijkheidsrecht, 633, nr. IoII; A. Van Oevelen, G. Jocqué, C. Persyn en B. De Temmerman, 'Overzicht van rechtspraak. Onrechtmatige daad. Schade en schadeloosstelling (1993-2006)', TPR 2007 (hierna verkort 'Overzicht van rechtspraak. Schade en schadeloosstelling', (933) 94I. E. Dirix, 'Abstracte en concrete schade', RW 2000-200I, I329; D. Simoens, Schade en schadeloosstelling, 15 , nr. 6.

36 Infra nr. 9 . 
gebruiksrechten op roerende en onroerende goederen, komen ook immateriële waarden als reputatie en eer en louter economische belangen in aanmerking voor bescherming door het aansprakelijkheidsrecht. ${ }^{37}$

9. In de eerste helft van de vorige eeuw hebben verschillende auteurs (waaronder Dabin en De Page) voorgehouden dat er alleen van schade kan worden gesproken wanneer de benadeelde de krenking van een recht of het verlies van een voordeel dat men uit een recht mocht verwachten, kan doen gelden..$^{38}$ Deze leer van de rechtskrenking werd vooral verdedigd om een dam op te werpen tegen al te talrijke aanspraken van schadelijders bij weerkaatsing. Het spreekt immers vanzelf dat met deze theorie het aantal mogelijke aanspraken $a$ priori wordt beperkt. ${ }^{39}$ In een principearrest van I6 januari 1939 heeft het Hof van Cassatie de theorie van de rechtskrenking evenwel verworpen, naar aanleiding van een geval waarin een broer, die met zijn zus samenwoonde en mee van haar inkomsten genoot, vergoeding vorderde voor het verlies aan inkomsten als gevolg van het overlijden van zijn zus. Het gegeven dat de broer geen recht had op een deel van het inkomen van zijn zus, was volgens het Hof geen beletsel voor een aanspraak op vergoeding; de aantasting van een belang volstaat. Vereist is wel dat het gaat om een rechtmatig belang. ${ }^{\circ}$ Het verlies van een onrechtmatig voordeel, zoals het verlies van inkomsten uit zwartwerk, komt niet in aanmerking voor vergoeding. ${ }^{4 \mathrm{I}}$ In het verleden werd het vereiste van rechtmatigheid aangegrepen om de vordering tot schadevergoeding van personen die samenwonen buiten huwelijk bij overlijden van een van hen af te wijzen. ${ }^{42}$ Men was van oordeel dat een dergelijke relatie geen rechtmatig voordeel oplevert. ${ }^{43}$ Nadien werd deze regel beperkt tot overspelige relaties ${ }^{44}$ en na de depenalisatie van overspel ${ }^{45}$ uiteindelijk volledig opgegeven. ${ }^{46}$ De rechtmatigheid van deze aanspraak wordt niet meer in vraag gesteld. ${ }^{47}$ Wel wordt soms de zekerheid van de economische schade waarvoor de ongehuwde partner vergoeding vordert, betwist. ${ }^{48}$

Io. Voorts moet het geschonden belang een eigen of persoonlijk belang zijn. Men kan enkel schadevergoeding vorderen voor persoonlijk geleden schade. ${ }^{49}$ Dit ver-

37 H. Bocken en I. Boone, Aansprakelijkheidsrecht en andere schadevergoedingsmechanismen, 52-53.

38 Zie over deze theorie J. Ronse, L. De Wilde, A. Claeys en I. Mallems, Schade, I2-I7, nrs. 9-I2; D. Simoens, Schade en schadeloosstelling, I6-I8, nr. 7.

39 E. Dirix, Het begrip schade, I8, nr. 7; J. Ronse, L. De Wilde, A. Claeys en I. Mallems, Schade, 98, nr. 125

40 Cass. 16 januari i939, Pas. I939, I, 25.

$4 \mathrm{I}$ Cass. I4 mei 2003, Pas. 2003, I, 982, RGAR 2003, nr. I3.767, concl. J. Spreutels, RCJB 2004, I35, noot J. Kirkpatrick en RW 2005-06, 743 .

42 Cass. 2I april I958, Pas. I958, I, 92 I.

43 Zie J. Ronse, Schade en schadeloosstelling (onrechtmatige daad), Brussel, Larcier, I953, nr. 53.

44 Cass. 30 november I98I, RW I982-83, I688.

45 Wet 20 mei I 987 tot opheffing van de artikelen 387 en 380 van het Strafwetboek inzake overspel.

46 Cass. I februari I989, Arr.Cass. I989, 654; Cass. I5 februari I990, Arr.Cass. I989-90, 776.

47 D. De Callataÿ en N. Estienne, La responsabilité civile. Chronique de jurisprudence 1996-2007. Volume 2 : Le dommage, Brussel, Larcier, 2009 (hierna verkort Chronique de jurisprudence. Le dommage), 2 I-22.

48 Zie infra nr. 37.

49 R.O. Dalcq, Traité de la responsabilité civile, II, in Les Novelles, Droit civil, Brussel, Larcier, I962 (hierna verkort Traité, II), nr. 2943 e.v. 
eiste stelt geen principieel probleem voor schadelijders bij weerkaatsing. De (morele of economische) schade die zij lijden is immers ook persoonlijke schade..$^{\circ}$ Wel kan het vereiste van een persoonlijke schade tot discussie leiden wanneer anderen dan het rechtstreekse slachtoffer kosten of inspanningen hebben gedaan ten behoeve van dit slachtoffer. Daarbij rijst dan de vraag of deze kosten (zoals verplaatsingskosten) en inspanningen (zoals hulp aan het slachtoffer) eigen schade van het slachtoffer zijn of van degene die ze gedaan hebben. ${ }^{.1}$ Ook bij afgeleide schade van schuldeisers en aandeelhouders wordt het persoonlijk karakter van de schade soms in vraag gesteld..$^{2}$

II. Om voor vergoeding in aanmerking te komen moet de schade ook zeker zijn. Aan het vereiste van zekerheid is voldaan als de schade dermate waarschijnlijk is dat de rechter niet ernstig aan het tegendeel moet denken, ook al is dit theoretisch nog mogelijk.53 De schade moet met andere woorden vaststaan en niet gesteund zijn op loutere veronderstellingen of gissingen..$^{54}$ Zoals we verder zullen zien, is de zekerheid van het bestaan van schade in de praktijk uitgegroeid tot een van de belangrijkste instrumenten om (te ver verwijderde) aanspraken van schadelijders bij weerkaatsing te ontmoedigen. De feitenrechter beschikt immers op dit vlak over een ruime beoordelingsvrijheid:55 hij oordeelt - weliswaar binnen de grenzen van de vordering - op onaantastbare wijze in feite, over het bestaan van de door een onrechtmatige daad veroorzaakte schade. ${ }^{56}$ Ook het vaststellen van de omvang van de schade en van het bedrag dat vereist is om die te vergoeden, behoort tot de soevereine beoordelingsmacht van de feitenrechter, ${ }^{57}$ al moet hij daarbij bepaalde regels respecteren (zoals de regel van het integrale schadeherstel en van de begroting in concreto, op het ogenblik van de uitspraak) waarvan het Hof van Cassatie de naleving controleert. Die regels gelden evenzeer voor schade van het rechtstreekse slachtoffer als voor weerkaatste schade van derden.

Bij de begroting van persoonsschade speelt de Indicatieve Tabel een belangrijke uniformerende rol. Deze tabel, opgesteld op initiatief van het Nationaal Verbond van Magistraten van eerste aanleg en het Koninklijk Verbond van Vrede- en politierechters, bevat bedragen voor de begroting ex aequo et bono van bepaalde schade-

50 D. De Marez, Afgeleide schade van aandeelhouders, 207; T. Vansweevelt en B. Weyts, Buitencontractueel Aansprakelijkheidsrecht, 650, nr. 1032.

5I Zie infra nr. 2I e.v.

52 Zie infra nr. 64 en nr. 74.

53 A. Van Oevelen, G. Jocqué, C. Persyn en B. De Temmerman, 'Overzicht van rechtspraak. Schade en schadeloosstelling', 963 en de verwijzingen aldaar.

54 W. Van Gerven m.m.v. S. Covemaeker, Verbintenissenrecht, Leuven, Acco, 2006, 450.

55 A. Van Oevelen, G. Jocqué, C. Persyn en B. De Temmerman, 'Overzicht van rechtspraak. Schade en schadeloosstelling', I003-I004, nr. 2 I.

56 O.a. Cass. 26 maart 2002, Arr.Cass. 2002, 875; Cass. I6 december 2004, Pas. 2004, I, 20I4; Cass. 20 februari 2006, Pas. 2006, 4I3. Het Hof van Cassatie toetst niettemin of de rechter het begrip schade niet heeft miskend (bijv. Cass. 20 februari 2006, Pas. 2006, 4I3) en of de door de rechter vastgestelde feiten voldoende grondslag opleveren voor de gevolgtrekkingen die de rechter daaruit in rechte maakt (Cass. 4 maart 1999, Arr.Cass. I999, 314).

Cass. II september 2009, NJW 2010, 25, noot GJ. 
bestanddelen. ${ }^{8}$ Hoewel de tabel niet bindend is, is zijn invloed op de praktijk erg groot. Steeds vaker rechtvaardigen rechters het toegekende bedrag door verwijzing naar de Indicatieve Tabel of naar de normen van de 'gebruikelijke rechtspraak'. ${ }^{5}$ Hierdoor wordt de begroting steeds meer gestandaardiseerd. Het Hof van Cassatie heeft recent zijn zegen gegeven aan het gebruik van de Indicatieve Tabel wanneer er geen aanwijzingen zijn dat de toestand van de schadelijder bijzonder of abnormaal is. ${ }^{60}$ Specifiek op het terrein van de schade bij weerkaatsing, is de Indicatieve Tabel een belangrijk instrument geworden bij de begroting van morele schade van nabestaanden. ${ }^{6 r}$

I2. Tot slot is, anders dan in het Nederlandse ${ }^{62}$ en het Duitse Burgerlijk Wetboek ${ }^{63}$, in ons Burgerlijk Wetboek geen limitatieve opsomming opgenomen van derden aan wie en de schadesoorten waarvoor vergoeding verschuldigd is bij letsel of overlijden.

I3. Het Belgische recht laat dus geen enkele a priori-beperking van de mogelijke aanspraken toe. ${ }^{64}$ De ruime regel van artikel 1382 BW erkent de aanspraak van elke persoon die met voldoende zekerheid kan aantonen dat hij schade heeft geleden als gevolg van de onrechtmatige daad. Dit principe gaat terug op een oude traditie ${ }^{65}$ en wordt beschouwd als een van de wezenskenmerken van het Belgische aansprakelijkheidsrecht.

Het niet a priori afbakenen van de kring van mogelijke aanspraakgerechtigden is nochtans geen evidente keuze. ${ }^{66}$ Dat blijkt uit het feit dat vele andere rechtsstelsels regels hanteren die tot doel hebben deze kring wel van meet af aan te begrenzen, bijvoorbeeld door toepassing te maken van de leer van de relatieve onrechtmatige daad en van een causaliteitsleer die een verdere selectie van feitelijke oorzaken toelaat, zoals de leer van de adequate oorzaak. ${ }^{67}$ De DCFR tracht tegemoet te komen aan de

58 De eerste versie verscheen in I995. Inmiddels is de tabel aan zijn vijfde versie toe: Indicatieve Tabel 2008 (NJW 2008, 710-72I). Zie G. Jocqué, 'De nieuwe indicatieve tabel kritisch bekeken', RW 2008-09, III4-II22; T. Vansweevelt en B. Weyts, Buitencontractueel Aansprakelijkheidsrecht, 693697, nr. 1087-I092.

59 Zie de rechtspraak aangehaald bij D. De Callataÿ en N. Estienne, Chronique de jurisprudence. Le dommage, I7-I8; A. Van Oevelen, G. Jocqué, C. Persyn en B. De Temmerman, 'Overzicht van rechtspraak. Schade en schadeloosstelling', roı6.

60 Cass. II september 2009, NJW 2010, 25, noot GJ.

6r Zie infra nr. 33 .

62 Art. 6:107-6:108 BW. Zie hierover het Nederlandse preadvies van E. Engelhard.

63 Par. 844-845 BGB. Zie I. Boone, Verhaal van derde-betalers op de aansprakelijke, Antwerpen, Intersentia, 2009 (hierna verkort Verhaal van derde-betalers), 428, nr. 438, en de literatuurverwijzingen aldaar; C. Van Dam, European Tort Law, 326-327 en 329.

64 E. Dirix, Het begrip schade, 93-94, nr. I36; J. Ronse, L. De Wilde, A. Claeys en I. Mallems, Schade, 98-IOo, nr. I25-I28.

65 Zie o.a. G. Beltjens, Encyclopédie du droit civil belge, t.III, Luik, I892, 27, nr. 37; F. Laurent, Principes de droit civil, t.XX, Brussel, Bruylant, I878, 572, nr. 528 en 578, nr. 534. Voor uitvoerige verwijzingen en citaten, zie D. De Marez, Afgeleide schade van aandeelhouders, 207-2I2, nr. 239-244.

66 Zie ook D. De Marez, Afgeleide schade van aandeelhouders, 2I3, nr. 245.

67 Zie W.V.H. Rogers, J. Spier en G. Viney, 'Preliminary observations', in J. Spier (ed.), The limits of liability. Keeping the floodgates shut, Kluwer Law International, Den Haag, I996, I-I5; W. Van Gerven, J. Lever, P. Larouche, C. von Bar en G. Viney, Tort Law. Scope of Protection, Common Law of Europe Casebooks, Oxford, Hart Publishing, I998, 493 p. 
zorg voor inperking van de aansprakelijkheid, onder meer door het begrip 'legally relevant damage' in te voeren (VI.-2:IOI). ${ }^{68}$ In de eerste plaats is er sprake van juridisch relevante schade wanneer het gaat om een schadesoort die specifiek geregeld is in een van de daarop volgende bepalingen. ${ }^{69}$ In de tweede plaats kan juridisch relevante schade ook voortvloeien uit de inbreuk op een recht of de krenking van een beschermwaardig belang, op voorwaarde dat het redelijk en billijk is om aan de eiser een recht op vergoeding toe te kennen. Om dit te beoordelen is een belangenafweging onvermijdelijk..$^{\circ}$ De DCFR geeft een aantal criteria die de rechter in die afweging kan betrekken, ${ }^{71}$ namelijk de grondslag van de aansprakelijkheid,,$^{72}$ de aard van de schade en haar afstand tot de onrechtmatige daad,73 de redelijke verwachtingen van de schadelijder ${ }^{74}$ en beleidsoverwegingen met betrekking tot het algemeen belang en de interne coherentie van het privaatrecht. ${ }^{75}$

I4. Hierna gaan we na tot welke resultaten de toepassing van het Belgische aansprakelijkheidsrecht leidt voor bepaalde categorieën van schadelijders bij weerkaatsing. Worden er, ondanks het erg slachtoffervriendelijke uitgangspunt, toch grenzen gesteld aan de vergoeding voor weerkaatste schade van derden?

68 Zie voor nadere toelichting: Principles DCFR, Vol. 4, 3I39-3I5I.

69 Zo maken bijvoorbeeld kosten voor medische zorgen krachtens VI.-2:20I(2)(a) en begrafeniskosten krachtens VI.-2:202 (2)(b) juridisch relevante schade uit.

70 Principles DCFR, Vol. 4, 3I45.

7 I VI.-2:202(3) DCFR.

72 'The ground of accountability'. Blijkens de toelichting wordt hiermee bedoeld dat rekening gehouden kan worden met de aard van het gedrag dat de schade heeft veroorzaakt. Zo zal sommige schade alleen juridisch relevant zijn wanneer ze opzettelijk is veroorzaakt (Principles DCFR, Vol. 4, 3146).

73 'The nature and proximity of the damage'. Met betrekking tot 'the nature of the damage' zegt de toelichting dat er bepaalde soorten nadelen zijn die men moet ondergaan zonder dat zij tot vergoeding aanleiding kunnen geven. Het gaat bijvoorbeeld om de aantasting van de levenskwaliteit die de bewoners van een bepaalde regio moeten ondergaan als gevolg van een industrieel ongeval waardoor zij niet meer kunnen genieten van de specifieke fauna en flora die aangetast is door de vervuiling (Principles DCFR, Vol. 4, 3I46). Het 'proximity'-criterium houdt verband met de lengte van de causale keten tussen de onrechtmatige daad en de schade. De toelichting geeft o.m. het voorbeeld van een persoon die een concert organiseert met een zanger over wiens privéleven in de pers onjuiste berichten zijn verschenen waardoor er voor het concert minder publiek opdaagt dan in normale omstandigheden het geval zou zijn. Deze schade is 'too remote and consequently not legally relevant in terms of liability' (Principles DCFR, Vol. 4, 3147).

74 'The reasonable expectations of the person who suffers or would suffer the damage'. Volgens de toelichting moet dit criterium in verband gebracht worden met het verlies van een kans, waar het toekennen van een volledige vergoeding even onbillijk zou zijn als het toekennen van in geheel geen vergoeding (Principles DCFR, Vol. 4, 3I47-3I48).

75 'Considerations of public policy'. Blijkens de toelichting worden hieronder verstaan beleidsoordelen met betrekking tot het algemeen belang en de interne coherentie van het privaatrecht. Ook dergelijke overwegingen kunnen een rol spelen bij de beoordeling van het bestaan van juridisch relevante schade. Zo is bijvoorbeeld de tijd die een persoon B moet besteden aan het voeren van verweer ten aanzien van een manifest ongegronde vordering van A geen juridisch relevante schade, omdat er anders over oordelen A's recht op toegang tot de rechter in het gedrang zou brengen (Principles DCFR, Vol. 4, 3I48). 


\section{Schade van naasten en nabestaanden}

\section{I Inleiding}

I5. Onder schade van naasten en nabestaanden begrijpen wij, zoals gebruikelijk is in België, de schade van personen die een nauwe persoonlijke band (meestal een gezinsband of nauwe familieband) met het slachtoffer hebben en die voor hen voortvloeit uit de persoonsschade van het slachtoffer. Daarbij wordt een onderscheid gemaakt naargelang de schade gereflecteerd is door de letsels of door het overlijden van het slachtoffer en naargelang de schadesoort. Relevante schadesoorten voor de naasten en nabestaanden zijn morele schade (ook affectieschade of genegenheidsschade genoemd), schade wegens het verlies van het voordeel dat de naaste of nabestaande haalde uit het beroepsinkomen van het slachtoffer, schade door gemaakte kosten en schade door het verlenen van hulp. In de bespreking hierna ligt de nadruk op de vraag welke personen als aanspraakgerechtigden worden beschouwd. Het preadvies is niet de geschikte plaats om in te gaan op erg technische aspecten in verband met de vaststelling van de omvang van de schade (bijvoorbeeld bij inkomensverlies na overlijden).

\subsection{Schade van naasten bij letselschade}

\subsubsection{Morele schade}

I6. Naasten kunnen genegenheidsschade lijden als gevolg van de letsels van het slachtoffer. Zij ondergaan immers een eigen leed door het zien lijden van het slachtoffer. ${ }^{76}$ Deze schade komt voor vergoeding in aanmerking. ${ }^{77}$ In een arrest van 20 februari 2006 heeft het Hof van Cassatie nog bevestigd dat het morele leed dat een echtgenoot ondergaat ten gevolge van de letsels aan de andere echtgenoot het voorwerp kan uitmaken van een vordering tot schadevergoeding, ook wanneer de psychische druk ten gevolge van dat lijden de normale bijstand van de echtgenoot niet te boven gaat. ${ }^{8}$ Eerder had het Hof al geoordeeld dat het causaal verband tussen de onrechtmatige daad en het leed van de ouders bij het zien lijden van hun kind niet kan worden ontkend op de enkele grond dat zodanig leed tot de normale beleving van het ouderschap behoort. ${ }^{79}$

76 D. De Callataÿ en N. Estienne, Chronique de jurisprudence. Le dommage, 275 e.v.; A. Van Oevelen, G. Jocqué, C. Persyn en B. De Temmerman, 'Overzicht van rechtspraak. Schade en schadeloosstelling', I2II.

77 L. Cornelis, 'Actuele tendensen bij de vergoeding van morele schade', in J.-L. Fagnart en A. Pire, Problèmes actuels de la réparation du dommage corporel, Brussel, Bruylant, I993, (Iog) II4 ; D. Simoens, 282 , nr. I45.

78 NJW 2006, 798, noot IB.

79 Cass. 3 februari ig87, Arr.Cass. I986-87, 724 en RW I987-88, 220. 
Ook de DCFR erkent de niet-economische schade die een persoon ondervindt als gevolg van de letsels van een persoon met wie hij op het ogenblik van het schadegeval een erg nauwe persoonlijke band heeft, als een vergoedbare schade. ${ }^{80}$

17. Niettemin tonen de Belgische feitenrechters zich veeleer terughoudend om het bestaan van genegenheidsschade bij letsels te erkennen. Vaak wordt deze schade alleen aanvaard wanneer het slachtoffer uitzonderlijke pijn doorstaat of de toestand erg zorgwekkend is, bijvoorbeeld wanneer het slachtoffer in levensgevaar of in coma verkeert $^{81}$ of bij ernstige blijvende invaliditeit. ${ }^{82,83}$ In de gevallen waarin de rechter het bestaan van genegenheidsschade van naasten bij letsels van het rechtstreekse slachtoffer aanvaardt, gebeurt dat bovendien enkel voor een zeer beperkte kring van naasten, doorgaans alleen de echtgenoot en/of de ouders van het slachtoffer. ${ }^{84}$

De toegekende bedragen zijn zeer uiteenlopend en worden meestal ex aequo et bono vastgesteld. ${ }^{85} \mathrm{Zij}$ kunnen ook hoger liggen dan het bedrag van morele schade bij overlijden. De politierechtbank van Verviers kende bijvoorbeeld aan elke ouder een bedrag van 25.000 euro toe als vergoeding voor de genegenheidsschade, omdat zij dagelijks de fysieke en mentale aftakeling van hun zoon ten gevolge van een ongeval meemaken, er hun levenswijze moeten aan aanpassen en zich onvermijdelijk zorgen maken over de toekomst van hun kind. ${ }^{86}$

80 VI.-2:202 (I) DCFR: 'Non economic loss caused to a natural person as a result of another's personal injury or death is legally relevant damage if at the time of injury that person is in a particularly close relationship to the injured person'.

8I Bijv. Pol. Mechelen 8 december 2003, DeVerz. 2004, 837; Zie voor meer rechtspraak: D. De Callatä̈ en N. Estienne, Chronique de jurisprudence. Le dommage, 276-282; A. Van Oevelen, G. Jocqué, C. Persyn en B. De Temmerman, 'Overzicht van rechtspraak. Schade en schadeloosstelling', I2I $2-\mathrm{I} 2 \mathrm{I} 3$.

82 Bijv. Pol. Gent 29 september 2003, RW 2005-06, I235.

83 De Indicatieve Tabel stelt gelijksoortige vereisten en vermeldt bovendien dat 'deze vergoeding wordt toegekend vanaf het moment dat de familieband niet meer normaal kan worden beleefd'. Zie kritisch daarover: G. Jocqué, 'De nieuwe indicatieve kritisch bekeken', RW 2008-o9, (III4) II 20: de auteur wijst erop dat de genegenheidsschade van naasten weliswaar bepaald wordt door de band met het rechtstreekse slachtoffer, maar dat de beleving van deze band ook in pijnlijke omstandigheden onaangetast kan blijven.

84 Bijv. Gent 30 juni 1998, De Verz. I999, 274: genegenheidsschade van de ouders en de echtgenoot van het slachtoffer dat drie dagen in coma en levensgevaar verkeerde; Pol. Verviers II maart 2008, VAV 2008, 342: genegenheidsschade van de ouders wegens het zien lijden van hun I9-jarige dochter die het slachtoffer was van een verkeersongeval. Vgl. Pol. Verviers 6 november 2007, VAV 2009, 2I4: naast een vergoeding van 20.000 euro voor de genegenheidsschade van de ouders van een jongeman die zwaar gehandicapt is ten gevolge van een ongeval, wordt aan de tweelingbroer die met het slachtoffer samenwoont een vergoeding van 7.500 euro voor zijn genegenheidsschade toegekend.

85 D. De Callataÿ en N. Estienne vermelden bedragen tussen 5.000 BEF en 75.000 euro (Chronique de jurisprudence. Le dommage, 277-28I).

86 Pol. Verviers 5 maart 2008, T.Pol. 2008, 222. Vgl. Pol. Neufchâteau 20 april 2006, De Verz. 2007, 338, noot J. Muyldermans en RGAR 2008, nr. I4394: 20.000 euro voor elk van de ouders van een zwaar gehandicapt kind, waarbij de rechtbank erop wijst dat de schade die voortvloeit uit het zien lijden van een dierbare verschilt van die welke uit het verlies ervan voortvloeit; de ouders van een zwaar gehandicapt kind kunnen geen rust vinden omdat ze geconfronteerd worden met het onomkeerbare lijden van hun kind. 
I8. De lichamelijke schade van het rechtstreekse slachtoffer kan voor de partner van dat slachtoffer ook een eigen seksuele schade bij weerkaatsing meebrengen, doordat hij ingevolge de lichamelijke schade van zijn partner evenmin of minder seksuele bevrediging kan vinden. ${ }^{87}$ Deze schade wordt als een morele schade beschouwd, al gaat het wel om een specifieke vorm van morele schade die te onderscheiden is van de eigenlijke genegenheidsschade. ${ }^{88}$

\subsubsection{Verlies van het voordeel uit het beroepsinkomen van het slachtoffer}

I9. Men zou kunnen zeggen dat naasten van het slachtoffer die voordeel haalden uit diens beroepsinkomen, zoals zijn echtgenoot, samenwonende partner of kinderen, (afgeleide) schade lijden wanneer het slachtoffer na een ongeval geheel of gedeeltelijk arbeidsongeschikt wordt en daardoor niet of minder kan bijdragen aan het gezinsbudget. Toch hebben gezinsleden van het slachtoffer dat arbeidsongeschikt is geworden, geen recht op vergoeding voor inkomensverlies. Dit verlies wordt immers beschouwd als schade van het rechtstreekse slachtoffer. ${ }^{89}$ De schadevergoeding voor inkomensverlies verschaft aan het slachtoffer een vervangingsinkomen waarmee het kan bijdragen tot het onderhoud van partner en kinderen. Wanneer het door het slachtoffer geleden inkomensverlies wordt vergoed, verdwijnt dus tegelijk het mogelijke nadeel voortvloeiend uit dat inkomensverlies voor zijn gezinsleden. ${ }^{\circ}$

Ook de DCFR gaat ervan uit dat inkomensverlies bij letsel een eigen schade van het slachtoffer uitmaakt; derden kunnen alleen vergoed worden voor 'verlies aan onderhoud' bij overlijden van het slachtoffer..$^{\text {I }}$

\subsubsection{Schade door gemaakte kosten}

20. De letsels van het slachtoffer brengen allerlei kosten met zich, waarvoor het niet altijd eenvoudig is te bepalen of zij schade uitmaken van het slachtoffer zelf of van de naasten die deze kosten voor hun rekening nemen.

2I. De letsels van het slachtoffer kunnen tot gevolg hebben dat het zich niet meer op eigen kracht kan verplaatsen naar bijvoorbeeld de behandelende geneesheer of naar het ziekenhuis en hiervoor een beroep doet op zijn naasten. Het staat buiten kijf dat

87 B. De Temmerman, 'De vergoeding van seksuele schade', RW I997-98, (Ioor) Ioo5; zie ook Indicatieve Tabel 2008, nr. 39 (NJW 2008, 7I5).

88 T. Vansweevelt en B. Weyts, Buitencontractueel Aansprakelijkheidsrecht, 725, nrs. II35-II36.

89 E. Dirix, Het begrip schade, 66, nr. 92; D. Simoens, Schade en schadeloosstelling, I27 e.v.; A. Van Oevelen, G. Jocqué, C. Persyn en B. De Temmerman, 'Overzicht van rechtspraak. Schade en schadeloosstelling', II54, nr. 43 .

90 Opmerkelijk is wel dat volgens (bekritiseerde) cassatierechtspraak, hoewel de beroepsinkomsten van iemand die onder het wettelijk stelsel is gehuwd tot het gemeenschappelijk vermogen behoren, de vergoeding voor schade ingevolge arbeidsongeschiktheid tot het eigen vermogen van het getroffen slachtoffer en dus niet tot de huwgemeenschap behoort (Cass. 8 april I994, Arr. Cass. I994, 35I en R.Cass. I994, 227, noot A. Verbeke; Cass. I4 november 2000, Arr.Cass. 2000, I783 en AJT 200I-2002, 623, noot F. Logghe).

9I Zie VI.- 2:202 (2) (b) DCFR en de toelichting in Principles DCFR, Vol. 4, 3226. 
de aansprakelijke de kosten voor deze verplaatsingen moet vergoeden. ${ }^{92}$ Alleen kan men zich de vraag stellen wie er gerechtigd is op vergoeding: het slachtoffer zelf of de naasten die de kosten hebben gemaakt. Is de schade wegens de gedane verplaatsingskosten naar deze laatsten verplaatst? In de regel worden deze kosten vergoed aan het slachtoffer zelf. ${ }^{93}$ De nood om zich te (laten) verplaatsen is een schade die het slachtoffer zelf ondergaat. Het bestaan van deze schade wordt dus geabstraheerd van de feitelijke omstandigheid dat derden voor de verplaatsingen hebben gezorgd.

Wanneer het slachtoffer in het ziekenhuis verblijft, kunnen zijn naasten verplaatsingskosten maken om hem te bezoeken. Voor deze verplaatsingskosten kan er geen twijfel bestaan dat zij schade van de naasten uitmaken. ${ }^{94}$ Niettemin kennen sommige rechters de vergoeding voor verplaatsingen van een naaste voor het bezoek aan het slachtoffer in het ziekenhuis aan het slachtoffer zelf toe, ${ }^{95}$ soms met het argument dat deze kosten in het belang van die laatste zijn verricht.

22. De kosten van medische zorgen vormen een persoonlijke schade van het slachtoffer, niet van de naasten die deze kosten ten laste nemen. Volgens het Hof van Cassatie doet de omstandigheid dat de ouders op grond van hun wettelijke onderhoudsplich $t^{96}$ de kosten voor de medische zorgen van hun minderjarig kind voor hun rekening dienen te nemen, geen afbreuk aan het recht van het kind op vergoeding voor deze kosten. ${ }^{97}$ Toch wordt soms geoordeeld dat de ouders, handelend voor hun huwgemeenschap, gerechtigd zijn op vergoeding van de kosten die zij ten laste hebben genomen..$^{8}$

Ook de DCFR beschouwt de kosten voor medische zorgen als een vergoedbare schade van het slachtoffer zelf. ${ }^{99}$

23. Wanneer het ongeval tot het verlies van een schooljaar heeft geleid, kan dit naast economische en morele schade voor de scholier of student, ook extra uitgaven teweegbrengen bij degene die voor de opvoeding van het slachtoffer instaat. De

92 D. Simoens, Schade en schadeloosstelling, 247, nr. I28; A. Van Oevelen, G. Jocqué, C. Persyn en B. De Temmerman, 'Overzicht van rechtspraak. Schade en schadeloosstelling', I3II-I3I2, nr. 57.I.

93 Bijv. Pol. Nijvel 2 januari I996, RGAR I999, nr. I3.055: de nood om zich te (laten) verplaatsen is schade van het slachtoffer zelf, dat desgevallend op zijn beurt deze kosten moet vergoeden aan de verwanten die voor het vervoer hebben gezorgd. Zie D. De Callataÿ en N. Estienne, Chronique de jurisprudence. Le dommage, 330.

94 Cass. I3 september 2000, Arr.Cass. 2000, I346, JT 200I, I04 en RW 200I-02, II33: de beslissing waarbij de rechter aan het slachtoffer, dat zich als enige burgerlijke partij had gesteld, vergoeding toekent voor de verplaatsingskosten van zijn naasten tijdens zijn ziekenhuisopname, is niet naar recht verantwoord aangezien het geen persoonlijke schade van het slachtoffer betreft.

95 Rb. Brussel I7 november I999 en Brussel 2 oktober 2002, De Verz. 2003, 397; Pol. Nijvel 7 juni 2004, RGAR 2006, nr. I4096.

96 Art. 203 BW.

97 Cass. I2 januari 2004, RW 2005-06, noot B. Weyts: het ziekenfonds, dat voor de verstrekte ziektekostenprestaties gesubrogeerd is in de rechten van het minderjarige kind (art. 136, par. 2, vierde lid Ziektewet), kan dan ook voor deze prestaties verhaal uitoefenen op de vader die aansprakelijk is voor de letsels van zijn kind. Zie over deze problematiek: I. Boone, Verhaal van derde-betalers, 566, nr. 597 en 594-608, nr. 624-640.

98 Pol. Gent 7 januari 2004, De Verz. 2004, 855; A. Van Oevelen, G. Jocqué, C. Persyn en B. De Temmerman, 'Overzicht van rechtspraak. Schade en schadeloosstelling', nr. 55.4.

99 VI.-2:20I (I) en (2) (a). DCFR. 
politierechtbank te Verviers was van oordeel dat de ouders niet gerechtigd zijn op vergoeding voor materiële schade bij weerslag wegens het verlies van een schooljaar van hun I9-jarige dochter, 'gelet op de wettelijke plicht tot onderhoud, opvoeding en opleiding van de ouders, die een eigen rechtsgrond vormt'. ${ }^{100}$ Dit antwoord is betwistbaar, gezien het Hof van Cassatie sinds 200I niet meer aanvaardt dat het bestaan van een wettelijke plicht het causaal verband met de onrechtmatige daad verbreekt, maar stelt dat uitgaven gedaan ter uitvoering van een wettelijke plicht een vergoedbare schade kunnen uitmaken behoudens wanneer uit de strekking of de inhoud van de wet blijkt dat die uitgaven definitief voor rekening moeten blijven van degene die ze gedaan heeft. ${ }^{\text {10r }}$ Doorgaans wordt aangenomen dat de ouders wel gerechtigd zijn op vergoeding voor de kosten die zij hebben moeten dragen als gevolg van het verlies van een school- of studiejaar. ${ }^{102}$ Omdat deze kosten vaak moeilijk te bewijzen zijn, stelt de Indicatieve Tabel forfaitaire bedragen voor. ${ }^{103}$

\subsubsection{Schade door hulp aan het slachtoffer}

24. Ernstige letsels brengen vaak mee dat het slachtoffer tijdelijk of blijvend hulp van derden nodig heeft om zich in het dagelijkse leven te kunnen beredderen. Wanneer naasten de zorg op zich nemen van het gekwetste slachtoffer, is onduidelijk wie nu precies schade lijdt: de naaste die de hulp verleent of het slachtoffer dat nood heeft aan de hulp van derden. Net als de verplaatsingskosten en de medische kosten betaald door naasten van het slachtoffer, raakt dit geval de problematiek van de verplaatste schade. Brengen de inspanningen van de naaste een verplaatsing van schade mee waardoor niet langer het slachtoffer zelf, maar de hulpverlenende naaste aanspraak kan maken op vergoeding? ${ }^{104}$

25. In België is de belangstelling voor deze vraag aangezwengeld door het cassatiearrest van 6 november 200I (ook wel gekend als het 'grootouderarrest'). ${ }^{105} \mathrm{Nadat}$ hun dochter door de fout van een derde bij een ongeval om het leven was gekomen, hadden grootouders hun toen 8-jarige kleinzoon, wiens vader onbekend was, bij zich opgenomen. Zij vorderden van de aansprakelijke schadevergoeding voor meerinspanningen die zij hadden geleverd voor de verzorging en de opvoeding van hun

Ioo Pol. Verviers II maart 2008, VAV 2008, 342.

IoI Infra nr. 48 .

I02 Bijv. Antwerpen I4 december 2005, VAV 2006, 72I; zie A. Van Oevelen, G. Jocqué, C. Persyn en B. De Temmerman, 'Overzicht van rechtspraak. Schade en schadeloosstelling', IIg6-II97, nr. 46.3 .

I03 Voor de kosten van een verloren schooljaar in het lager onderwijs, stelt de tabel een vergoeding voor van 390 euro, in het middelbaar onderwijs I.000 euro, in het hoger onderwijs 4.300 euro (indien de student 'op kot' verblijft) of 2.500 euro (indien de student niet 'op kot' gaat). Universitair onderwijs wordt verondersteld goedkoper te zijn. Hiervoor bedragen de voorgestelde vergoedingen resp. 4.000 en 2.000 euro (naargelang de student al dan niet 'op kot' gaat).

I04 Zie I. Boone, 'Schadevergoeding voor vrijwillige prestaties', NJW 2006, 740-746; B. De Temmerman, 'Recente cassatierechtspraak inzake schade en schadeloosstelling (200I-2006)', RGAR 2003, nr. $13763,4-6$.

I05 Cass. 6 november 200I, Arr.Cass. 200I, I856, concl. J. Du Jardin, RW 200I-02, I466, concl. J. Du Jardin. Zie ook infra nr. 42. 
kleinkind. Het Hof van Cassatie besliste dat degene die op vrijwillige basis prestaties verricht, gerechtigd is op schadevergoeding voor zover hij daardoor schade lijdt. Dit is volgens het Hof het geval wanneer deze prestaties op redelijke gronden worden verricht ten behoeve van de benadeelde, teneinde bij deze de schadelijke gevolgen van de door de derde begane fout te lenigen, en wanneer het niet in de bedoeling van de verstrekker van de prestaties ligt om de last ervan definitief voor zijn rekening te nemen. ${ }^{106}$ In het grootouderarrest ging het om hulp aan een nabestaande na het overlijden van het rechtstreekse slachtoffer. De regel van het arrest is echter zodanig geformuleerd dat hij ook toepassing zou kunnen vinden bij letselschade, meer bepaald de schade die voortvloeit uit de hulp van derden die het rechtstreekse slachtoffer als gevolg van zijn letsels nodig heeft. De conclusie zou dan zijn dat niet het slachtoffer, maar de hulpverlenende naaste schade lijdt. ${ }^{107}$ Het grootouderarrest heeft echter niet gezorgd voor een omwenteling in de rechtspraktijk die de schade ingevolge de noodzaak een beroep te moeten doen op hulp door derden sinds lang ${ }^{108}$ en ook vandaag nog beschouwt als een schade van het slachtoffer zelf, zelfs wanneer de hulp geleverd wordt door een familielid. ${ }^{\text {I09 }}$ Soms wordt daarbij gewezen op het feit dat het slachtoffer in de toekomst misschien niet altijd op de hulp van een naaste zal kunnen rekenen. ${ }^{\text {Iо }}$ Toch komt het voor dat de vergoeding die het slachtoffer vordert voor deze hulp geweigerd wordt omdat zij doublure uitmaakt met de vergoeding die aan de hulpverlenende naaste is toegekend. ${ }^{\text {III }}$

26. De benadering van de meerderheid van de rechtspraak, die de vergoeding voor hulp van derden aan het slachtoffer toekent, stemt overeen met de modelregel voorgesteld in de DCFR: de kosten voor medische zorgen, met inbegrip van de redelijke kosten voor de zorg van het slachtoffer door zijn of haar naasten, worden er

Io6 Het Hof heeft dezelfde regel toegepast op een geval waarin de staat vrijwillig medische kosten had betaald ten behoeve van een militair die gewond werd bij een ongeval (Cass. 4 maart 2002, JLMB 2004, noot J. Wildemeersch).

I07 I. Boone, 'Schadevergoeding voor vrijwillige prestaties', NJW 2006, (740) 745-746; B. De Temmerman, 'Recente cassatierechtspraak inzake schade en schadeloosstelling (200I-2006), RGAR 2003 , nr. 13763 , 5. Beide auteurs wijzen erop dat deze benadering problemen doet rijzen, onder meer betrekking tot de vergoeding van toekomstige schade (infra nr. 43).

Io8 Zie het principearrest van 30 november 1977 (Arr.Cass. I978, 368). Een hof van beroep had geweigerd vergoeding voor hulp van derden toe te kennen, omdat het slachtoffer door zijn echtgenote werd verzorgd. Het Hof van Cassatie aanvaardt dat het feit genoodzaakt te zijn een beroep te doen op de hulp van een derde persoon, op zichzelf een materiële schade oplevert voor het slachtoffer van een ongeval en dat de hulp verleend door de echtgenote van het slachtoffer niet in aanmerking kan worden genomen bij de beoordeling van de omvang van de vergoeding. Zie ook D. Simoens, Schade en schadeloosstelling, 238 , nr. I25.

Io9 O.m. Brussel I6 oktober 2006, RGAR 2008, nr. I4.432; Rb. Brussel 28 april 2009, RGAR 20I0, nr. I4.594; Pol. Luik 20 januari 2004, RGAR 2006, nr. I4069; Pol. Brussel I5 december 2004, RGAR 2006, nr. I4.IIo; Pol. Brugge 6 september 2007, RW 2008-09, I6I5; Pol. Spa 8 januari 2008, VAV 2008, 448. Zie ook A. Van Oevelen, G. Jocqué, C. Persyn en B. De Temmerman, 'Overzicht van rechtspraak. Schade en schadeloosstelling', 945, nr. I en II77, nr. 44.5.b.

IIO Rb. Verviers 6 november 2007, VAV 2009, 2I4: het slachtoffer, een jongeman die ernstig gehandicapt was ten gevolge van ongeval, had tot dan toe kunnen rekenen op de hulp van zijn moeder, maar die was inmiddels een dagje ouder geworden.

III Rb. Brussel II januari 2000, RGAR 200I, nr. I3.43I en 2002, nr. I3.500: aan elk van de ouders werd een ex aequo et bono-vergoeding van 150.000 BEF toegekend. 
beschouwd als een schade van het slachtoffer zelf. ${ }^{\text {II2 }}$ Volgens de toelichting is het slachtoffer aan wie de vergoeding voor deze kosten wordt toegekend er dan wel toe gehouden op zijn beurt de naasten te vergoeden op grond van bijvoorbeeld zaakwaarneming of ongerechtvaardigde verrijking. ${ }^{\text {I13 }}$

27. Gaat men ervan uit dat het slachtoffer aanspraak kan maken op vergoeding voor hulp van derden, ook wanneer de hulp verstrekt wordt door een naaste, dan is het nog de vraag of die vrijwillige hulp een gegeven is waarmee rekening moet worden gehouden bij het bepalen van de omvang van de schadevergoeding waarop het slachtoffer gerechtigd is. In een arrest van 30 november 1977 had het Hof van Cassatie al geoordeeld dat de hulp verleend door de echtgenote van het slachtoffer niet in aanmerking kan worden genomen bij de beoordeling van de omvang van de vergoeding. ${ }^{14}$ De vraag werd onlangs opnieuw voorgelegd aan het Hof. ${ }^{\text {II }}$ Een jonge vrouw die als gevolg van een ongeval veroorzaakt door de fout van een derde aan een spastische tetraplegie lijdt, heeft nood aan ruim i8 uur per dag hulp van derden. Tot nog toe woont zij in bij haar ouders, die vrijwel alle taken op zich nemen. De rechtbank kent een vergoeding toe berekend op basis van de kostprijs voor betaalde hulp. De omstandigheid dat het slachtoffer een beroep kan doen op kosteloze hulp van familieleden, belet volgens de rechtbank niet dat zij gerechtigd is aanspraak te maken op dezelfde vergoeding als wanneer zij exclusief een beroep zou doen op betaalde hulp. De aansprakelijke voert voor het Hof van Cassatie aan dat de vergoeding voor hulp van derden bepaald moet worden aan de hand van de concrete feitelijke gegevens. Omdat in casu de hulp van derden die het slachtoffer nodig heeft, gratis verstrekt wordt door familie, kan de vergoeding volgens hem niet bepaald worden in functie van professionele hulp tegen betaling. Het Hof van Cassatie bevestigt evenwel de beslissing van de rechtbank:

'In het geval het slachtoffer gerechtigd is beroep te doen op professionele betaalde hulp, kan die materiële schade door de rechter geraamd worden op het bedrag dat voor die hulp verschuldigd is, ook indien het slachtoffer op deze betalende hulp geen beroep heeft gedaan'.

II2 VI.-2:20I (2) DCFR.

II3 Principles DCFR, Vol. 4, 3199. Naar Belgisch recht is het echter niet eenvoudig om een rechtsgrond aan te duiden op grond waarvan het slachtoffer verplicht kan worden om de hulpverlenende verwant te vergoeden. Bij vrijwillige prestaties aan een familielid of vriend stuit zaakwaarneming immers vaak op het vereiste dat het optreden van de zaakwaarnemer noodzakelijk moet zijn. Die noodzaak is er bijvoorbeeld niet wanneer het slachtoffer over voldoende financiële middelen beschikt om professionele hulp te betalen. Ook de vordering op grond van ongerechtvaardigde verrijking wordt in familierelaties zelden ingewilligd, omdat de eigen wil van het familielid de vermogensverschuiving zou rechtvaardigen (zie B. Wylleman, 'Vergoeding van prestaties voor familie of vrienden op basis van zaakwaarneming of vermogensverschuiving zonder oorzaak' (noot onder Brussel 3 juli 1996), AJT I996-97, 329-331).

II4 Cass. 30 november I977, Arr.Cass. I978, 368.

II5 Cass. 20 februari 2009, AR C.07.0305.N. 
Ook de begroting van de schade wegens hulp door derden wordt dus geabstraheerd van de concrete omstandigheid dat de hulp door een naaste wordt verleend. ${ }^{116}$ Dit valt te verantwoorden vanuit het principe dat de benadeelde de vrije beschikking heeft over de schadevergoeding: het bedrag van de schadevergoeding wordt niet beïnvloed door de wijze waarop de benadeelde dit besteedt of zal besteden. ${ }^{\mathrm{II}} \mathrm{Als}$ uitgangspunt moet gelden dat het slachtoffer recht heeft op vergoeding voor de nodige hulp van derden naar de geldende marktvoorwaarden. De vraag of het slachtoffer de hulp die het ontvangt van derden effectief moet betalen, dient buiten beschouwing te blijven. Het toegekende bedrag moet het slachtoffer immers in staat stellen de nodige hulp te verkrijgen, ook wanneer het op een bepaald moment geen 'gratis' hulp van naasten meer kan of wil ontvangen.

Men kan zich afvragen of de keuze voor een abstracte schadebegroting op basis van de kost voor professionele hulp impliceert dat die standaard ook als bovengrens van de vergoeding geldt. Wanneer men de nood aan hulp van derden, ongeacht wie de hulp daadwerkelijk verstrekt, als een persoonlijke schade van het slachtoffer beschouwt, is het verdedigbaar dat die schade eveneens begroot moet worden op basis van de kost voor professionele hulp naar de geldende marktvoorwaarden wanneer bijvoorbeeld de echtgenoot of een ouder van het slachtoffer een erg goed betaalde baan opgeeft om voor het slachtoffer te zorgen. Het eventuele inkomensverlies van de naaste heeft immers als zodanig geen invloed op de schade van het slachtoffer wegens de nood een beroep te moeten doen op derdenhulp. Voor het slachtoffer is de hulp die de naaste vrijwillig verleent (in de regel) 'gratis', ook wanneer die naaste daarvoor zijn werk laat staan.

28. De nood aan hulp van derden wordt doorgaans onderscheiden van de huishoudschade, dit is de verminderde mogelijkheid om huishoudelijke taken te vervullen. Ook met betrekking tot die laatste schadesoort kan er discussie bestaan of zij persoonlijk door het slachtoffer wordt geleden dan wel een gereflecteerde schade van de gezinsleden uitmaakt. Traditioneel beschouwt men de huishoudschade als een persoonlijke schade van het slachtoffer. ${ }^{118}$ Een cassatiearrest van 6 januari 2010 toont aan dat ook een andere benadering mogelijk is. ${ }^{19}$ Een rechter had aan het slachtoffer van een verkeersongeval een vergoeding toegekend voor de huishoudschade tijdens diens ziekenhuisopname. Daarbij had hij geoordeeld dat de ziekenhuisopname het slachtoffer, niet ten koste van hemzelf maar ten koste van zijn gezinsleden, had verhinderd om huishoudelijke klussen te klaren. Volgens het Hof van Cassatie is de beslissing om het slachtoffer te vergoeden voor huishoudschade niet naar recht verantwoord, aangezien de schadelijder alleen recht heeft op herstel van de schade die hij persoonlijk heeft geleden.

II6 E. Dirix, 'Abstracte en concrete schade', RW 2000-200I, (I329) I333.

II7 Dit principe werd door de wetgever bevestigd in artikel 83 van de wet van 25 juni 1992 op de landverzekeringsovereenkomst.

II8 Pol. Antwerpen 24 mei 2002, De Verz. 2004, 604, noot P. Graulus; D. Simoens, Schade en schadeloosstelling, 220, nr. II9.

II9 Cass. 6 januari 20I0, AR P.og.II52.F. 


\subsection{Schade van nabestaanden bij overlijden}

29. Het overlijden levert geen schade meer op voor het slachtoffer zelf, ${ }^{\mathrm{I20}}$ maar is de gebeurtenis bij uitstek die aanleiding geeft tot schade voor de nabestaanden.

\subsubsection{Morele schade}

30. In tegenstelling tot Nederland, waar een wetsvoorstel dat ertoe strekte om aan bepaalde naasten een aanspraak op vergoeding voor affectieschade te geven recent nog werd afgewezen, ${ }^{\mathrm{I} 2 \mathrm{I}}$ aanvaardt het Belgische recht principieel dat de nabestaanden (doorgaans naaste familie- en gezinsleden) van het overleden slachtoffer aanspraak kunnen maken op vergoeding voor hun morele schade. Volgens de traditionele omschrijving strekt de vordering tot vergoeding van morele schade ertoe de pijn, de smart of enig ander moreel leed te lenigen en de schade in die mate te herstellen. ${ }^{122}$ Deze omschrijving lokt verontwaardiging uit, omdat ze suggereert dat het leed van een naaste van het overleden slachtoffer door de schadevergoeding wordt hersteld. Correcter en van meer empathie getuigt de opvatting dat de vergoeding voor morele schade het gebeurde niet ongedaan maakt en slechts de erkenning van het bestaan en van de omvang van het ondergane leed tot doel kan hebben. ${ }^{123}$

3I. De DCFR erkent morele schade als gevolg van andermans overlijden als 'legally relevant damage' op voorwaarde dat er op het ogenblik van het schadegeval een bijzonder nauwe persoonlijke band bestond tussen het slachtoffer en de aanspraakgerechtigde. ${ }^{124}$ Volgens de opstellers van de DCFR zou het vandaag niet langer aanvaardbaar zijn de morele schade van deze naasten niet als juridisch relevante schade te beschouwen. Gerechtigd op vergoeding zijn alleen nauwe verwanten of andere personen die een bijzonder nauwe persoonlijke band hebben met het slachtoffer. Een gewone vriendschapsband of een nauwe professionele relatie is niet voldoende om aanspraak te kunnen maken op vergoeding voor morele schade. ${ }^{125}$

32. De kring van nabestaanden die volgens de Belgische rechtspraak aanspraak kan maken op vergoeding voor morele schade bij overlijden is eerder ruim. De Indicatieve Tabel vermeldt richtbedragen voor morele schade van de volgende nabestaanden: ${ }^{126}$

I20 De doodstrijd en het besef van een naderend einde kan voor het slachtoffer wel schade opleveren. De vergoeding voor deze schade wordt aan de erfgenamen als rechtsopvolgers toegekend (A. Van Oevelen, G. Jocqué, C. Persyn en B. De Temmerman, 'Overzicht van rechtspraak. Schade en schadeloosstelling', IIoo, nr. $37 \cdot 3$ en II5I, nr. 4I)

I2I Zie hierover het Nederlandse preadvies van E. Engelhard.

I22 O.a. Cass. Io oktober I972, Arr.Cass. I973, I46, RW I972-73, 7I8, JT I973, I63, noot A. Tunc; Cass. I3 oktober 1999, Arr.Cass. 1999, I255; Cass. 9 februari 2006, NJW 2006, 798, noot IB.

I23 A. Van Oevelen, G. Jocqué, C. Persyn en B. De Temmerman, 'Overzicht van rechtspraak. Schade en schadeloosstelling', nr. 37.

I24 VI.- 2:202 (I) DCFR.

I25 Principles DCFR, Vol. 4, 3225-3226.

I26 De Indicatieve Tabel vermeldt de lijst vanuit het perspectief van het slachtoffer (het slachtoffer is een ouder of een kind), terwijl wij de lijst van schadelijders bij weerkaatsing vermelden (bijv. de naaste is een kind van het overleden slachtoffer of een ouder). 
de echtgenoot/echtgenote van het slachtoffer (I2.500 euro), de levenspartner waarmee het slachtoffer samenwoonde (I2.500 euro), de verloofde (5.000 euro), de feitelijk gescheiden partner (3.750 euro), de kinderen (7.500 euro indien inwonend bij de overleden ouder, 3.750 euro indien niet-inwonend), de ouders (I2.500 euro elk voor het verlies van een inwonend kind; 5.000 euro voor het verlies van een zelfstandig wonend kind), de broer/zus (2.500 euro inwonend, I.500 euro niet-inwonend), de stiefzoon/stiefdochter (5.000 euro inwonend, 2.500 euro niet-inwonend), de stiefvader/stiefmoeder (5.000 euro inwonend, 2.500 euro niet-inwonend), het kleinkind (2.500 euro inwonend, I.250 euro niet-inwonend), de grootouders (2.500 euro inwonend, I.250 euro niet-inwonend), het schoonkind (I.750 euro inwonend, I.I50 euro niet-inwonend) en de schoonouders (I.750 euro inwonend, I.I50 euro nietinwonend).

Hoewel de lijstniet limitatief is, zijn rechters zeer terughoudend om een vergoeding voor morele schade toe te kennen aan andere naasten van het overleden slachtoffer, bijvoorbeeld aan een schoonbroer of schoonzus, oom of tante, neef of nicht, meteof petekind, achterkleinkind of aan vrienden van het slachtoffer. ${ }^{127}$ Meestal worden dergelijke vorderingen afgewezen wegens gebrek aan bewijs van een uitzonderlijke band of van bijzondere omstandigheden. ${ }^{28}$ De zekerheid van hun affectieschade wordt dus in vraag gesteld, terwijl het bestaan van een affectieve band bij de naaste familie van het slachtoffer feitelijk wordt vermoed. ${ }^{129}$ Wanneer er toch een vergoeding wordt toegekend aan verder verwijderde naasten van het slachtoffer, dan gaat het doorgaans om bescheiden bedragen. ${ }^{13^{\circ}}$ De uitspraak van het Brusselse hof van assisen over de burgerlijke vorderingen naar aanleiding van de geruchtmakende $\mathrm{MP}_{3}$-moord, is een in het oog springende uitzondering. ${ }^{\mathrm{I3}} \mathrm{Op}$ I2 april 2006 werd in de hal van het station Brussel Centraal tijdens het spitsuur een I7-jarige jongen doodgestoken door een andere jongere toen hij zijn $\mathrm{MP}_{3}$-speler niet wilde afgeven. De bevolking reageerde geschokt op de roofmoord, die aanleiding gaf tot een 'stille mars' tegen zinloos geweld. Naast een uitzonderlijk hoge vergoeding voor morele schade van de ouders en van de broer ${ }^{132}$ kende het hof van assisen ook een bedrag toe van 25.000 euro voor de morele schade van de vriend van het slachtoffer die getuige was van de moord. Aan elk van de ouders van de vriend werd een vergoeding voor morele schade toegekend van I.500 euro. Men kan zich afvragen of de toegekende

I27 Zie L. Cornelis, 'Actuele tendensen bij de vergoeding van morele schade', in J.-L. Fagnart en A. Pire, Problèmes actuels de la réparation du dommage corporel, Brussel, Bruylant, I993, (Io9) II4-II6; E. De Kezel, 'De vergoeding voor het verlies van een kind ten gevolge van een verkeersongeval', TPR r999, (579) 6ro; A. Van Oevelen, G. Jocqué, C. Persyn en B. De Temmerman, 'Overzicht van rechtspraak. Schade en schadeloosstelling', nr. II50.

I28 Bijv. Pol. Hasselt I7 maart I997, DeVerz. I998, 273, noot M. Sommerijns; Pol. Marche-en-Fammene 20 februari 2000, De Verz. 2000, 496; Pol. Dinant I7 juni 2004, VAV 2004, 536.

I29 J. Ronse, L. De Wilde, A. Claeys en I. Mallems, Schade, 7I.

I30 Bijv. 250 euro aan een achterkleinkind voor morele schade wegens het verlies van een overgrootvader (Corr. Aarlen I9 januari 2005, De Verz. 2005, 763); 375 euro aan een metekind van de overledene (Pol. Charleroi 3 december 2003, RGAR 2005, nr. 13966). Vgl. Pol. Namen 23 maart 2007, VAV 2009, 293: 2.000 euro voor morele schade van de meter en voogdes van het overleden kind.

I3I Assisen Brussel 24 september 2008, RGAR 2009, I4.494.

I32 Aan elk van de ouders werd een vergoeding van 30.000 euro toegekend; aan de broer van het slachtoffer 20.000 euro. 
vergoedingen in dit geval niet alleen erkenning beogen te geven aan het leed van de nabestaanden, maar ook aan de collectieve afkeer tegenover de moord.

33. Op het vlak van de omvang van de vergoeding voor morele schade speelt de Indicatieve Tabel een belangrijke rol. Steeds meer verwijzen rechters ter rechtvaardiging van het toegekende bedrag naar de richtbedragen van die tabel. ${ }^{\mathrm{I} 3}$ Anderzijds zijn veel rechters niet te vinden voor een blindelings toepassen van de voorgestelde bedragen en wijken zij ervan af (meestal door de voorgestelde bedragen te verhogen) wanneer de concrete omstandigheden dat rechtvaardigen. ${ }^{\mathrm{I} 34}$ De toekenning van een hoger bedrag wordt vaak verantwoord door te wijzen op de bijzondere tragische omstandigheden van het overlijden ${ }^{135}$ of door het feit dat de naaste het ongeval of het overlijden heeft meegemaakt (bijvoorbeeld ouders die zich naar de plaats van het ongeval haasten en daar hun kind zien liggen en vernemen dat het overleden is). ${ }^{136}$ De (shock)schade als gevolg van de wijze waarop de nabestaande met het overlijden wordt geconfronteerd wordt dus doorgaans niet als een afzonderlijke schade vergoed, maar wordt als een bijzondere omstandigheid mee in rekening gebracht bij de begroting van de morele schade. ${ }^{\mathrm{I} 7}$ Ook het verlies van een enig kind leidt vaak tot de toekenning van een hoger bedrag. ${ }^{138}$

De rechtspraak is minder geneigd om de gebruikelijke bedragen voor morele schade te verminderen door rekening te houden met concrete gegevens. Het komt wel voor dat een geringer bedrag wordt toegekend omdat er geen contact meer was met het slachtoffer. ${ }^{139}$ Ook de hoge leeftijd van het slachtoffer ${ }^{140}$ en de minder bewuste beleving van het overlijden als gevolg van dementie ${ }^{14 \mathrm{I}}$ of als gevolg van de zeer jonge leeftijd van de nabestaande ${ }^{142}$ worden soms ingeroepen om een lagere vergoeding te rechtvaardigen. Wel wordt doorgaans een onderscheid gemaakt naar-

I33 Bijv. Rb. Tongeren 28 maart I996, Limb.Rechtsl. I996, I26; Corr. Antwerpen 5 maart 200I, TAVW 2002, I6I.

I34 Zie de rechtspraak aangehaald bij D. De Callataÿ en N. Estienne, Chronique de jurisprudence. Le dommage, 343 e.v.; A. Van Oevelen, G. Jocqué, C. Persyn en B. De Temmerman, 'Overzicht van rechtspraak. Schade en schadeloosstelling', II05-IIo8.

I35 Bijv. Brussel I5 juni 2004, RGAR 2005, nr. I4.044: een kind van 3,5 jaar verdronk in het zwembad, werd gereanimeerd en nadien in een kunstmatige coma gehouden; Pol. Gent 20 juni 2005, NJW 2005, I277, noot IB; een moeder, reeds weduwe geworden, verloor haar zoon bij een verkeersongeval, enkele maanden nadat haar oudste zoon om het leven was gekomen eveneens bij een verkeersongeval.

I36 Pol. Nijvel 4 april 2000, RGAR 2002, nr. I3.474.

I37 Zie A. Van Oevelen, G. Jocqué, C. Persyn en B. De Temmerman, 'Overzicht van rechtspraak. Schade en schadeloosstelling', I097-I098, nr. 37.I.

I38 Bijv. Bergen I4 maart I997, De Verz. I997, 683, noot M. Lambert; Pol. Namen 23 maart 2007, VAV 2009, 293.

I39 Assisen Brussel 5 november 2008, RGAR 2009, I4.517: aan een zus die reeds verschillende jaren het contact verbroken had met de overleden broer werd een minder hoge vergoeding toegekend dan aan een andere zus en broer die wel nog contact hadden gehouden met het slachtoffer.

I40 Rb. Antwerpen I4 november 2002, De Verz. 2003, 617: aan de kinderen van een 94-jarig slachtoffer wordt een vergoeding toegekend die eenderde bedraagt van het bedrag vooropgesteld door de Indicatieve Tabel.

I4I Pol. Kortrijk I8 december 2000, De Verz. 200I, 833, noot B. Blanpain.

I42 Brussel 4 november I998, RGAR I999, nr. I3I27. 
gelang het slachtoffer al dan niet samenwoonde met zijn nabestaande(n). ${ }^{\mathrm{I} 43}$ De feitelijke scheiding van de partners of het echtpaar leidt vaak tot de afwijzing van de vordering tot vergoeding voor morele schade wanneer geen reële kans op verzoening wordt bewezen. ${ }^{\text {I4 }}$

34. Het overlijden van een dierbare kan ook een depressie bij de nabestaande teweeg brengen. De rechtspraak erkent de materiële en morele schade die daaruit voorvloeit als een afzonderlijke schade, te onderscheiden van de morele schade voorvloeiend uit het overlijden als zodanig (zuivere affectieschade). ${ }^{\mathrm{I} 5}$ Het gaat hierbij meestal om een ouder of een huwelijkspartner die in een depressie verzeilt na het verlies van een kind of echtgenoot. ${ }^{\mathrm{I}{ }^{6}}$ De vergoeding voor schade wegens een depressie na het overlijden van een dierbare heeft dus in de praktijk enkel betrekking op een zeer beperkte kring van naasten.

35. Uit wat vooraf gaat kunnen we besluiten dat, hoewel het Belgische aansprakelijkheidsrecht in beginsel erg inschikkelijk is om aanspraken voor morele schade te erkennen, het probleem van de vergoeding van dergelijke claims beheersbaar blijft omdat de kring van vergoedingsgerechtigden in de praktijk bijna steeds beperkt is tot de gezinsleden en nauwe familieleden van het slachtoffer. Vorderingen tot vergoeding van morele schade van verder verwijderde naasten (zoals vrienden van het slachtoffer) kunnen doorgaans op weinig animo rekenen. Deze laatste vorderingen blijven trouwens een rariteit. Mogelijk speelt schroom ten aanzien van het leed van de nauwe verwanten hierbij een rol.

Het dilemma tussen het toekennen van astronomische bedragen of het toekennen van in het geheel geen vergoeding wordt in België opgelost door het toekennen van schadevergoeding aan de hand van door de rechtspraak gaandeweg ontwikkelde en regelmatig aangepaste forfaitaire bedragen ( $c f$. de Indicatieve Tabel). Zoals Dirix opmerkt, kan een dergelijk stelsel slechts geloofwaardig blijven indien de rechters niet willekeurig afwijken van de voorgestelde bedragen, maar dit enkel doen met een uitdrukkelijke motivering en indien men steeds de zin voor proporties behoudt. ${ }^{147}$ Dit blijkt, door de band genomen, het geval te zijn.

I43 Ook de Indicatieve Tabel bevat verschillende richtbedragen voor samenwonenden en voor nietsamenwonenden. De verklaring hiervoor is dat, hoewel de samenwoning op zich niet bepalend is voor de intensiteit van de affectieve band tussen naasten, het overlijden van een inwonende persoon een grotere weerslag heeft op het dagelijks leven van de nabestaande (D. De Callatä en N. Estienne, Chronique de jurisprudence. Le dommage, 349; A. Van Oevelen, G. Jocqué, C. Persyn en B. De Temmerman, 'Overzicht van rechtspraak. Schade en schadeloosstelling', IIzI-II32, nr. 40.3).

I44 Bijv. Rb. Luik I5 januari 2002, RGAR 2004, nr. I383I; Pol. Gent 3I januari 2005, RW 2005-06, I072. De Indicatieve Tabel stelt deze voorwaarde niet en vermeldt een vergoeding van 3.750 euro voor de feitelijk gescheiden partner.

I45 Zie A. Van Oevelen, G. Jocqué, C. Persyn en B. De Temmerman, 'Overzicht van rechtspraak. Schade en schadeloosstelling', nr. 37.2.

I46 Bijv. Corr. Nijvel 2I oktober I994, RGAR I996, nr. I2.685; Pol. Mechelen 3I januari 2000, AJT 2000-0I, 469.

I47 E. Dirix, 'Abstracte en concrete schade', RW 2000-200I, (I329) I334. 


\subsubsection{Verlies van het voordeel uit het beroepsinkomen van het slachtoffer}

36. Het overlijden van het slachtoffer kan voor zijn nabestaanden economische schade meebrengen ten gevolge van de derving van de beroepsinkomsten. ${ }^{148}$ Het is onbetwist dat nabestaanden die voordeel haalden uit het beroepsinkomen van de overledene aanspraak kunnen maken op vergoeding voor het verlies van dit voordeel. ${ }^{\mathrm{I} 9}$ Hun aanspraak is niet afhankelijk van het bestaan van een recht op onderhoud door de overledene. Naar Belgisch recht volstaat immers de aantasting van een feitelijk (rechtmatig) belang om van schade te kunnen spreken. ${ }^{150}$ Dit is in overeenstemming met de DCFR, die een aanspraak op vergoeding voor 'verlies aan onderhoud' erkent niet enkel ten gunste van personen ten aanzien van wie de overledene een onderhoudsplicht had, maar ook ten gunste van diegenen voor wie de overledene in feite in het levensonderhoud voorzag (bijvoorbeeld een stiefkind bij het overlijden van de stiefvader-kostwinner). ${ }^{151}$

37. Hoewel eenieder die bewijst voordeel te hebben geput uit het inkomen van het overleden slachtoffer naar Belgisch recht gerechtigd is op schadevergoeding, blijft de kring van aanspraakgerechtigden in de praktijk erg beperkt. In onze huidige geïndustrialiseerde en verstedelijkte maatschappij met vooral kerngezinnen en eenoudergezinnen, is het aantal personen dat daadwerkelijk voordeel haalde uit het inkomen van de overledene nu eenmaal doorgaans zeer gering. De meest voor de hand liggende aanspraakgerechtigde is de echtgenoot of (ongehuwd) samenwonende partner. Voor die laatste toont de rechtspraak zich echter strenger: het bewijs van een duurzame relatie wordt vereist (terwijl de stabiliteit van de huwelijksrelatie, ondanks het risico op echtscheiding, wordt vermoed) en de schade wordt vaak op een minder gunstige wijze dan bij gehuwden begroot. ${ }^{152}$ Als de overledene kinderen nalaat, kunnen ook zij aanspraak maken op vergoeding voor hun schade als gevolg van de derving van het beroepsinkomen, voor de periode dat zij nog door

I48 De economische schade van de nabestaanden kan ook bestaan uit het verlies van de huishoudelijke arbeid die aan hun ten goede kwam (A. Van Oevelen, G. Jocqué, C. Persyn en B. De Temmerman, 'Overzicht van rechtspraak. Schade en schadeloosstelling', I057).

I49 O.m. Cass. 29 oktober I974, Arr.Cass. I975, 248; Cass. 4 maart I980, Arr.Cass. I979-80, 826; D. Simoens, Schade en schadeloosstelling, 205-206, nr. I08; T. Vansweevelt en B. Weyts, Buitencontractueel Aansprakelijkheidsrecht, 735 , nr. II5I e.v.

I50 Supra nr. 9. Zo kan een broer, die met zijn zus samenwoonde en mee van haar inkomsten genoot, aanspraak maken op vergoeding voor het verlies aan inkomsten als gevolg van het overlijden van zijn zus, ook al bestond tussen hen geen onderhoudsplicht (Cass. I6 januari 1939, Pas. I939, I, 25). Een kloostergemeenschap heeft recht op vergoeding voor de schade die voortvloeit uit het verlies van het pensioen dat haar overleden kloosterzuster afstond (Cass. 24 maart 1969, Arr. Cass. I969, 690) of uit het verlies van het bestendige voordeel dat de kloostergemeenschap genoot doordat de accidenteel overleden zuster haar activiteiten gratis ten dienste stelde (Gent 26 mei I986, RGAR I988, nr. II367).

I5I VI.- 2:202 (I) (c) DCFR.

I52 Bijv. Corr. Oudenaarde I3 januari 2005, De Verz. 2005, 752; Pol. Gent 30 juni 2006, VAV 2007, I3I. Zie terecht kritisch hierover D. De Callataÿ en N. Estienne, Chronique de jurisprudence. Le dommage, 392-394; E. Dirix, Het begrip schade, I25-I26, nr. I96; A. Van Oevelen, G. Jocqué, C. Persyn en B. De Temmerman, 'Overzicht van rechtspraak. Schade en schadeloosstelling', I057-I059, nr. 29.I. 
de overleden ouder zouden zijn onderhouden. ${ }^{153}$ In steeds minder gevallen wordt aangenomen dat de ouders van het overleden slachtoffer economische schade lijden door het overlijden van hun kind, meestal omdat niet bewezen raakt dat een deel van de inkomsten van het kind aan hen werd besteed. ${ }^{54}$

38. De schade van de aanspraakgerechtigde nabestaanden is in elk geval beperkt tot het deel van het inkomen dat hen persoonlijk ten goede kwam. Om dit te berekenen, moet op het inkomen dat door het overlijden is weggevallen een aftrek worden toegepast die het aandeel uitdrukt van de kost van het persoonlijk onderhoud van het slachtoffer ten aanzien van het gezinsinkomen. ${ }^{155}$

Bij de berekening van de inkomstenschade die de weduwe lijdt ten gevolge van het overlijden van haar echtgenoot, moet de rechter, volgens vaste cassatierechtspraak, abstractie maken van de omstandigheid dat de weduwe tussen het overlijden en het tijdstip van de rechterlijke uitspraak is hertrouwd en deelt in het inkomen van haar nieuwe echtgenoot. ${ }^{156}$ In de lagere rechtspraak wordt soms gerebelleerd tegen dit standpunt. ${ }^{157}$

39. Wanneer het slachtoffer echtgenoot en kinderen in het gezin nalaat, rijst de vraag wie nu precies daardoor economische schade lijdt: de overblijvende echtgenoot en de kinderen, elk voor het deel van het inkomen dat de overledene aan hun onderhoud besteedde, of enkel de echtgenoot die na het overlijden alleen instaat voor de opvoeding en het onderhoud van de kinderen? In een arrest van 6 mei 2002 heeft het Hof van Cassatie aanvaard dat de kinderen zelf economische schade kunnen lijden door het derven van de inkomsten die hun overleden ouder aan hun persoonlijk onderhoud en opvoeding besteedde. ${ }^{158}$ Op grond van dit arrest kon worden aangenomen dat de kinderen persoonlijk gerechtigd zijn op een afzonderlijke vergoeding voor de door hen geleden schade. In een arrest van 23 maart 2005 heeft het Hof echter beslist dat de noodzaak voor de overleden partner om voortaan alleen de financiële last van het onderhoud en de opvoeding van de kinderen te dragen, een eigen schade kan uitmaken. De eigen schade van de overblijvende echtgenoot kan dan ook het gedeelte van de inkomsten van de overledene omvatten dat hij zou hebben besteed aan het onderhoud en de opvoeding van de minderjarige kinderen. ${ }^{159}$ Het is niet duidelijk of het Hof hiermee bedoelt dat de schade van de kinderen verplaatst

I53 D. De Callataÿ en N. Estienne, Chronique de jurisprudence. Le dommage, 389-392; D. Simoens, Schade en schadeloosstelling, 2I2, nr. II2.

I54 Bijv. Antwerpen ro februari 1998, TAVW ı999, 50. Zie D. De Callataÿ en N. Estienne, Chronique de jurisprudence. Le dommage, 387-388; A. Van Oevelen, G. Jocqué, C. Persyn en B. De Temmerman, 'Overzicht van rechtspraak. Schade en schadeloosstelling', I070-I07I, nr. 29.3.

I55 Zie T. Vansweevelt en B. Weyts, Buitencontractueel Aansprakelijkheidsrecht, 737-738, nr. II55-II56. Omdat dit aandeel niet steeds exact kan worden berekend, stelt de Indicatieve Tabel 2008 hiervoor een formule voor (NJW 2008, 717).

I56 O.m. Cass. 29 september I948, Pas. I948, I, 509; Cass. 20 maart I980, Arr.Cass. I979-80, 909; Cass. 29 september I987, TGR I987, I04.

I57 Bijv. Rb. Brugge 4 oktober I995, De Verz. I997, I42.

I58 Cass. 6 mei 2002, RGAR 2004, nr. I3.840 en Soc. Kron. 2002, 519. In dezelfde zin: Pol. Brugge II oktober 2005, RW 2007-08, 244.

I59 Cass. 23 maart 2005, Pas. 2005, 699, TBBR 2006, 445 en RGAR 2007, nr. I4.207. 
is naar de overblijvende ouder zodat alleen die laatste gerechtigd is op vergoeding. Sommige auteurs vinden het, zeker voor de toekomstige schade, onwenselijk dat de overblijvende ouder alleen aanspraak zou kunnen maken op vergoeding. Dit zou de kinderen immers blootstellen aan het risico dat zij, bijvoorbeeld door insolvabiliteit van de overblijvende ouder of verkwisting, verstoken zouden blijven van het deel van de vergoeding dat overeenstemt met het aandeel van de overleden ouder in hun onderhoud en opvoeding en dat hun ten goede zou moeten komen. ${ }^{160}$ Toch is er vanuit een praktisch oogpunt reden om de vergoeding voor het verlies van het inkomen dat de overledene aan zijn gezin besteedde alleen toe te kennen aan de overblijvende ouder. Krachtens artikel 379, tweede lid, BW moet iedere rechterlijke beslissing waarbij uitspraak wordt gedaan over geldsommen die toekomen aan een minderjarige, ambtshalve bevelen dat die geldsommen geplaatst worden op een rekening op naam van de minderjarige. Die rekening is onbeschikbaar tot het tijdstip van de meerderjarigheid. Wanneer dus aan de kinderen persoonlijk een afzonderlijke vergoeding wordt toegekend, blijft die som onbeschikbaar tot aan hun meerderjarigheid, terwijl de overblijvende ouder ondertussen uiteraard wel de opvoeding en het onderhoud van de kinderen moet bekostigen.

\subsubsection{Schade door gemaakte kosten}

40. Begrafeniskosten worden beschouwd als vergoedbare schade van degene die ze heeft betaald, ongeacht of deze persoon erfgenaam is of niet. ${ }^{16 \mathrm{I}} \mathrm{Zij}$ omvatten niet alleen de uitgaven voor de eigenlijke begrafenisplechtigheid, maar ook voor rouwmaaltijd, bloemen, rouwdrukwerk, grafconcessie en grafsteen en dergelijke. ${ }^{162}$ Voor de beoordeling van de aanvaardbaarheid van het uitgegeven bedrag wordt nog vaak verwezen naar de maatschappelijke status van de overledene en de nabestaanden en naar hun financiële mogelijkheden. Vooral de uitgaven voor grafconcessie en de grafsteen worden op grond van dat criterium betwist. ${ }^{16_{3}}$ Bij overlijden van een ouder persoon wordt enkel de vervroegde betaling van het bedrag dat de nabestaande normaal gezien op een later moment had moeten betalen vergoed. ${ }^{164}$

Ook de DCFR beschouwt de begrafeniskosten als 'juridisch relevante schade' van de persoon die de kosten gedaan heeft. ${ }^{165}$ Wat het bedrag betreft, is alleen bepaald dat de gedane uitgaven redelijk moeten zijn; een uitdrukkelijke verwijzing naar de levensstandaard van de overledene leek ongepast. ${ }^{166}$

I6o A. Van Oevelen, G. Jocqué, C. Persyn en B. De Temmerman, 'Overzicht van rechtspraak. Schade en schadeloosstelling', Io65-Io66, nr. 29.2; T. Vansweevelt en B. Weyts, Buitencontractueel Aansprakelijkheidsrecht, 739, nr. II57.I.

I6I Cass. 7 mei 2002, Pas. 2002, IIo6.

I62 D. Simoens, Schade en schadeloosstelling, 250-25I, nr. I32.

I63 A. Van Oevelen, G. Jocqué, C. Persyn en B. De Temmerman, 'Overzicht van rechtspraak. Schade en schadeloosstelling', I05I.

I64 D. Simoens, Schade en schadeloosstelling, 25I-252, nr. I32.

I65 VI.-2:202 (2) (b): 'Where a person has been fatally injured, reasonable funeral expenses are legally relevant to the person incurring them'.

I66 Principles DCFR, Vol. 4, 3228. 
4I. In het verleden werd aan de ouders bij het overlijden van hun kind ook soms een vergoeding toegekend voor de kosten besteed aan de opvoeding en het onderwijs van het kind en die door het overlijden nutteloos zouden zijn geworden. ${ }^{167}$ Die opvatting is ondertussen al enige tijd verlaten. ${ }^{168}$ Een kind is geen investeringsgoed.

\subsubsection{Schade door hulp aan nabestaanden van het slachtoffer}

42. Het komt voor dat nabestaanden na het overlijden van het slachtoffer de zorg op zich nemen van gezinsleden van de overledene. Het reeds vermelde cassatiearrest van 6 november $200 \mathrm{I}^{169}$ betrof een dergelijke situatie: nadat hun dochter was omgekomen bij een ongeval, hadden grootouders hun kleinkind bij zich opgenomen en vorderden zij vergoeding voor de meerinspanningen bij de opvoeding en het onderhoud van het kind. Het Hof heeft erkend dat de vrijwillig verleende prestaties een vergoedbare schade kunnen uitmaken van degene die de prestaties verricht. Wel moet aan bepaalde voorwaarden voldaan zijn om van vergoedbare schade te kunnen spreken. Ten eerste moet voor het vrijwillige optreden een redelijke grond bestaan. Nauwe familiebanden kunnen een dergelijke grond uitmaken. Ten tweede moet de prestatie de schadelijke gevolgen van de fout bij het rechtstreekse slachtoffer lenigen. Het mag ten derde niet de bedoeling zijn geweest van de hulpverlener om de prestaties definitief voor zijn rekening te nemen. Deze voorwaarden zetten een rem op overdreven aanspraken: niet elke vrijwillig geleverde prestatie die tot bijkomende inspanningen noopt, leidt achteraf tot een recht op vergoeding. ${ }^{170}$

Inmiddels hebben feitenrechters de leer van dit arrest toegepast in analoge gevallen. ${ }^{171}$ Zo kende het hof van beroep te Antwerpen schadevergoeding toe aan de grootouders die in het huis van hun vermoorde dochter waren ingetrokken om voor hun minderjarige kleinkinderen (die geen contact meer hadden met hun vader) te zorgen. ${ }^{172}$ Het hof van beroep erkende dat de grootouders een vergoedbare economische schade leden, door de arbeid die zij als gevolg van de onrechtmatige daad verrichtten in het huishouden van hun kleinkinderen en die de kosten van de hulp van derden heeft vervangen. Bovendien konden zij aanspraak maken op een vergoeding voor de morele schade wegens het feit dat ze niet konden genieten van een rustige oude dag en van de vrije tijd waarover ze normaal als gepensioneerden hadden kunnen beschikken.

I67 Gent I6 mei 1923, Pas. I923, II, I96; Brussel I3 juli I934, RGAR I935, nr. I755.

I68 Zie R.O. Dalcq, Traité, II, nr. 3690; E. Dirix, Het begrip schade, I29, nr. 202.

I69 Cass. 6 november 200I, Arr.Cass. 200I, I856, concl. J. Du Jardin, RW 200I-02, I466, concl. J. Du Jardin. Zie ook supra nr. 25.

I70 D. Simoens, 'Materiële en morele schade geleden door grootouders die de zorg op zich namen over hun kleinkinderen, na het overlijden van hun moeder' (noot onder Antwerpen 7 maart 2007), TBBR 2008, 224.

I7I Pol. Brugge 27 oktober 2004, De Verz. 2005, 392, noot P. Graulus en RABG 2005, II46, noot S. Vereecken: aan de grootmoeder die na het overlijden van haar dochter haar kleinzoon onder haar hoede nam, werd een schadevergoeding toegekend voor de meerinspanningen en de meeruitgaven voor diens opvoeding en onderhoud.

I72 Antwerpen 7 maart 2007, TBBR 2008, 222, noot D. Simoens. 
43. Er is op gewezen dat deze benadering problemen doet rijzen, onder meer met betrekking tot de vergoeding van toekomstige schade. ${ }^{173}$ Wanneer aan de hulpverlenende naaste een vergoeding wordt toegekend, niet alleen voor de reeds verrichte prestaties, maar ook voor de toekomstige schade wegens het verlenen van hulp, ${ }^{174}$ kan een penibele situatie ontstaan wanneer op een bepaald ogenblik de naaste, om welke reden ook (onenigheid tussen de geholpene en zijn naaste, overlijden van deze laatste) zijn prestaties niet meer zou verlenen. De hulpverlener zou dan (gedeeltelijk) vergoed zijn voor prestaties die hij nooit zal leveren, terwijl het slachtoffer niet vergoed zou zijn voor de (bezoldigde) hulp van derden waarop het een beroep moet doen na de stopzetting van de vrijwillige hulp. Dit gevaar kan worden vermeden door te aanvaarden dat de schade van het slachtoffer (of van de hulpbehoevende nabestaande) alleen overgaat naar de helpende naaste in zoverre de hulp daadwerkelijk wordt verleend. De rechter zou kunnen oordelen - maar dit behoort uiteraard tot zijn soevereine appreciatie - dat de toekomstige vrijwillige hulp niet voldoet aan de vereiste zekerheid van de schade. De naaste zou dan alleen aanspraak kunnen maken op vergoeding voor de reeds geleverde prestaties; voor de schade wegens hulp van derden in de toekomst zou het slachtoffer (of de hulpbehoevende nabestaande) zelf gerechtigd blijven op vergoeding.

\subsection{De invloed van de eigen schuld van het slachtoffer op het recht op vergoeding van zijn naasten en nabestaanden}

44. Wanneer het rechtstreekse slachtoffer zelf een fout heeft begaan in oorzakelijk verband met de schade, wordt de schadelast in de regel verdeeld tussen dat slachtoffer en de aansprakelijke derde. Na overlijden van het slachtoffer kunnen zijn nabestaanden de vordering, die een actief bestanddeel van de nalatenschap uitmaakt, verder uitoefenen. In dat geval moet de aansprakelijke derde de schade ook slechts gedeeltelijk vergoeden. Dit is logisch: de erfgenamen vorderen immers schadevergoeding voor de schade die hun rechtsvoorganger leed. De tegenwerpelijkheid van de fout van het oorspronkelijke slachtoffer aan de nabestaanden die ex haerede optreden, wordt dan ook algemeen aanvaard in het Belgische recht. ${ }^{175}$

I73 I. Boone, 'Schadevergoeding voor vrijwillige prestaties', NJW 2006, (740) 745-746; B. De Temmerman, 'Recente cassatierechtspraak inzake schade en schadeloosstelling (200I-2006), RGAR 2003 , nr. 13.763 , 5. De regel van het grootouderarrest kan ook voor problemen zorgen op het vlak van de subrogatoire verhaalsrechten in het socialezekerheidsrecht, in het bijzonder het verhaalsrecht van de arbeidsongevallenverzekeraar. Dit laten wij hier echter buiten beschouwing (zie daarover de in deze noot geciteerde bijdragen).

I74 Dat was het geval in de zaak die aanleiding gaf tot het cassatiearrest van 6 november 200I, maar omdat de toekenning van de vergoeding voor toekomstige schade niet was aangevochten, kon het Hof daarover geen uitspraak doen. Ook het hof van beroep te Antwerpen kende een vergoeding toe aan de grootouders niet alleen voor de schade wegens reeds verrichte arbeid, maar ook voor de arbeid die zij zouden verrichten in de toekomst tot op dag waarop hun kleindochter 22 jaar wordt (Antwerpen 7 maart 2007, TBBR 2008, 222, noot D. Simoens).

I75 B. Weyts, 'Familiebanden, aansprakelijkheid en verzekeringen', RW 2004-05, 8I-82. 
Volgens vaste cassatierechtspraak sinds $1962^{176}$ is de fout van het slachtoffer ook tegenwerpelijk aan de naasten of nabestaanden wanneer zij een vordering instellen tot vergoeding van de schade die zij persoonlijk lijden door de letsels of het overlijden van het rechtstreekse slachtoffer. ${ }^{177}$ In een arrest van 28 juni 2006 formuleert het Hof de regel als volgt. ${ }^{178}$

'Het recht op vergoeding van de gevolgschade die de naasten van de getroffene lijden, ook als die persoonlijk door hen geleden wordt, vindt zijn ontstaan uitsluitend in de familiale en affectieve banden die hen met de overleden getroffene verenigden. Wanneer de schade werd veroorzaakt door de samenlopende fouten van een derde en van de getroffene, mag die derde niet veroordeeld worden tot de volledige vergoeding van de gevolgschade die de naasten van de getroffene lijden.'

De naasten en nabestaanden kunnen dus voor hun schade bij weerkaatsing slechts vergoed worden in de mate waarin het rechtstreekse slachtoffer vergoeding had kunnen verkrijgen. ${ }^{179}$ Deze regel wijkt af van het autonoom karakter van weerslagschade en verbindt verschillende rechtsgevolgen aan de rechtstreeks inslaande en gereflecteerde schade: ${ }^{180}$ degenen die zich op deze laatste beroepen, hebben geen recht op een integrale schadeloosstelling, ook al hebben zij zelf geen fout begaan.

45. In de doctrine was - en is nog steeds - veel kritiek te horen op deze rechtspraak. Sommige auteurs treden de oplossing wel bij, maar bekritiseren de redenen waarop het Hof die steunt. ${ }^{181}$ Anderen richten hun pijlen zowel op de redenering als op de oplossing zelf. ${ }^{182}$ De kritiek luidt onder meer dat de door het Hof aanvaarde regel in

I76 In I96I nam het Hof van Cassatie nog aan dat de naasten recht hebben op integrale vergoeding van de aansprakelijke derde, ook wanneer het rechtstreekse slachtoffer door zijn fout heeft bijgedragen tot de schade (Cass. I5 mei I96r, 2 arresten, RCJB I962, I65, noot J. Dabin). Men neemt aan de kritische noot van Dabin bij de arresten van I96r het Hof ertoe gebracht heeft zijn standpunt te veranderen.

I77 Cass. I9 december I962, RW 1962-63, I235; Cass. I februari 1994, Arr.Cass. I994, I29; Cass. 2 maart 1995, Arr.Cass. 1995, 255, De Verz. I995, 572, JLMB I996, 339, noot A. PIRARD, RGAR I997, nr. I2.872 en RRD I996, 605, noot J. FAGNART; Cass. 5 oktober 1995, Arr.Cass. 1995, 844; Cass. 25 februari 2004, RGAR 2005, nr. I40I3 en Pas. 2004, 327; Cass. 28 juni 2006, Pas. 2006, I534.

I78 Cass. 28 juni 2006, Pas. 2006, I543.

179 Zie hierover o.m. L. Cornelis, 'Genadeloos met genegenheid: recht of on(te)recht?', in De indicatieve tabel herzien, Brugge, die Keure, 2008, (97) I09-I29; J.-L. Fagnart, La causalité, Kluwer, 2008, 279-282; D. Simoens, Schade en schadeloosstelling, II3-II6, nr. 62; M. Van Quickenborne, Oorzakelijk verband tussen onrechtmatige daad en schade, Mechelen, Kluwer, 2007, 96-97; B. Weyts, De fout van het slachtoffer in het buitencontractueel aansprakelijkheidsrecht, Antwerpen, Intersentia, 2003, 238, nr. 27I en 305-309, nrs. 350-356.

I80 D. Simoens, Schade en schadeloosstelling, II5.

I8I R.O. Dalcq, 'De l'opposabilité de la faute de la victime à ses ayants cause à titre universel', RGAR I963, nr. 7092; D. Simoens, Schade en schadeloosstelling, II6. Deze laatste auteur kan niettemin, uit billijkheidsoverwegingen vanuit het standpunt van de schadeverwekker, begrip opbrengen voor de cassatierechtspraak.

I82 J.-L. Fagnart, La causalité, 279-282; L. Cornelis, 'L'apparence trompeuse',72; L. Cornelis, 'Genadeloos met genegenheid: recht of on(te)recht?', in De indicatieve tabel herzien, Brugge, die Keure, 2008, (97) I09-I29; B. Weyts, De fout van het slachtoffer in het buitencontractueel aansprakelijkheidsrecht, nrs. $354-356$. 
strijd is met de equivalentieleer, aangezien zij neerkomt op een partiële verbreking van het causaal verband door de familie- en genegenheidsband. ${ }^{183}$ De tegenwerpelijkheid van de fout van het slachtoffer aan de nabestaanden is bovendien strijdig met de idee dat de familiale solidariteit de toepassing van de aansprakelijkheidsregels niet beïnvloedt. ${ }^{184}$

Het is juist dat de doorwerking van de fout van het rechtstreekse slachtoffer op de vordering van naasten en nabestaanden voor hun weerslagschade zich niet gemakkelijk juridisch laat inpassen in ons aansprakelijkheidsrecht. Ook op de redenen die het Hof aanhaalt om de regel te verantwoorden, valt wat te zeggen: dat de naasten schade lijden is weliswaar te verklaren door hun persoonlijke affectieband met het slachtoffer, maar het recht op vergoeding vindt zijn grondslag niet in die band, maar in de wet. ${ }^{185}$ De dogmatische kritiek dat deze rechtspraak afbreuk doet aan artikel I382 BW en aan de equivalentieleer helpt ons echter inhoudelijk niet veel vooruit. In het Belgische aansprakelijkheidsrecht is elke inperking van het recht op schadevergoeding voor een (rechtmatig en zeker) nadeel dat het gevolg is van andermans fout, strikt genomen een afwijking van artikel ${ }_{3} 382 \mathrm{BW}$. Maar dit neemt niet weg dat sommige inperkingen wel wenselijk en gerechtvaardigd kunnen zijn. Wat de hier besproken problematiek betreft, kan men vaststellen dat de DCFR, zoals de meeste Europese rechtsstelsels, erkent dat de gedeelde aansprakelijkheid wegens de eigen fout van het slachtoffer tegenwerpelijk is aan derden die schade lijden als gevolg van de letsels of het overlijden van het slachtoffer. ${ }^{186}$ Volgens de toelichting beantwoordt deze regel aan een rechtvaardigheidsoverweging die in brede kringen aanvaard wordt in Europa.$^{187}$ Het aanhoudende verzet van een deel van de Belgische doctrine tegen deze regel lijkt dan ook, vanuit rechtsvergelijkend oogpunt, een 'achterhoedegevecht' te zijn. De problematiek heeft trouwens veel van zijn praktische betekenis verloren sinds de invoering van het bijzonder vergoedingsregime voor zogenoemd zwakke weggebruikers (artikel 29bis WAM-wet). De (niet-opzettelijke) fout van het slachtoffer heeft geen invloed op het recht op vergoeding krachtens dit regime. ${ }^{\text {i88 }}$

I83 L. Cornelis, 'Genadeloos met genegenheid: recht of on(te)recht?', in De indicatieve tabel herzien, (97) II7. Zie ook B. Weyts, De fout van het slachtoffer in het buitencontractueel aansprakelijkheidsrecht, nr. 355 .

I84 B. Weyts, De fout van het slachtoffer in het buitencontractueel aansprakelijkheidsrecht, nr. 356.

I85 J.-L. Fagnart, La causalité, 28I, nr. 554; B. Weyts, De fout van het slachtoffer in het buitencontractueel aansprakelijkheidsrecht, nr. 354 .

I86 VI. - 5:50I: Extension of defences against the injured person to third parties.

I87 Principles DCFR, Vol. 4, 37 I8.

I88 De opzettelijke fout is wel relevant. Het zesde lid van art. 29bis, par. I WAM-wet bepaalt immers dat slachtoffers die ouder zijn dan I4 jaar en het ongeval en zijn gevolgen gewild hebben, zich niet kunnen beroepen op de bepalingen van dit artikel. In een arrest van 26 juni 2008 (NJW 2009, 275, noot IB en RGAR 20I0, nr. I4.602) heeft het Hof van Cassatie aanvaard dat de uitsluiting wegens een opzettelijke fout van het slachtoffer tegenwerpelijk is aan de nabestaanden van dat slachtoffer. Volgens het Hof wil artikel 29bis WAM-wet de rechten van de rechthebbenden afstemmen op de rechten van het slachtoffer. Daaruit volgt dat, wanneer het slachtoffer krachtens het zesde lid van art. 2gbis, par. I WAM-wet geen recht heeft op vergoeding, zijn rechthebbenden evenmin aanspraak kunnen maken op vergoeding van de schade die zij lijden door het letsel of het overlijden van het slachtoffer. 


\section{$4 \quad$ Schade van derden die naar aanleiding van de schade van het slachtoffer tot uitkeringen of prestaties verplicht zijn}

\section{I Inleiding}

46. Niet zelden geeft de schade van het slachtoffer er aanleiding toe dat bepaalde personen, andere dan de aansprakelijke, uitkeringen of prestaties moeten doen waartoe zij wettelijk of contractueel verplicht zijn. Hierbij valt in de eerste plaats te denken aan schuldenaars van het slachtoffer die de schade geheel of gedeeltelijk moeten vergoeden. In de tweede plaats kan gedacht worden aan publieke hulp- en veiligheidsdiensten (in het bijzonder brandweer en civiele bescherming) die ingevolge het schadegeval moeten optreden in het algemeen belang of als dienstverlener.

\subsection{Schuldenaars van het slachtoffer}

47. Bij letselschade en ook - zij het in mindere mate - bij zaakschade van de benadeelde, zijn vaak een of verschillende personen ertoe gehouden uitkeringen te doen aan de benadeelde. Het gaat om 'derde-betalers', zoals de werkgever die gedurende een bepaalde periode het loon moet blijven betalen aan een tijdelijk arbeidsongeschikt personeelslid, of de verzekeraar die een deel van de hospitalisatiekosten voor zijn rekening neemt of de schade aan de auto vergoedt. Daarnaast kan op het terrein van zaakschade gedacht worden aan de gevallen waarin een schuldenaar krachtens een overeenkomst met de eigenaar voor het behoud van de zaak moet instaan en deze zaak beschadigd of ontvreemd wordt door de fout van een derde. Kunnen deze schuldenaars aanspraak maken op vergoeding ten laste van de aansprakelijke derde?

48. Derde-betalers, zoals werkgevers, eigenschadeverzekeraars en socialezekerheidsinstellingen, beschikken meestal over een specifiek wettelijk verhaalsrecht tegen de aansprakelijke (doorgaans gebaseerd op subrogatie in de rechten van het slachtoffer). ${ }^{189}$ De vraag blijft echter of zij, los van dit specifieke verhaalsrecht, de aansprakelijke ook rechtstreeks op grond van artikel I382 e.v. BW kunnen aanspreken tot vergoeding van hun uitgaven. ${ }^{190}$ In het verleden vormde de leer van de doorbraak van het oorzakelijk verband een struikelblok: het oorzakelijk verband tussen de fout van de dader en de uitgaven van de werkgever zou zijn doorbroken door de wettelijke, contractuele of reglementaire verplichting op grond waarvan die uitgaven werden verricht. ${ }^{19 \mathrm{I}} \mathrm{Op}$ aansturen van de doctrine heeft het Hof van Cassatie in 200 r deze leer verlaten. De vraag of voor deze uitgaven vergoeding kan worden

I89 Zie bijv. art. 4I Wet Landverzekeringsovereenkomst; art. 47 Arbeidsongevallenwet; art. I36 par. 2, vierde lid, Ziektewet.

I9o De tekst in dit randnummer en in het volgende randnummer is gebaseerd op H. Bocken en I. Boone, Aansprakelijkheidsrecht en andere schadevergoedingsmechanismen, nr. 79-80. Zie uitgebreid over deze problematiek I. Boone, Verhaal van derde-betalers, 425-474 en de verwijzingen aldaar.

I9I Cass. II april 1938, Arr.Cass. I938, 85; Cass. I7 maart I969, Arr.Cass. I969, 669; Cass. 5 december I978, Arr.Cass. I978-79, 399; Cass. 25 september I996, RGAR I998, nr. I2.9I7. 
toegekend, wordt nu benaderd vanuit het schadebegrip. Het Hof stelt namelijk dat de gedane uitgaven een vergoedbare schade kunnen uitmaken, behoudens wanneer zij, blijkens de inhoud of de strekking van de overeenkomst, de wet of het reglement, definitief voor rekening moeten blijven van degene die ze gedaan heeft. ${ }^{192}$ Toepassing makend van dit criterium, aanvaardt het Hof van Cassatie thans dat de loonuitgaven die een (overheids)werkgever heeft gedaan ten gunste van een tijdelijk arbeidsongeschikt personeelslid een eigen schade van de werkgever zijn, aangezien uit de toepasselijke voorschriften - die in een subrogatoir verhaal voorzien - niet blijkt dat deze uitgaven definitief voor zijn rekening moeten blijven. ${ }^{193}$, , ${ }^{194}$ Het belang van deze rechtspraak voor overheidswerkgevers is niet gering. ${ }^{195}$ Doordat zij het doorbetaalde brutoloon als hun eigen schade kunnen terugvorderen, ontsnappen zij aan de beperking (tot een vergoeding berekend op nettobasis) die een subrogatoir verhaal oplevert. Het Hof van Cassatie aanvaardt niettemin een beperking op de vergoedingsplicht van de aansprakelijke derde, namelijk in het geval waarin de arbeidsongeschiktheid mee te wijten is aan de schuld van het getroffen personeelslid zelf. In dat geval kan de tewerkstellende overheid slechts aanspraak maken op vergoeding van de schade die hij daardoor lijdt tot beloop van het aandeel van de derde in de schade. De arbeidsongeschiktheid die te wijten is aan de schuld van het getroffen personeelslid zelf is volgens het Hof een risico dat de werkgever definitief

192 Cass. In februari 200I, AR C.99.00I4.N, Arr.Cass. 200I, 324, De Verz. 200I, 777, noot P. Graulus, Pas. 200I, 322, RW 200I-02, 238 en TBBR 2003, I82, noot S. Heremans; Cass. I9 februari 200I, AR C.99.0228.N, Arr.Cass. 200I, 330, De Verz. 200I, 777, noot P. Graulus en Pas. 200I, 329; Cass. Ig februari 200I, AR C.00.0242.N, Arr.Cass. 200I, 318, De Verz. 2001, 780, noot P. Graulus, Pas. 200I, 332 en Verkeersrecht 200I, 22I; Cass. I9 februari 200I, AR C.99.0I83.N, Arr.Cass. 200I, 329, De Verz. 2001, 769, noot P. Graulus en Pas. 2001, 327; Cass. 20 februari 200I, Arr.Cass. 2001, 336 en Pas. 200I, 334; Cass. Io december 200I, Arr.Cass. 200I, 2117, Pas. 2001, 2046, RW 2003-04, 583 , noot en TBBR 2003, 523, noot T. Robert; Cass. 4 maart 2002, JLMB 2004, noot J. Wildemeersch; Cass. Io april 2003, JLMB 2004, 243, noot J. Jeunehomme en J. Wildemeersch, Pas. 2003, 800, RW 2005-06, I259, noot en RABG 2005, I08I, noot I. Boone; Cass. 3 december 2003, Pas. 2003, I934; Cass. 23 februari 2004, JTT 2004, afl. 900, 472; Cass. 9 januari 2006, NJW 2007, 22I, noot IB en De Verz. 2007, 97; Cass. I6 januari 2006, RGAR 2006, I4.I98, noot; Cass. I8 september 2007, NJW 2007, 748, noot IB en RW 2007-08, 987, concl. M. De Swaef; Cass. I oktober 2007, Pas. 2007, I67I; Cass. 27 november 2007, NJW 2008, 594, noot IB; Cass. II september 2009, AR C.08.0277.F; Cass. 2I september 2009, NJW 2009, 902, noot IB.

I93 Cass. I9 februari 200I, AR C.99.00I4.N, Arr.Cass. 200I, 324, De Verz. 200I, 777, noot P. Graulus, Pas. 200I, 322, RW 200I-02, 238 en TBBR 2003, I82, noot S. Heremans; Cass. Io december 200I, Arr.Cass. 2001, 2117, Pas. 200I, 2046, RW 2003-04, 583, noot en TBBR 2003, 523, noot T. Robert; Cass. 3 december 2003, Pas. 2003, I934; Cass. 2I september 2009, NJW 2009, 902, noot IB.

I94 Pogingen van overheidswerkgevers om andere uitkeringen dan loonbetalingen te laten beschouwen als vergoedbare schade mislukten daarentegen. Wanneer de publiekrechtelijke werkgever een arbeidsongevallenrente moet betalen aan een personeelslid dat blijvend arbeidsongeschikt is, dan kan hij die niet als een eigen schade verhalen op de aansprakelijke derde (Cass. 9 januari 2006, NJW 2007, 22I, noot IB; Cass. I2 november 2008, JLMB 2009, 258, noot N. Simar, TBBR 2009, 5I9, noot J. Decharneux, T.Pol. 2009, 23 en VAV 2009, 193; Cass. 30 juni 2009, VAV 2009, 429). Hetzelfde geldt voor het invaliditeitspensioen dat een overheidswerkgever moet betalen wegens de vervroegde oppensioenstelling van een werknemer die een bestendige arbeidsongeschiktheid heeft opgelopen als gevolg van de fout van een derde (Cass. 26 mei 2009, NJW 2009, 590, noot IB en RW 2009-Io, 622, concl. M. De Swaef).

I95 De regel van deze arresten kan ook toegepast worden op werkgevers uit de privésector. Voor hen is dit echter van weinig belang omdat zij krachtens de Arbeidsovereenkomstenwet (art. 52, par. 4, 54, par. 4 en 75) over een eigen (niet-subrogatoir) recht tegen de aansprakelijke beschikken tot terugvordering van het gewaarborgd loon en de daarop verschuldigde bijdragen. 
moet dragen. ${ }^{196}$ Men kan hierin een toepassing zien van de identificatietheorie, op grond waarvan fouten van ondergeschikten aan de (benadeelde) werkgever worden toegerekend omdat ze in zijn risicosfeer liggen, zodat hij van de medeaansprakelijke derde slechts een gedeeltelijke vergoeding kan vorderen. ${ }^{\mathrm{I}}{ }^{97}$

49. De vraag rees dan of andere derde-betalers die de slachtoffers geheel of gedeeltelijk vergoeden bij een schadegeval, zoals schadeverzekeraars, ziekenfondsen en arbeidsongevallenverzekeraars, eveneens een beroep kunnen doen op artikel I382 BW om hun uitgaven als een eigen schade op de aansprakelijke te verhalen. Het Hof blijkt niet zover te willen gaan. Schadeverzekeraars ${ }^{198}$ die vergoeding uitkeren naar aanleiding van andermans fout, kunnen niet als benadeelden in de zin van arti-

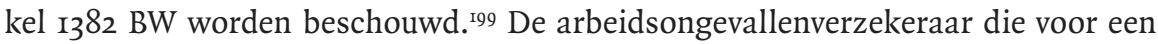
werkgever uit de publieke sector het arbeidsongevallenrisico dekt, lijdt zelf geen schade voortvloeiend uit de letsels of het overlijden van het slachtoffer. ${ }^{200}$ Ook het ziekenfonds dat aan het slachtoffer van een onrechtmatige daad prestaties verstrekt, lijdt geen schade als gevolg van die onrechtmatige daad. ${ }^{201}$ De overheidswerkgevers zijn dus de enige categorie derdebetalers wier positie de facto verbeterd wordt, en dan nog enkel voor wat betreft de betaling van het loon.

50. Welke de dogmatische en de beleidsmatige overwegingen zijn op grond waarvan de ene derdebetaler wel als schadelijder wordt aangemerkt en de andere niet, is niet duidelijk op te maken uit de rechtspraak van het Hof van Cassatie. Of de derde-betaler de schadelast definitief moet dragen op grond van de inhoud of de strekking van de betrokken wet of overeenkomst is onvoldoende om de verschillen in behandeling te verklaren. Ook (onder meer) de schadeverzekeraar en de arbeidsongevallenverzekeraar beschikken over een wettelijk subrogatierecht tegen de aansprakelijke derde, waaruit zou kunnen worden afgeleid dat zij blijkens de inhoud en de strekking van de wet de gedane uitgaven niet definitief moeten dragen. Toch worden de door hen gedane uitkeringen niet als een vergoedbare schade beschouwd. Een achterliggende verklaring kan zijn dat de betaling van de verzekeringsvergoeding wanneer het gedekte risico zich voordoet, geen verstoring is van de normale uitvoering van de verzekeringsovereenkomst maar precies de essentie daarvan uitmaakt. Het (nochtans persoonlijke en rechtmatige) belang van de verzekeraar om zijn uitgaven als een eigen schade af te wentelen op de aansprakelijke behoort daarom niet tot de belangen die bescherming verdienen langs het aansprakelijkheidsrecht. ${ }^{202}$ Dit stemt overeen met het criterium

I96 Cass. 2I september 2009, NJW 2009, 902, noot IB.

I97 Zie daarover B. Weyts, De fout van het slachtoffer in het buitencontractueel aansprakelijkheidsrecht, 223 e.v., nr. 255 e.v.

I98 Sommenverzekeringen voor een vast bedrag hebben geen wettelijk subrogatoir verhaal tegen de aansprakelijke (art. 49 Wet Landverzekeringsovereenkomst)

I99 Cass 26 maart 2003, De Verz. 2004, 229.

200 Cass. 30 november 2009, AR C.09.0I67.N. Zie ook Cass. 24 april 2002, De Verz. 2002, 95I.

201 Cass. 3 september 2003, Verkeersrecht 2003, 328.

202 I. Boone, Verhaal van derde-betalers, nr. 489. 
voorgesteld door Dirix: contractuele belangen komen alleen voor bescherming in aanmerking wanneer de normale en vrijwillige uitvoering van de overeenkomst op onrechtmatige wijze door de derde wordt doorkruist. Dat is niet het geval voor de verzekeraar die aan een benadeelde-verzekerde bepaalde uitkeringen heeft gedaan naar aanleiding van de fout van een derde, aangezien het schadegeval in de verzekeringsovereenkomst een normale en voorzienbare gebeurtenis oplevert, waarvoor de verzekeraar het risico op zich heeft genomen. ${ }^{203}$

5I. Er is daarentegen wel een vergoedbare schade in de gevallen waarin de schuldenaar krachtens een overeenkomst met de eigenaar voor het behoud van de zaak moet instaan en deze zaak beschadigd of ontvreemd wordt door de fout van een derde. Door de werking van de overeenkomst komt de schade die normaal gezien uitsluitend de eigenaar zou treffen, geheel of gedeeltelijk te liggen bij diegene die voor het behoud van de zaak moet instaan (bijvoorbeeld een huurder, bewaarnemer). Aangenomen wordt dat deze laatste in dat geval schade lijdt waarvoor hij de aansprakelijke derde tot vergoeding kan aanspreken. De beschadiging moet immers als een storende factor ten aanzien van de normale uitvoering van de overeenkomst worden beschouwd. ${ }^{204}$ Dit heeft het Hof van Cassatie recent nog erkend met betrekking tot een bewaarnemer van onrechtmatig ontvreemde sommen. ${ }^{205}$ De federale overheidsdienst Financiën beschikte bij De Post over een zichtrekening. Door misleiding van een bediende van de Post werd een bedrag van ruim 92.00o euro van deze rekening gedebiteerd en gestort ten voordele van een derde. De Post had dit bedrag teruggestort op de rekening van de federale overheidsdienst Financiën en stelde zich burgerlijke partij tegen de derde die zich de sommen bedrieglijk had eigen gemaakt. Deze laatste voerde aan dat alleen de eigenaar van de ontvreemde gelden (in casu de federale overheidsdienst Financiën) als benadeelde van het misdrijf kan worden beschouwd. De Post, die geen eigenaar was van de gelden, maar deze ter uitvoering van haar contractuele verbintenissen aan de rechtmatige eigenaar had terugbetaald, zou geen persoonlijke schade hebben geleden als gevolg van het misdrijf zelf. Het Hof oordeelde dat de enkele omstandigheid dat hij die gelden in bewaring heeft, de bewaargever in uitvoering van een contractuele verbintenis terugbetaalt wanneer een derde zich deze gelden bedrieglijk eigen makkt, niet uitsluit dat de bewaarder daardoor schade lijdt.

52. We kunnen dus besluiten dat de vraag of de schuldenaar van het slachtoffer de aansprakelijke derde kan aanspreken tot vergoeding van de uitkeringen of prestaties waartoe hij als gevolg van het schadegeval gehouden is, zich niet in het algemeen laat beantwoorden. De aard en de strekking van de overeenkomst of de wettelijke regeling op grond waarvan de uitgave of prestatie is verricht, zijn daartoe bepalend. Een opvallende vaststelling hierbij is dat het bestaan van een feitelijk nadeel

203 E. Dirix, Obligatoire verhoudingen tussen contractanten en derden, Antwerpen, Maarten Kluwer, I984, 222-223.

204 E. Dirix, Obligatoire verhoudingen tussen contractanten en derden, 224.

205 Cass. 27 november 2007, NJW 2008, 594, noot IB. 
ingevolge de aantasting van een persoonlijk en rechtmatig belang niet steeds voldoende is om te kunnen spreken van een vergoedbare schade. Aan dat criterium is immers ook voldaan voor de verzekeraar die na het schadegeval een vergoeding uitkeert aan de benadeelde-verzekerde. Toch lijdt hij geen vergoedbare schade, omdat - zoals we hiervoor hebben besproken - zijn belang als niet beschermwaardig wordt beschouwd. Opdat schade vergoedbaar zou zijn, moet zij dus voortvloeien uit de aantasting van een belang dat beschermwaardig wordt bevonden. Aan dit vereiste is niet steeds voldaan bij contractuele of wettelijke schuldenaars. We hebben hier derhalve te maken met een uitzondering op het beginsel dat artikel $1382 \mathrm{BW}$ bescherming biedt aan elk rechtmatig belang. ${ }^{206}$

\subsection{Publieke hulp- en veiligheidsdiensten}

53. Schadegevallen geven dikwijls aanleiding tot interventies van publieke hulp- en veiligheidsdiensten. Dergelijke diensten kunnen bijvoorbeeld ingezet worden om brand te bestrijden, de rijbaan vrij te maken na een ongeval, een persoon in nood te redden of vervuiling te bestrijden. Wanneer de interventie nodig was omwille van een schadegeval waarvoor een derde persoon aansprakelijk is, rijst ook hier de vraag of de gemaakte kosten ten laste kunnen worden gelegd van de aansprakelijke. ${ }^{207}$

54. Zoals bij de hiervoor besproken 'derde-betalers' nam de rechtspraak aanvankelijk aan dat het causaal verband tussen de kosten van de interventies en de onrechtmatige daad van de derde verbroken was door de wettelijke verplichting ter uitvoering waarvan zij werden verricht. ${ }^{208} \mathrm{Naar}$ aanleiding van de vordering van een gemeente die de weg had schoongemaakt nadat een vrachtwagen zijn lading was verloren, zwakte het Hof van Cassatie in 1988 deze leer af door te aanvaarden dat het causaal verband niet wordt verbroken wanneer de wettelijke of reglementaire verplichting 'secundair' is ten opzichte van de herstelplicht van de dader van de onrechtmatige daad. ${ }^{209}$ Dit was het geval voor de gemeente die een weg vrijmaakt. ${ }^{210}$ De verplichting van de gemeente om brand te bestrijden en de kosten daarvan te dragen, was volgens het Hof daarentegen geen secundaire verplichting. ${ }^{21}$

Zoals eerder al werd aangestipt, heeft het Hof in 200 I de leer van de verbreking van het causaal verband helemaal verlaten en benadert het nu de problematiek

206 Zie ook H. Bocken en I. Boone, Aansprakelijkheidsrecht en andere schadevergoedingsmechanismen, 53.

207 Zie A. Pütz, 'Les frais générés par l'intervention des services d'incendie des villes et communes: un préjudice réparable?’ (noot onder Vred. Eupen 20 april 2005), T.Vred. 2008, 277-29I.

208 Cass. 28 april I978, Arr.Cass. I978, roo4, concl. F. Dumon (m.b.t. een vordering van de Stad Antwerpen tot vergoeding van de kosten die zij gedaan had om het wrak van een schip te bergen dat gezonken was na een aanvaring in de haven); Cass. I3 februari I980, RW I98I-82, 24 (m.b.t. een vordering van de Stad Luik wegens bestrijding van een brand).

209 Cass. I3 april I988, Arr.Cass. I987-88, I020, Pas. I988, I, 943, concl. Janssens de Bisthoven en TBBR I988, 436, noot G. Delvoie.

210 Cass. 9 juni i988, Arr.Cass. I987-88, I30I.

2 II Cass. 26 maart I999, Arr.Cass. I999, 444. In dezelfde zin Kh. Antwerpen 30 juni I998, RHA I998, 342; Vred. Eupen 20 april 2005, T.Vred. 2008, 276, noot A. Pütz. Contra Luik 24 maart 1995, Pas. I995, II, 8 (het betrof een interventie n.a.v. een opzettelijke brandstichting). 
vanuit het schadebegrip: de uitgaven kunnen een vergoedbare schade uitmaken, behalve wanneer uit de strekking van de wettelijke of reglementaire verplichting blijkt dat de uitgaven definitief voor rekening moeten blijven van degene die ze moet verrichten. ${ }^{212}$ Zo aanvaardde het Hof dat de last van de herstelling van wegen niet definitief gedragen moet worden door het bestuur wanneer de schade veroorzaakt is door de fout van een derde, ook al heeft dat bestuur personeel in dienst om die herstelling uit te voeren. ${ }^{213}$ In een arrest van II september 2009 bracht het Hof de regel van 200 I nogmaals in herinnering naar aanleiding van een geval waarin ordediensten hadden moeten ingrijpen om een op de afrit van de snelweg gekantelde vrachtwagen te verplaatsen. ${ }^{214}$ Het depanneren van het voertuig werd toevertrouwd aan een sleepdienst, aan wie de Staat de sleepkosten diende te vergoeden. De Belgische Staat vorderde daarop de kosten terug van de BA-verzekeraar van de vrachtwagen. De beslissing van de appelrechter dat de Staat voor de sleepkosten geen vergoeding kon vorderen omdat die kosten geen schade van een derde vormen, werd vernietigd.

Vermelding verdient ook de beslissing van het hof van beroep te Gent dat de kosten van veiligheidsmaatregelen die een gemeente had genomen nadat bij een schadegeval in de context van een wegtransport een gevaarlijke vloeistof uit een tankcontainer was weggevloeid, voor de gemeente een vergoedbare schade vormen die niet definitief voor haar rekening moet blijven. ${ }^{215}$

55. De benadering via het schadebegrip impliceert evenwel niet dat de kosten van elke interventie bij een schadegeval verhaald kunnen worden op de aansprakelijke. Zo wordt verdedigd dat de kosten voor de bestrijding van brand en ontploffing definitief ten laste zouden moeten blijven van de overheid. ${ }^{216}$ Deze dienst wordt gefinancierd door de belastingbetalers en het is redelijk dat zij daarvan 'gratis' kunnen genieten, ook wanneer zij de brand door hun (niet-opzettelijke) fout hebben veroorzaakt. ${ }^{217}$ Voor dit standpunt kan steun worden gevonden in de regeling die de wet van 15 mei 2007 betreffende de civiele veiligheid ${ }^{218}$ heeft uitgewerkt voor het verhaal van de kosten van de opdrachten. Artikel I78, paragraaf I van die wet bepaalt dat de kosten van bepaalde interventies (waaronder een forfaitair bedrag voor het vervoer met de ambulance voor dringende geneeskundige hulpverlening) verhaald moeten worden op de begunstigde. Voor interventies die onder de algemene wettelijke opdracht van de operationele diensten van de civiele veiligheid ${ }^{219}$ vallen (meer bepaald de redding en bijstand aan personen in bedreigende omstandigheden en

2I2 Supra nr. 48 .

2 I3 Cass. 9 februari 2006, Pas. 2006, 343.

2I4 Cass. II september 2009, AR C.08.0277.N.

215 Gent 3 september 2009, 2007/AR/1833, onuitg.

2 I6 M. Van Quickenborne, Oorzakelijk verband tussen onrechtmatige daad en schade, Mechelen, Kluwer, 2007, I43.

217 Vred. Sint-Niklaas 22 februari 1999, T.Vred. 2000, 296. De vrederechter voegt er echter aan toe dat de overheid wél vergoed zou moeten worden wanneer een vrijwillige brandstichter zijn kunsten heeft vertoond.

2 I8 BS 3I juli 2007.

2I9 Dit zijn de brandweer- en reddingsposten van de hulpverleningszones en de operationele eenheden van de Civiele Bescherming (art. I Wet 15 mei 2007 betreffend de civiele veiligheid). 
de bescherming van hun goederen, dringende geneeskundige hulpverlening en de bestrijding van brand en ontploffing), ${ }^{220}$ bepaalt een koninklijk besluit of ze gratis moeten worden uitgevoerd, dan wel ten laste van de begunstigde kunnen worden gelegd (artikel 178, paragraaf 2 wet betreffende de civiele veiligheid). Volgens het uitvoeringsbesluit kunnen de kosten van interventies bij schadegevallen, zoals de instorting van een slecht onderhouden schoorsteen, verhaald worden op de begunstigde. Daarentegen zijn de bestrijding van brand en ontploffing, evenals interventies naar aanleiding van een noodoproep om een persoon te redden of te beschermen, altijd gratis. ${ }^{221}$ Artikel 178 , paragraaf 4 preciseert tot slot dat voor de begunstigde personen die de kosten moeten betalen, een beroep openstaat tegen de aansprakelijke derden, overeenkomstig de regels van het gemeen recht.

Hoewel deze wettelijke regeling als zodanig niets zegt over een mogelijk verhaal van de overheid op de aansprakelijke derde, is zij naar onze mening toch van belang voor het antwoord op de vraag of de kosten van bepaalde interventies als een vergoedbare schade kunnen worden beschouwd. Men kan immers aannemen dat interventies die volgens deze regeling 'gratis' zijn, in beginsel definitief voor rekening moeten blijven van de overheid en dus geen vergoedbare schade vormen. Dit zou concreet betekenen dat bijvoorbeeld de kosten van brandbestrijding of van het redden van een persoon in nood, niet verhaald kunnen worden op de persoon die door zijn (niet-opzettelijke) ${ }^{222}$ schuld de oorzaak is van de brand of de noodsituatie.

Vermeldenswaard ten slotte is dat volgens artikel 179 van de wet betreffende de civiele veiligheid, de kosten gemaakt voor de bestrijding van vervuiling en van het vrijkomen van gevaarlijke stoffen ${ }^{223}$ verplicht verhaald moeten worden op de exploitant die de schade of de onmiddellijke dreiging van schade heeft veroorzaakt of op de eigenaar van de gewraakte producten.224 De exploitant of de eigenaar is niet verplicht de kosten te dragen wanneer hij kan bewijzen dat de milieuschade of de onmiddellijke dreiging dat dergelijke schade ontstaat veroorzaakt is door een derde. In dat laatste geval moet een verhaal van de overheid op de aansprakelijke derde

220 Art. II, par. I Wet I5 mei 2007 betreffend de civiele veiligheid.

22I KB 25 april 2007 tot vaststelling van de opdrachten van de hulpdiensten die verhaald kunnen worden en diegene die gratis zijn, BS I4 mei 2007 (gewijzigd bij KB I6 juli 2009, BS 27 augustus 2009).

222 Uit het verslag aan de Koning bij het KB van 25 april 2007 kan men afleiden dat een verhaal van de kosten niet uit te sluiten valt in geval van een opzettelijke fout (bv opzettelijke brandstichting) van de aansprakelijke. Het verslag vermeldt namelijk: 'Naar aanleiding van een opmerking van de Raad van State werd het verhaal van de kosten ten aanzien van de opbeller van een vals alarm en ten aanzien van de dader van een brandstichting geschrapt. Uiteraard blijven de gewone regels inzake burgerlijke aansprakelijkheid hierop van toepassing'. Dat de kosten van interventies die normaal gezien definitief ten laste moeten blijven van de overheid wél een vergoedbare schade uitmaken in geval van een opzettelijke fout, is maatschappelijk verantwoord. Juridisch zou dit verantwoord kunnen worden op grond van het algemeen rechtsbeginsel 'fraus omnia corrumpit'.

223 Dit is met inbegrip van radioactieve stoffen en ioniserende straling (art. II, par. I, $4^{\circ}$ Wet 15 mei 2007 betreffende de civiele veiligheid).

224 Over kostenverhaal door de overheid (na het nemen van ambtshalve maatregelen) in verband met milieuschade, zie R. Slabbinck, 'Implementatie van de Richtlijn Milieuschade: bevoegdheidsverdeling en overzicht van omzettingswetgeving', in: H. Bocken en R. Slabbinck (eds.), Omzetting en uitvoering van de richtlijn milieuschade, Mechelen: Kluwer 2008, (I9) 43-44, 50-57 en 69-70. 
krachtens artikel $1382 \mathrm{BW}$ o.i. mogelijk zijn. Uit de regeling neergelegd in artikel I79 blijkt immers dat het niet de bedoeling is dat de kosten voor de bestrijding van vervuiling en van het vrijkomen van gevaarlijke stoffen definitief ten laste blijven van de overheid.

\section{$5 \quad$ Schade van schuldeisers van het slachtoffer}

\section{I Inleiding}

56. Ook schuldeisers kunnen schade door weerkaatsing lijden, met name wanneer schade wordt berokkend aan de persoon of aan het vermogen van hun schuldenaar en deze laatste daardoor zijn verbintenis niet, niet meer geheel of deugdelijk of niet meer tijdig kan uitvoeren.

Daarbij kan in eerste instantie worden gedacht aan schuldeisers van een contractuele verbintenis, waarbij het kan gaan om geldsomverbintenissen of om verbintenissen om iets te doen. Het kan echter ook gaan om schuldeisers van een verbintenis uit wet (bijvoorbeeld de fiscus) of uit een rechtsfeit (bijvoorbeeld het slachtoffer van een onrechtmatige daad). In die laatste gevallen zal de niet nagekomen verbintenis meestal een geldsomverbintenis zijn.

De vraag rijst of deze afgeleide schade van schuldeisers voor vergoeding in aanmerking komt. Hierna bespreken we eerst de situatie van schuldeisers van andere dan geldsomverbintenissen. Daarna bekijken we de positie van schuldeisers van geldsomverbintenissen. In de rechtsleer blijkt vooral discussie te bestaan over die laatsten, meer bepaald over de vraag of zij een verhaal hebben op de aansprakelijke derde wanneer hun schuldenaar door een fout van deze derde insolvabel wordt.

\subsection{Afgeleide schade van schuldeisers van andere dan geldsomverbintenissen}

57. De afgeleide schade van schuldeisers kan erin bestaan dat de schuldenaar, door de fout van een derde, de beloofde contractuele prestatie (andere dan het betalen van een geldsom) niet meer kan verrichten. Het kan daarbij gaan om gevallen van persoonsschade van de schuldenaar of schade aan zijn goederen.

Gelet op de afwezigheid in het Belgisch recht van elke $a$ priori-beperking van de aanspraakgerechtigden op schadevergoeding, ${ }^{225}$ komt deze schade principieel voor vergoeding in aanmerking. De enige voorwaarde is ook hier dat de schuldeiser kan aantonen dat de schade voldoende zeker is, wat telkens in de feiten zal moeten worden aangetoond. ${ }^{226}$

58. Zo kan een werkgever vergoeding verkrijgen voor de schade die hij lijdt doordat zijn werknemer door de fout van een derde werkonbekwaam wordt en geen

225 Supra, nrs. 5-13.

226 J. Ronse, Schade en schadeloosstelling, in APR, Gent, Story-Scientia, I957, 663-664, nr.I003; E.Dirix, Het begrip schade, I40, nr. 224. 
arbeidsprestaties kan leveren. Dit was van groot praktisch belang onder de vroegere rechtspraak van het Hof van Cassatie, waarin werd geoordeeld dat de contractuele, wettelijke of reglementaire verplichting van de werkgever om het loon van zijn arbeidsongeschikte werknemer verder te betalen, het causaal verband tussen de fout van de derde die deze werkonbekwaamheid veroorzaakt had en de schade verbrak en de doorbetaalde wedde bijgevolg niet voor vergoeding in aanmerking kwam. ${ }^{27}$ Geoordeeld werd toen dat de werkgever wél vergoeding kon bekomen voor de (andere) schade die hij, los van de loondoorbetaling, leed, zoals de nadelen ontstaan uit de verstoring van de dienst of de uitgaven om in de vervanging van de gekwetste werknemer te voorzien. ${ }^{228}$ Omdat het vaak moeilijk is om deze nadelen in concreto aan te tonen, werd zelfs aanvaard dat het verlies van arbeidsprestaties op zich schade uitmaakt. ${ }^{22}$ Sinds 200 I gooit het Hof het over een andere boeg en aanvaardt het dat de tewerkstellende overheid, om recht te hebben op vergoeding, niet dient aan te tonen dat zij een andere schade heeft geleden dan die voortvloeiend uit de doorbetaling van het loon zonder arbeidsprestaties te genieten..$^{230}$ De loondoorbetaling maakt nu op zichzelf vergoedbare schade uit. Dit belet uiteraard niet dat andere schade die de werkgever daarnaast lijdt, zoals schade ingevolge een omzetdaling door het al dan niet tijdelijk verlies van een moeilijk vervangbare (bijvoorbeeld zeer gespecialiseerde) werkkracht, voor vergoeding in aanmerking komt.

59. Nauw verwant met het voorgaande geval, is dat van de vennootschap die schade door weerkaatsing lijdt tengevolge van het overlijden of de arbeidsongeschiktheid van haar (actieve) vennoot. Ook die schade komt voor vergoeding in aanmerking, voor zover zij voldoende zeker is. Zo werd een vordering van een professionele vennootschap die ingevolge een accidenteel overlijden van haar enige vennoot (een arts) in vereffening was gesteld, als ongegrond afgewezen. De rechter achtte geen schade bewezen nu de vennootschap geen wedde of vergoeding diende te betalen en de in vereffeningstelling van de vennootschap een eigen keuze was van de weduwe van de arts, waarvoor alternatieven bestonden. ${ }^{23 \mathrm{I}}$

Ook wanneer de vennootschap, zonder daadwerkelijk schuldeiser te zijn van het slachtoffer, voordeel haalde uit diens activiteiten, is zij gerechtigd op schadevergoeding. Zo vernietigde het Hof van Cassatie een uitspraak die, in een geval waar de door een ongeval getroffen echtgenote van de zakkvoerder van een vennootschap administratief werk verrichtte voor de vennootschap, had beslist dat de vennoot-

227 Supra nr. 48.

228 Cass. 25 maart 1957, Arr.Cass.I957, 6I7 (kosten voor het in dienst nemen van een tijdelijke werkkracht om de goede gang van zaken van de diensten van de gemeente te kunnen verzekeren, zijn vergoedbaar); Cass. 2 december 1977, Arr.Cass. I978, 394 (De Belgische Staat kan aanspraak maken op wat meer werd betaald voor een interim-leerkracht dan wat aan de door een fout van een derde arbeidsongeschikte leerkracht zou zijn betaald).

229 Cass. 9 maart 1999, Arr.Cass. 1999, 346 en Rec.Cass. 2000, 2 1o noot I. Boone.

230 Cass. 9 april 2003, De Verz. 2004, I27, JLMB 2005, I97 noot, Pas. 2003, 765; Cass. Io april 2003, JLMB 2004, 243 noot J.F. Jeunehomme en J. Wildemeersch, Pas.2003, 800, RW 2005-06, I259, noot, RABG 2005, Io8I noot I. Boone.

23I Pol.Charleroi zo november 2006, RGAR 2009, nr. I4465. 
schap geen belang had om schadevergoeding te vorderen omdat zij 'geen juridische of feitelijke band' had met het slachtoffer ${ }^{232}$.

6o. De DCFR gaat ervan uit dat derden, zoals de werkgever of een zakenpartner, die geen nauwe persoonlijke band hebben met het slachtoffer maar die toch nadeel ondervinden als gevolg van de schade berokkend aan het slachtoffer waarmee zij een professionele of zakelijke relatie onderhielden, alleen aanspraak kunnen maken op vergoeding ten laste van de aansprakelijke wanneer hun schade als legally relevant kan worden beschouwd volgens modelregel VI.-2:20I (I) (b) en (c). ${ }^{233}$ Volgens de toelichting is dit alleen in zeer uitzonderlijke gevallen mogelijk, zoals wanneer het slachtoffer door een concurrent van de werkgever of zakenpartner opzettelijk is verwond met de bedoeling deze laatste daardoor nadeel te berokkenen. ${ }^{234}$ Dit wordt bevestigd door (de toelichting bij) modelregel VI.-2:2II, 'Loss upon inducement of non-performance of obligation': er is alleen juridisch relevante schade wanneer de niet-uitvoering van de verbintenis opzettelijk is uitgelokt door een derde, niet wanneer zij door de onzorgvuldigheid van de derde is veroorzaakt. ${ }^{235}$ Op dit punt is het Belgische recht dus duidelijk inschikkelijker.

6r. Ook schade aan goederen van de schuldenaar kan schade door weerkaatsing bij de schuldeiser veroorzaken. Te denken valt bijvoorbeeld aan de in de praktijk frequente gevallen van kabelbeschadiging met weerkaatsingsschade bij klanten van de nutsmaatschappij: een aannemer voert wegeniswerken uit en beschadigt een kabel van een elektriciteitsleverancier waardoor abonnees zonder elektriciteit komen te zitten en schade lijden (omzetschade bij bedrijven, schade aan bederfbare goederen). Er bestaat geen twijfel over dat deze schade in beginsel voor vergoeding in aanmerking komt. ${ }^{236}$

\subsection{Afgeleide schade van schuldeisers van geldsomverbintenissen}

62. Een meerderheidsstrekking in de rechtsleer aanvaardt dat een schuldeiser van een geldsomverbintenis in beginsel ook vergoeding kan vorderen voor de schade die hij lijdt wanneer door de fout van een derde, de schuldenaar niet meer in staat is de verschuldigde som te betalen. Voorwaarde is wel dat de schade voldoende zeker is, wat telkens in de feiten moet worden nagegaan. ${ }^{237}$

232 Cass. Io december 1996, DAOR 199783 noot G.L. Ballon.

233 Zie daarover supra nr. I3.

234 Principles DCFR, Vol. 4, 3224.

235 Principles DCFR, Vol. 4, 3380.

236 Zie bijv. Kh. Kortrijk 27 maart I998, Iuvis 2000, II9I; Vred. Genk I2 mei I998, Iuvis 2003 , I277.

237 L. Cornelis, 'Persoonlijk: over schade en de aansprakelijkheidsvordering van de curator' in Liber Amicorum Yvette Merchiers, Brugge, Die Keure, 200I, 6I-78; R.O. Dalcq, Traité, II, 3I4, nr.3004; D. De Marez, Afgeleide schade van aandeelhouders, 324-353; J.Ronse, Schade en schadeloosstelling, 663-664, nr.1003. Ronse wijst erop dat het voor de schuldeiser van een geldsomverbintenis vaak problematisch zal zijn om aan te tonen dat zijn schade zeker is. Zo zet hij uiteen dat schuldeisers bij overlijden van de schuldenaar hun schuldvordering normaal gezien kunnen verhalen op de erfgenamen, zodat hun situatie door het overlijden niet wezenlijk wordt gewijzigd en zij daar- 
63. Een dissonant geluid is te horen bij Dirix. In navolging van Franse auteurs stelt hij dat bij overeenkomsten intuitu pecuniae ${ }^{23^{8}}$ de schuldeiser geen vergoedbare schade lijdt en dat hem zelfs bij blijvende insolvabiliteit van de schuldenaar die het gevolg is van de fout van een derde, elke vordering tegen de aansprakelijke derde moet worden ontzegd. De reden hiervoor zou zijn dat het risico van de insolvabiliteit van de wederpartij steeds voor rekening moet blijven van de schuldeiser, zonder dat dit op derden mag worden afgewenteld. Dat de schuldeiser onbetaald blijft, heeft hij volgens Dirix enkel aan zichzelf te wijten doordat hij de kredietwaardigheid van zijn medecontractant slecht heeft ingeschat of heeft nagelaten de nodige garanties te bedingen. ${ }^{239}$

Het standpunt van Dirix komt erop neer dat uit de strekking van een intuitu pecuniae aangegane overeenkomst steeds zou volgen dat de schuldeiser het verlies dat hij door de oninbaarheid van zijn vordering lijdt, definitief voor zijn rekening moet nemen, zodat het geen vergoedbare schade is.

Wij menen dat dit niet in zijn algemeenheid kan worden gesteld. De schuldeiser heeft het recht om af te gaan op de actuele solvabiliteit van zijn wederpartij, zonder daarbij rekening te moeten houden met de eventualiteit dat de wederpartij ten gevolge van een onrechtmatige daad van een derde onvermogend wordt. Op basis van die actuele solvabiliteit beslist hij of al dan niet garanties worden gevraagd. ${ }^{240}$ Wel zal het bewijs van het zeker karakter van de schade en van het causaal verband vaak gemakkelijker kunnen worden geleverd wanneer de schuldeiser kan aantonen dat tussen hem en de door de onrechtmatige daad getroffen schuldenaar een rechtsband met een intuitu personae karakter bestond. ${ }^{241}$

door geen schade lijden. Alleen wanneer de nalatenschap deficitair is en door de erfgenamen wordt verworpen én wanneer tegelijk kan worden aangetoond dat het slachtoffer bij leven geleidelijk maar zeker de schuld zou hebben gedelgd, is een vordering tegen de aansprakelijke derde denkbaar.

238 In tegenstelling tot intuitu personae aangegane overeenkomsten. Wanneer dergelijke overeenkomst door de fout van een derde niet kan worden uitgevoerd, is vergoeding van de daaruit voortvloeiende schade volgens Dirix wel mogelijk.

239 E. Dirix, Het begrip schade, I40, nr. 224; E. Dirix, Obligatoire verhoudingen tussen contractanten en derden, 230-23I, nr. 307. In dit laatste werk wordt het standpunt verdedigd dat contractanten slechts over een vordering jegens derden beschikken wegens het verlies/de aantasting van hun contractuele rechten, indien de normale en vrijwillige uitvoering van de overeenkomst door de derde op onrechtmatige wijze wordt doorkruist. Alleen dan zijn contractuele belangen buitencontractueel beschermwaardig. Indien men verder zou gaan en een contractant zou toelaten om de schade die het gevolg is van een normale uitvoering van de overeenkomst af te wentelen op een derde, zou dit een contractuele vordering op de derde verhullen en in strijd zijn met het beginsel van de relativiteit van de overeenkomst neergelegd in artikel II65 BW (zie p. 222-223, nr. 296). Toegepast op het geval waar de schuldenaar ingevolge de onrechtmatige daad van een derde een intuitu pecuniae gesloten overeenkomst niet kan nakomen, acht Dirix dit belang, om de voormelde reden, niet beschermwaardig. De schuldeiser heeft het risico op insolventie van zijn schuldenaar op zich genomen. Het verlies van de schuldeiser kan daarom niet als een 'abnormaal' gevolg van de overeenkomst worden beschouwd.

240 D. De Marez, Afgeleide schade van aandeelhouders, 332.

$24 \mathrm{I}$ D. De Marez, Afgeleide schade van aandeelhouders, 333. De organisator van een toneelvoorstelling zal vrij gemakkelijk kunnen bewijzen dat hij schade lijdt doordat zijn steracteur als gevolg van een verkeersongeval waarvoor een derde aansprakelijk is, niet kan optreden en de voorstelling moet worden afgelast (zie bijv. Brussel 22 januari I955, RCJB I955, I90). Hard maken dat de insol- 
64. Andere dissonante geluiden in verband met de vorderingsmogelijkheid van schuldeisers wegens de oninbaarheid van hun vordering ten gevolge van de fout van een derde, zijn te horen geweest in het raam van het debat over de bevoegdheid van de faillissementscurator om tegen derden aansprakelijkheidsvorderingen in te stellen. Het gaat daarbij meestal om aansprakelijkheidsvorderingen tegen bestuurders van vennootschappen aan wie wordt verweten activa aan de vennootschap te hebben onttrokken of een kennelijk deficitaire activiteit te hebben verdergezet of tegen bankiers aan wie wordt verweten de kredieten onrechtmatig te hebben beëindigd of, omgekeerd, de kredieten te hebben gehandhaafd terwijl de vennootschap ten dode opgeschreven was. ${ }^{242}$ Inzet van de discussie was/is welke aansprakelijkheidsvorderingen, al dan niet exclusief, door de curator kunnen worden ingesteld en welke vorderingen, voor welke schade, door individuele schuldeisers kunnen worden ingesteld. Deze vraag heeft de Belgische rechtsleer en rechtspraak sterk beroerd. ${ }^{243}$

In het bekende UNAC-arrest van I2 februari I98I, ${ }^{244}$ waarvan de leer nadien herhaaldelijk werd bevestigd, ${ }^{245}$ heeft het Hof van Cassatie de bakens uitgezet. ${ }^{246}$ Het Hof heeft daarin de bevoegdheid van de curator, respectievelijk van de schuldeisers om tegen derden aansprakelijkheidsvorderingen in te stellen, afhankelijk gesteld

vabiliteit van de schuldenaar te wijten is aan de fout van een derde en niet aan andere factoren en dat zonder de fout de schuld zou zijn voldaan, zal vaak heel wat moeilijker zijn.

242 Zie voor gevallen van aansprakelijkheid van bestuurders: M. Vandenbogaerde, Aansprakelijkheid van vennootschapsbestuurders, Antwerpen-Oxford, 2009, I33-I37. Zie voor de aansprakelijkheid van de bankier: L. Cornelis, 'De aansprakelijkheid van de bankier bij kredietverlening', TPR I986, 349-404.

243 Zie o.m. T. Bosly 'Préjudice collectif ou individuel: un modèle adéquat pour délimiter les pouvoirs du curateur en des créanciers d'agir en responsabilité contre un tiers?’ noot onder Cass. 5 december 1997, RCJB 2000, 27-58; L. Cornelis, 'Persoonlijk: over schade en de aansprakelijkheidsvordering van de curator' in Liber amicorum Yvette Merchiers, Brugge, Die Keure, 200I, 6I-78; J. Heenen, 'Le curateur peut-il exercer, au nom des créanciers, une action en responsabilité contre un tiers dont la faute a causé une diminution de l'actif ou une aggravation du passif de la masse?' noot onder Cass, I2 februari I98I, RCJB I983, I4-34; J. Vananroye, 'Vorderingsrechten van curator en individuele schuldeisers voor schade aan het vermogen van de gefailleerde', TRV I998, 270-284.

244 Cass. I2 februari I98I, Arr. Cass.ig80-8I, 662, Pas. I98I, I, 639 concl. Declercq, RCJB. I983, I3, noot J. Heenen; TBH. I98I, I54 noot, RPS I98I, II6 noot P. Coppens, JT I98I, 270, JDSC 2000, 239 noot M. Caluwaerts.

245 Cass. 2 maart 1995, Arr.Cass. I995, 247; Pas. I995, I, 250 concl. Liekendael; Cass. 5 december 1997, Arr.Cass. 1997, I289, Pas. I997, I, I355 concl. Spreutels, RCJB 2000, 20 noot T. Bosly, TRV, 1998, 268 noot J. Vananroye; Cass. I9 oktober 1999, Arr.Cass. I999, I295, Pas. 1999, I, I349, TRV 2000, 457 noot J. Vananroye; Cass; 24 oktober 2002, RW 2002-2003, 902 concl. Dubrulle; Cass. 29 oktober 2004, TRV 2005, 554 noot J. Vananroye; RW 2007-08, 500 noot; Cass. I7 december 2008 (F.o6.0079.N), enkel terug te vinden op www.cass.be (alle overige arresten zijn daar ook terug te vinden).

246 Het Hof heeft in dat arrest in de volgende, nadien klassiek geworden bewoordingen, de bevoegdheden van de curator om aansprakelijkheidsvorderingen tegen derden in te stellen, omschreven: 'Overwegende dat de algemene opdracht van de curator erin bestaat de activa van de gefailleerde te gelde te maken en het opgebrachte geld te verdelen. Overwegende dat, wanneer de curator namens de massa in rechte optreedt, hij de gemeenschappelijke rechten van alle schuldeisers uitoefent, maar niet hun individuele rechten; Dat gemeenschappelijke rechten van alle schuldeisers de rechten zijn die voortvloeien uit de schade ten gevolge van de fout van wie ook, waardoor het passief van het faillissement vermeerderd of het actief ervan verminderd wordt; dat wegens de schade die aldus is veroorzaakt aan de massa van goederen en rechten die het gemeenschappelijk pand vormen van de schuldeisers, die fout de oorzaak is van een collectief nadeel voor de schuldeisers en de rechten krenkt die zij uiteraard gemeen hebben.' 
van de aard van de schade die wordt geleden. Het introduceert daartoe het begrip 'collectieve schade', dat het omschrijft als de schade die is veroorzaakt aan de massa van goederen en rechten die het gemeenschappelijk pand vormen van de schuldeisers door een vermindering van het actief of door een vermeerdering van het passief. Deze collectieve schade kan tijdens het faillissement enkel door de curator worden gevorderd. Individuele schuldeisers kunnen tijdens het faillissement geen vergoeding vorderen voor hun aandeel in deze collectieve schade. ${ }^{247}$ Wel kunnen zij andere schade dan collectieve schade, dus schade die niet de weerkaatsing is van schade aan het vermogen van de gefailleerde, vorderen.

Sommige auteurs zien in deze UNAC-rechtspraak een impliciete ontkenning van de 'klassieke' leer, die aan schuldeisers een vorderingsrecht op basis van artikel I382 BW toekent voor afgeleide schade. Volgens hen ontzegt het Hof van Cassatie aan individuele schuldeisers het recht om hun aandeel in de collectieve schade te vorderen omdat het hier gaat om een vorm van schade door weerkaatsing die verdwijnt wanneer de schade van het onmiddellijk getroffen slachtoffer wordt hersteld. Dergelijke schade zou geen persoonlijk karakter hebben voor de schuldeiser. ${ }^{248}$

Wij delen deze zienswijze niet. De UNAC-rechtspraak houdt niet in het algemeen de ontkenning in van een zelfstandig vorderingsrecht van schuldeisers ter vergoeding van patrimoniale weerkaatsingsschade. Het is immers enkel tijdens het faillissement dat aan schuldeisers de mogelijkheid om hun aandeel in de collectieve schade te vorderen wordt ontzegd. ${ }^{249}$ De reden daarvoor wordt door het Hof van Cassatie niet geëxpliciteerd, maar het zijn ongetwijfeld doelmatigheidsredenen ${ }^{250}$ en de collectieve aanpak die eigen is aan een collectieve procedure zoals het faillissement ${ }^{251}$ die daaraan ten grondslag liggen. Na het faillissement hernemen de schuldeisers hun recht om jegens aansprakelijke derden vergoeding te vorderen van

247 Dit werd uitdrukkelijk bevestigd in het arrest van 17 december 2008 (F.o6.0079.N). De commentatoren waren het er voordien in het algemeen al over eens dat de curator tijdens het faillissement exclusief bevoegd is om vergoeding van collectieve schade te vorderen. Zie bijv. T. Bosly 'Préjudice collectif ou individuel: un modèle adéquat pour délimiter les pouvoirs du curateur en des créanciers d'agir en responsabilité contre un tiers?', noot onder Cass. 5 december 1997, RCJB 2000, 4I-43. Bovendien kunnen de schuldeisers tijdens het faillissement ook geen zijdelingse vordering instellen. Cass. 6 januari 1984, Arr.Cass. 1983-84, 507, Pas., I984, I, 480.

248 J. Vananroye, 'Vorderingsrechten van curator en individuele schuldeisers voor schade aan het vermogen van de gefailleerde', 277-278. In dezelfde zin: C. Van Buggenhout en O. Clevenbergh, 'L'action en responsabilité pour 'aggravation du passif', préjudice 'collectif' et cumul de préjudices individuels: tentative d'éclaircissement', 537 .

249 In zijn arrest van 17 januari 2008 beklemtoont het Hof van Cassatie dat een individuele schuldeiser tijdens het faillissement geen vergoeding kan krijgen voor zijn aandeel in de collectieve schade die werd veroorzaakt door de fout van een derde en dat een vordering tijdens het faillissement ingesteld die deze strekking heeft, moet worden afgewezen. Het lijkt er sterk op dat het Hof hiermee laat verstaan dat schuldeisers na faillissement wel hun aandeel in de collectieve schade kunnen vorderen (en dus ook voor faillissement hun afgeleide schade kunnen vorderen).

250 Namelijk de praktische moeilijkheden die zouden ontstaan wanneer zowel curator als individuele schuldeisers zouden kunnen ageren.

25I Waarbij één neutrale vereffenaar-bewindvoerder, namelijk de curator, wordt aangesteld en de individuele actiemogelijkheden van de schuldeisers worden geneutraliseerd (ter vrijwaring van de gelijkheid onder hen). 
hun afgeleide schade, ${ }^{252}$ wat meteen de bevestiging inhoudt dat schuldeisers wel degelijk over een zelfstandig vorderingsrecht voor afgeleide schade beschikken.

Bovendien is de opvatting als zou afgeleide schade van schuldeisers niet vergoedbaar zijn omdat het geen persoonlijke schade is, onjuist. Wanneer een vordering niet kan worden geïnd omdat een derde schade heeft berokkend aan de persoon of het vermogen van de schuldenaar, lijdt de schuldeiser wel degelijk in zijn vermogen schade. Achter de bewering dat de afgeleide schade van de schuldeiser geen persoonlijke schade is, gaat de gedachte schuil dat de weerkaatsingsschade die door een individuele schuldeiser wordt geleden, onvoldoende zeker is om vergoedbaar te zijn omdat de schuldenaar zelf een aansprakelijkheidsvordering kan instellen waarbij de door hem bekomen vergoeding ook de weerkaatsingsschade zal herstellen.253 Hierin kan inderdaad een tweede onuitgesproken reden liggen waarom het Hof van Cassatie tijdens het faillissement aan de curator een exclusief vorderingsrecht toekent voor collectieve schade en aan individuele schuldeisers het recht ontzegt om hun aandeel in de collectieve schade te vorderen: zolang het faillissement duurt, is het mogelijk dat de curator vergoeding vordert voor de collectieve schade en als dat gebeurt, wordt meteen ook de afgeleide schade van de schuldeisers vergoed. Om die reden heeft de eigen schade van de schuldeisers tijdens het faillissement geen voldoende zeker karakter om voor vergoeding in aanmerking te komen. Wanneer het faillissement wordt afgesloten zonder dat de curator een aansprakelijkheidsvordering heeft ingesteld, komt echter met zekerheid vast te staan dat de schade van de schuldeisers niet indirect zal worden vergoed via vergoeding van de schuldenaar zelf en verkrijgt de afgeleide schade een zeker karakter.

65. Uit het voorgaande kunnen we besluiten dat de afgeleide schade van schuldeisers van geldsomverbintenissen wel degelijk voor vergoeding in aanmerking komt. De UNAC-rechtspraak vormt daarvan niet de ontkenning, maar integendeel de bevestiging.

Voor de schuldeisers zal het echter vaak niet eenvoudig zijn om te bewijzen dat hun schade een voldoende zeker karakter heeft. Daarvoor moeten zij aantonen dat de schade niet indirect zal worden hersteld door vergoeding van de schuldenaar en dat de door de schuldenaar opgelopen schade het hem definitief onmogelijk maakt om zijn schuld te voldoen ${ }^{254}$.

252 Dit blijkt impliciet maar zeker uit het arrest van I7 januari 2008 en werd ook voordien al door de meerderheid van de auteurs aanvaard. Zie T. Bosly 'Préjudice collectif ou individuel: un modèle adéquat pour délimiter les pouvoirs du curateur en des créanciers d'agir en responsabilité contre un tiers?', noot onder Cass. 5 december 1997, RCJB 2000, 44; J. Windey, 'Incidence du concordat et de la faillite sur la responsabilité des administrateurs et fondateurs', TBH 200I, 294. Zie ook: Luik 27 januari 2005, RRD 2005, I5I.

253 L. Cornelis, 'Persoonlijk: over schade en de aansprakelijkheidsvordering van de curator', 68-70. Zie in dezelfde zin: D. De Marez, Afgeleide schade van aandeelhouders, 34I-342.

254 R.O. Dalcq, Traité, II, 3004. Dit zal uiteraard gemakkelijker kunnen worden bewezen wanneer de schuldenaar het voorwerp heeft uitgemaakt van een insolventieprocedure die uitmondt in een kwijtschelding van de restschulden (verschoonbaarverklaring na faillissement, kwijtschelding bij collectieve schuldenregeling). 
De afgeleide schade van de schuldeiser zal vaak ook moeilijk te begroten zijn. Die schade is niet zonder meer gelijk aan het bedrag van de schuldvordering of een breukdeel ervan. Er moet rekening worden gehouden met de rangorde van de schuldeisers en met het al dan niet-bestaan van een nettoactief bij de schuldenaar. Indien de schuldenaar al insolvabel was op het ogenblik dat de derde de fout beging, zal de schuldeiser mogelijk geen schade in causaal verband met de fout hebben geleden. Aantonen in welke concrete toestand de individuele schuldeiser zich zou hebben bevonden op het vlak van de invorderbaarheid van zijn schuldvordering indien de fout zich niet zou hebben voorgedaan, zal vaak zeer moeilijk zijn. Eventuele moeilijkheden bij de begroting van de schade laten echter niet toe de vordering af te wijzen. Wanneer de schade zeker is, maar zij niet voor een precieze begroting vatbaar is, dient zij desnoods ex aequo et bono te worden begroot.

Wanneer niet met zekerheid kan worden aangetoond dat zonder de fout van de derde de volledige schuld zou zijn betaald, kan ook de leer van het verlies van een kans goede diensten bewijzen. Hierbij kan worden verwezen naar een arrest van het Hof van Cassatie van 23 februari 2005. In een geval waar vrienden van de hoofdbeklaagde deze laatste hadden geholpen om goederen aan zijn schuldeisers te onttrekken, had de bestreden beslissing deze vrienden veroordeeld tot betaling aan een schuldeiser van een ex aequo et bono begroot bedrag als vergoeding voor het verlies van een kans om voor het faillissement de gehele of gedeeltelijke betaling van zijn vordering te bekomen. Het Hof van Cassatie valideerde deze beslissing. ${ }^{255}$

66. Men kan zich afvragen of de omstandigheid dat schuldeisers die afgeleide schade lijden ook de zijdelingse vordering kunnen instellen tegen de aansprakelijke derde (artikel II66 BW) van enige invloed is op het bestaan van een zelfstandig vorderingsrecht wat hun afgeleide schade betreft. Die vraag moet ontkennend worden beantwoord. Dat de schuldeiser over de mogelijkheid beschikt om de zijdelingse vordering in te stellen, doet geen afbreuk aan zijn recht om de aansprakelijke derde rechtstreeks aan te spreken op grond van artikel I382 BW voor zijn persoonlijke (afgeleide) schade. ${ }^{256}$

67. Bij afgeleide schade van schuldeisers van geldsomverbintenissen kan ten slotte de pauliaanse vordering niet onvermeld blijven. Via deze vordering kunnen schuldeisers, wier schuldvordering reeds bestond op het ogenblik van de gewraakte handeling, in eigen naam opkomen tegen rechtshandelingen die hun schuldenaar heeft

255 Cass. 23 februari 2005, Pas. 2005, I, 442, TBBR 2007, I23. Zie ook Cass. 27 februari 2008 (AR P.07.1567.F), www.cass.be; H. Bocken, 'Geen kans verloren. Causale onzekerheid en de rechtspraak van het Hof van Cassatie over het verlies van een kans', in Aansprakelijkheid, aansprakelijkheidsverzekering en andere schadevergoedingssystemen, Mechelen: Kluwer, 2007 (hierna verkort: 'Geen kans verloren'), (27I) 304, nr. 38.

256 L. Cornelis, 'Persoonlijk: over schade en de aansprakelijkheidsvordering van de curator', 70-7I. De auteur merkt op dat de schadebeperkingsplicht in elk geval niet gebiedt om eerst de zijdelingse vordering in te stellen. De schade wordt voor de aansprakelijke derde niet groter wanneer schuldeisers hun persoonlijke, afgeleide schade vorderen in plaats van de zijdelingse vordering in te stellen. 
verricht met bedrieglijke benadeling van hun rechten. ${ }^{257}$ Er is sprake van benadeling van de schuldeiser wanneer de handeling van de schuldenaar heeft geleid tot diens verarming of tot een vermindering van de verhaalsmogelijkheden van de schuldeiser. Betreft het rechtshandelingen ten bezwarende titel, dan kan de pauliaanse vordering slechts gegrond worden verklaard mits de medeplichtigheid van de medecontractant van de schuldenaar wordt aangetoond.

De pauliaanse vordering wordt door rechtsleer en rechtspraak vastgeknoopt aan de buitencontractuele aansprakelijkheid. De derde die meewerkt aan de bedrieglijke benadeling van de rechten van de schuldeiser, handelt onrechtmatig. De pauliaanse vordering strekt ertoe de schade die door dit onrechtmatig handelen is ontstaan te herstellen. Het herstel bestaat in beginsel hierin dat de gewraakte handeling niet tegenwerpbaar is aan de schuldeiser. Betreft het bijvoorbeeld een verkoop, dan is die overeenkomst de schuldeiser niet tegenwerpbaar en kan hij de verkochte goederen uitwinnen als maakten zij nog deel uit van het vermogen van de schuldenaar. ${ }^{25} 8$ Indien deze vorm van herstel niet mogelijk is, ${ }^{259}$ kan de schuldeiser aanspraak maken op vergoeding van de geleden schade door de derdemedeplichtige. ${ }^{260}$ Uit de verankering van de pauliaanse vordering in het leerstuk van de onrechtmatige daad volgt ook dat de schuldeiser de vordering niet met succes kan instellen wanneer de betwiste rechtshandeling hem geen nadeel heeft berokkend. ${ }^{26 r}$

\subsection{Beperkingen aan de vorderingsmogelijkheden van schuldeisers}

68. Zijn er naar Belgisch recht, benevens de klip van het bewijs van het zeker karakter van de schade en de onmogelijkheid voor individuele schuldeisers om tijdens het faillissement vergoeding te vorderen voor hun aandeel in de collectieve schade, beperkingen aan de mogelijkheid voor schuldeisers om vergoeding van afgeleide schade te vorderen?

69. De eigen fout van de schuldenaar is niet tegenwerpbaar aan de schadelijdende schuldeiser, zoals dat bij naasten het geval is. Eén uitzondering is denkbaar, met name wanneer de schadelijdende schuldeiser tegelijk de aansteller is van de direct benadeelde schuldenaar. Het Hof van Cassatie aanvaardt immers dat bij schade geleden door een aansteller, de derde (mede)aansprakelijke de fout van de aangestelde

257 Art. II67 BW. Zie A. Lenaerts, 'Over de pauliaanse vordering: draagwijdte van de anterioriteitsvoorwaarde en rechtsgevolgen', TBBR 2009, 494-507; W. Van Gerven m.m.v. S. Covemaeker, Verbintenissenrecht, 227-230.

258 E. Dirix, 'De vergoedende functie van de actio pauliana', noot onder Cass. I5 mei I992, RW I992$93,330$.

259 Dit is bijvoorbeeld het geval wanneer het goed dat het voorwerp uitmaakt van de bedrieglijke handeling zich niet meer bij de derde medecontractant bevindt, doordat die laatste dit goed heeft overgedragen aan een derde te goeder trouw.

260 Cass. 25 oktober 200I, Arr.Cass. 200I, I77I en RW 2002-03, 940; Cass. 9 februari 2006, Pas. 2006, 336 en RW 2007-08, I496, noot M.E. Storme.

26I Wanneer bijvoorbeeld zou blijken dat de waarde van het verkochte goed volledig wordt opgeslorpt door het bedrag van de hypothecaire schuldvorderingen, is er geen schade in causaal verband met de gewraakte rechtshandeling en kan de pauliaanse vordering niet worden ingewilligd. 
aan de aansteller kan tegenwerpen. ${ }^{262}$ Dit betekent bijvoorbeeld dat wanneer de aangestelde gekwetst raakt in een ongeval waarvoor hijzelf en een derde medeaansprakelijk zijn, de aansteller de schade die hij lijdt door het derven van prestaties van de aangestelde slechts op de aansprakelijke derde kan verhalen ten belope van diens aandeel in de aansprakelijkheid. ${ }^{263}$

70. Vervolgens rijst de vraag of de aansprakelijke derde argumenten kan putten uit de rechtsverhouding tussen schuldenaar en schuldeiser om aan aansprakelijkheid te ontsnappen.

Kan hij stellen dat uit het bestaan van een exoneratiebeding ten gunste van de schuldenaar blijkt dat de schuldeiser de schade definitief voor zijn rekening moet nemen? Indien, bijvoorbeeld, een nutsmaatschappij zich in haar contract met haar afnemers heeft geëxonereerd voor de schadelijke gevolgen van een stroomonderbreking, kan de aannemer die deze stroomonderbreking veroorzaakte zich daar dan op beroepen om te stellen dat daaruit blijkt dat de schade definitief voor rekening moet blijven van de klant? In de rechtsleer werd reeds verdedigd dat het bestaan van een exoneratiebeding, onder omstandigheden, tot gevolg moet hebben dat aanspraken van de schadelijdende contractant tegen een aansprakelijke derde uitgesloten zouden moeten zijn. ${ }^{264}$ De rechtspraak van het Hof van Cassatie lijkt echter in die zin gevestigd dat het principe van de relativiteit van de overeenkomst zich ertegen verzet dat de aansprakelijke derde zich kan beroepen op een exoneratiebeding in de verhouding tussen de schadelijder en een derde om te stellen dat de schadelijder de schade definitief voor zijn rekening heeft genomen. ${ }^{265}$ Slechts wanneer een dergelijk beding als een beding ten gunste van de aansprakelijke derde kan worden beschouwd, kan die laatste zich erop beroepen.

Vermeldenswaard is hier ook het geval dat leidde tot een arrest van het Hof van Cassatie van 2I mei 2004. ${ }^{266}$ De gebouwen waarin door een pachter een melkexploitatie werd uitgeoefend gingen door de fout van een derde in vlammen op. Het pachtcontract liet de pachter niet toe van de verpachter te eisen dat de gebouwen terug werden opgetrokken. Daarop richtte de pachter zich tegen de aansprakelijke derde en eiste vergoeding van de schade die hij leed door de definitieve stopzetting

262 Cass. 8 september I999, Verkeersrecht 2000, 24; Cass. Io december I999,Verkeersrecht 2000, I29.

263 Zie ook supra nr. 48.

264 Zie E. Dirix, Obligatoire verhoudingen tussen contractanten en derden, 228, nr. 303. De auteur haalt het voorbeeld aan van de stroomonderbrekingsgevallen en verdedigt de oplossing waarbij, in gevallen waarin de nutsmaatschappij zich tegenover de afnemer heeft geëxonereerd, geen aanspraak tegen de aannemer mogelijk is. Dirix stelt: 'Deze oplossing is goed te keuren uit het oogpunt van de aannemer: men komt er immers toe de risico's bij de uitvoering van dergelijke werken binnen zekere perken te houden. De oplossing is ook redelijk t.a.v. de stroomafnemer: door toe te laten dat het energiebedrijf zich exonereert voor stroomonderbreking, neemt hij het risico voor dergelijke storingen - die voor hem geen toevallige omstandigheid meer zijn - op de koop toe en is het aan hem om de passende maatregelen te nemen (bijv. verzekering of inzetten reserve-installatie).'

265 Cass. 27 september I974, Arr.Cass. I975, I25, Pas. I975, I, II3, RW I974-75, 944; Cass. 29 oktober 2004, Arr.Cass. 2004, I715, Pas. 2004, I695, RW 2007-2008, 309, TBBR 2006, 210, noot I. Demortier. Zie over de derdenwerking van exoneratiebedingen: T. Vansweevelt en B. Weyts, Buitencontractueel aansprakelijkheidsrecht, 919-923.

266 Cass. 2I mei 2004, RGAR 2005, nr. 13986 noot F. Glansdorff. 
van de melkexploitatie. De appelrechters wezen de vordering af op grond dat het oorzakelijk verband tussen de brand en de stopzetting van het melkbedrijf zou verbroken zijn door de omstandigheid dat de verpachter contractueel niet verplicht kon worden om de bedrijfsgebouwen her op te richten. De beslissing, die nog steunde op de door het Hof van Cassatie verlaten leer van de verbreking van het oorzakelijk verband, werd, zoals kon worden verwacht, vernietigd. Daardoor kon de reële vraag niet aan bod komen, namelijk of uit de contractuele afspraken tussen pachter en verpachter niet volgde dat de schade definitief voor rekening moest blijven van de pachter. ${ }^{267}$

7I. Een daadwerkelijke beperking voor contractuele schuldeisers om vergoeding te bekomen voor hun afgeleide schade, volgt uit de zogenoemde quasi-immuniteit van aangestelden, uitvoeringsagenten en organen. Deze jurisprudentiële regel werd sinds het begin van de jaren zeventig door het Hof van Cassatie ontwikkeld. ${ }^{268}$ Kort samengevat komt het erop neer dat aangestelden en uitvoeringsagenten waarop een schuldenaar beroep doet voor het geheel of gedeeltelijk uitvoeren van zijn contractuele verbintenissen, ten aanzien van de opdrachtgever en voor wat de uitvoering van de overeenkomst betreft, niet als derden worden beschouwd en dus worden gelijkgesteld met de schuldenaar. Eind jaren negentig werd deze regel uitgebreid tot organen van private rechtspersonen. ${ }^{269}$

Uit deze regel volgt dat aangestelden, uitvoeringsagenten en organen voor fouten begaan bij de uitvoering van het contract slechts op buitencontractuele grond kunnen worden aangesproken onder de zelfde voorwaarden waaronder de hoofdschuldenaar zelf op buitencontractuele grond kan worden aangesproken. ${ }^{270}$ Dat laatste is, behoudens wanneer het een misdrijf betreft, slechts het geval wanneer de bij de uitvoering van het contract begane fout niet alleen een tekortkoming uitmaakt aan een contractuele verbintenis, maar ook aan de eenieder opgelegde algemene zorgvuldigheidsnorm en wanneer daaruit andere dan uit de slechte uitvoering van de overeenkomst voortvloeiende schade volgt. ${ }^{271}$ Een en ander heeft tot gevolg

267 Zie M. Van Quickenborne, 'Overzicht van rechtspraak. Aansprakelijkheid uit onrechtmatige daad 2000-2007. Deel I Oorzakelijk verband ( . )', TPR 2010, 358. Toepassing makend van het door Dirix ontwikkelde criterium, stelt deze dat de reële vraag was of de nalatige brandstichter door zijn fout de normale werking van de pachtovereenkomst had verstoord.

268 Cass. 7 december 1973, Arr.Cass. 1974, 395, concl. P. Mahaux, RW 1973-74, I597, noot J. Herbots, RGAR I974, nr. 9.317, noot J.-L. Fagnart, RCJB I976, I5, noot R.O. Dalcq en F. Glansdorffen T. Aann. I975, I8I, noot A. Limpens-Meinertzhagen. Zie nadien Cass. 8 april I983, Arr.Cass. I982-83, 934 en RW I983-84, noot J. Herbots; Cass. 26 oktober I990, Arr. Cass. I990-9I, 244 en RCJB I992, 497, noot R.O. Dalcq; Cass. 23 mei I997, Arr.Cass. I997, 563; Cass. I juni 200I, AJT 200I-02, 358 noot I. Boone en S. Mosselmans. Zie I. Claeys, Samenhangende overeenkomsten en aansprakelijkheid. De quasi-immuniteit van de uitvoeringsagent herbekeken, Antwerpen-Groningen-Oxford, Intersentia, 2003, I43-238; zie i.h.b. voetnoot 529 op p. I43 voor een overzicht van de uitvoerige rechtsleer (tot 2003).

269 Cass. 7 november 1997, Arr.Cass. 1997, 1093.

$270 \mathrm{Zij}$ kunnen uiteraard ook niet op contractuele basis worden aangesproken omdat zij geen partij zijn bij het contract tussen opdrachtgever en hoofdschuldenaar. Het is alleen voor wat de uitvoering van het contract betreft, dat zij met de hoofdschuldenaar worden geïdentificeerd.

27 I Cass. 29 september 2006, RW 2006-2007, I7I7 noot A. Van Oevelen, NjW 2006946 noot I. Boone; Cass. 7 juni 20Io, AR C.09.0586.N. 
dat aangestelden, uitvoeringsagenten en organen van de hoofdschuldenaar quasiimmuun zijn voor vorderingen van de opdrachtgever.

Vermits de schade die de hoofdschuldenaar lijdt doordat zijn uitvoeringsagent/ aangestelde/orgaan diens contract met de opdrachtgever niet correct uitvoert, uiteraard steeds afstraalt op de opdrachtgever, is dit meteen de meest in het oog springende beperking op de verhaalbaarheid van afgeleide schade van schuldeisers naar Belgisch recht.

In het bijzonder moet daarbij nog worden opgemerkt dat de uitbreiding van de leer van de quasi-immuniteit tot organen van private rechtspersonen de vraag heeft doen rijzen of (contractuele) schuldeisers van een (insolvabele) vennootschap zich nog op buitencontractuele grond kunnen richten tegen de bestuurders van deze vennootschap (bijvoorbeeld wegens het onzorgvuldig verderzetten van een deficitaire, reddeloos verloren activiteit) ter recuperatie van hun onbetaald gebleven vordering op de vennootschap. Sommige auteurs hebben daarop ontkennend geantwoord, omdat het onbetaald blijven van een contractuele vordering steeds contractuele schade zou zijn die, krachtens het principe van de quasi-immuniteit, niet op buitencontractuele grond tegen de bestuurder zou kunnen worden gevorderd. ${ }^{272}$ Ons inziens terecht is hierop gerepliceerd dat deze redenering niet opgaat, omdat de bestuursfout die in dergelijke gevallen doorgaans aan de bestuurder verweten wordt niet werd begaan in de uitvoering van een bepaald contract, maar eerder het algemeen beleid van de vennootschap betreft. ${ }^{273}$

\section{Schade van aandeelhouders}

\section{I Inleiding}

72. Wanneer door de fout van een - al dan niet contractueel met de vennootschap verbonden - derde schade wordt toegebracht aan het vermogen van de vennootschap, kan dit een negatieve weerslag hebben op de waarde van de aandelen in de vennootschap. De vraag rijst dan of een individuele aandeelhouder vergoeding kan vorderen voor de schade die hij daardoor lijdt. Ook die schade is een vorm van afgeleide schade: de aandeelhouder lijdt schade als gevolg van het feit dat het directe slachtoffer, de vennootschap, schade lijdt.

272 X. Dieux, 'La responsabilité des administrateurs ou gérants d'une personne morale à l'égard des tiers: une révolution de velours' in Mélanges John Kirckpatrick, Brussel, Bruylant, 2004, 234. Alleen in de gevallen waar het vennootschapsrecht in een bijzondere aansprakelijkheid van de bestuurders voorziet, zou dergelijke vordering wél nog mogelijk zijn. Zie ook M. Coipel, 'La responsabilité quasi-délictuelle des gérants d'une SPRL en raison de la poursuite déraisonnable d'une activité irrémédiablement condamnée', noot onder Luik, I9 oktober 2004, TBH 2006, 43I. In dit arrest wordt beslist dat de vordering ingesteld door de curator niet stuit op de quasi-immuniteit van de bestuurders omdat de curator de schade geleden door de massa van de schuldeisers vordert, die zowel uit contractuele als niet-contractuele schuldeisers bestaat.

273 P.A. Foriers, 'Responsabilité personelle des organes, mandataires, préposés et agents d'exécution. Responsabilité du fait d'autrui', in P. Van Ommeslaghe (ed.), Actualité en droit de la responsabilité, Brussel, Bruylant, 2010, 72, nr. I3. 


\subsection{De klassieke leer: aandeelhouders hebben geen zelfstandig vorderingsrecht voor afgeleide schade}

73. Voor vennootschappen met volkomen rechtspersoonlijkheid, ${ }^{274}$ waaronder de $\mathrm{NV}$ en de BVBA, wordt deze vraag traditioneel ontkennend beantwoord. ${ }^{275}$ Volgens de klassieke leer beschikken individuele aandeelhouders niet over een zelfstandig vorderingsrecht om vergoeding van dergelijke schade na te streven. ${ }^{276}$ De argumenten daarvoor worden zowel uit het gemeen aansprakelijkheidsrecht als uit het vennootschaps- en rechtspersonenrecht geput.

74. Vanuit het aansprakelijkheidsrecht wordt gesteld dat aan de aandeelhouders geen zelfstandig vorderingsrecht voor afgeleide schade toekomt. Deze schade zou niets anders zijn dan schade van de vennootschap zelf, die alle aandeelhouders op gelijke wijze treft in verhouding tot hun participatie, die zij maar lijden in hun hoedanigheid van vennoot en die verdwijnt wanneer de schade van de vennootschap wordt hersteld. Ook wanneer de vennootschap zou beslissen om geen vergoeding te vorderen voor de geleden schade, dient aan de aandeelhouder een zelfstandig vorderingsrecht te worden ontzegd. De beslissing van de vennootschap om geen vergoeding te vorderen bindt de vennoten. Hun afgeleide schade zou dan haar oorzaak vinden in deze beslissing, niet in de fout van de derde. ${ }^{277}$

75. In de vennootschapsrechtelijke literatuur wordt de afwezigheid van een zelfstandig vorderingsrecht van individuele aandeelhouders voor afgeleide schade verklaard

274 Daarmee zijn bedoeld de vennootschapsvormen met rechtspersoonlijkheid waarin de aansprakelijkheid van de vennoten beperkt is tot hun inbreng, met andere woorden waar de vennoten in principe niet kunnen worden aangesproken voor de schulden van de vennootschap. Het gaat met name om de naamloze vennootschap (NV), de besloten vennootschap met beperkte aansprakelijkheid (BVBA), de commanditaire vennootschap op aandelen (Comm.VA) en de coöperatieve vennootschap met beperkte aansprakelijkheid (CVBA).

275 Voor vennootschappen zonder rechtspersoonlijkheid (nl. de maatschap, de tijdelijke vennootschap en de stille vennootschap) of met onvolkomen rechtspersoonlijkheid (wel rechtspersoonlijkheid maar geen beperkte aansprakelijkheid van de vennoten, nl. de vennootschap onder firma (VOF), de gewone commanditaire vennootschap (Comm.V) en de coöperatieve vennootschap met onbeperkte aansprakelijkheid (CVOA)), wordt traditioneel aangenomen dat de vennoten voor eigen rekening een aansprakelijkheidsvordering kunnen instellen tegen het bestuur (J. Ronse, Algemeen deel van het vennootschapsrecht, Leuven, Acco, I975, 462-463, J. Vananroye, 'Zelfstandige vorderingsrechten', 246-247. Contra (voor de VOF en de Comm.V): V. Simonart, La personalité morale en droit privé, Brussel, Bruylant, I995, 443-444). De verklaring die hiervoor wordt gegeven is dat in dergelijke vennootschappen, waarin het intuitu personae-karakter sterk aanwezig is, een lastgevingsrelatie zou bestaan tussen de vennoten zelf en het bestuur.

276 Zowel de klassieke auteurs die het probleem (weliswaar meestal zeer summier) vanuit het gemeen aansprakelijkheidsrecht benaderen, als de auteurs die de problematiek benaderen vanuit het vennootschapsrecht, komen tot deze conclusie. Zie voor het aansprakelijkheidsrecht bijvoorbeeld: R. Dalcq, Traité, II, nrs. 2996-2997; E. Dirix, Het begrip schade, Ioo, nr.I48; zie voor het vennootschapsrecht bijvoorbeeld: J. Van Ryn, Principes de droit commercial, T.I, Brussel, Bruylant, 1954, 396-399; L.Fredericq, Traité de droit commercial belge, T.IV, Gent, Fechyr, 1950, 434; J. Ronse, Algemeen deel van het vennootschapsrecht, Leuven Acco, I975, 46I-462; K. Geens, M. Denef, F. Hellemans, R. Tas en J. Vananroye, 'Vennootschappen. Overzicht van rechtspraak (I992-I998), TPR 2000, 306, nr. 267.

277 R. Dalcq, Traité, II, nr. 2997. 
vanuit de rechtspersoontechniek. De vennootschappelijke rechtspersoon als afzonderlijk rechtssubject schermt zowel zijn rechten als plichten af van de vermogens van zijn leden. De afwezigheid van een zelfstandig vorderingsrecht is, vanuit die optiek, de keerzijde van de beperkte aansprakelijkheid van de aandeelhouders.

76. Meer recent werden aan deze traditionele verantwoording nog een aantal argumenten toegevoegd. ${ }^{278}$

Er wordt gewezen op het feit dat een efficiënt vennootschapsbestuur vereist dat de vordering geconcentreerd wordt bij (het bevoegde orgaan van) de vennootschap. Het management kan doorgaans beter dan de individuele aandeelhouder beoordelen of het instellen van een vordering opportuun is. Een evident gegronde schadevordering kan onder omstandigheden beter niet worden ingediend indien dit een belangrijke commerciële relatie in gevaar kan brengen.

Voorts wordt erop gewezen dat de aansprakelijkheidsvordering een vennootschapsgoed is waarop de normale regels inzake het bestuur van de vennootschap van toepassing zijn. Het provenu van de vordering komt aan de vennootschap toe en over de bestemming ervan moet worden beslist conform de geëigende regels van het vennootschapsrecht. Een zelfstandig vorderingrecht voor individuele aandeelhouders zou economisch gezien neerkomen op een dividenduitkering zonder dat het bestuur of de algemene vergadering hierin tussenkomt.

Het ontzeggen van een vorderingsrecht aan de individuele aandeelhouders zou ook noodzakelijk zijn ter bescherming van de rechten van de vennootschapsschuldeisers. De aanspraak op schadevergoeding is een actiefbestanddeel van de vennootschap, op wiens vermogen de schuldeisers bij voorrang gerechtigd zijn. De aandeelhouders kunnen slechts aanspraak maken op het eventueel saldo na vereffening. Door een zelfstandig vorderingsrecht toe te kennen aan aandeelhouders worden zij echter in plaats van postconcurrente schuldeisers, schuldeisers met een supervoorrecht.

Door de aansprakelijkheidsvordering te concentreren bij de vennootschap worden de transactie- en proceskosten beperkt, terwijl een versplintering van de vordering over de aandeelhouders deze kosten vermenigvuldigt. Hoe meer partijen, des te kleiner de kansen op een akkoord buiten het gerecht om en des te groter de kosten indien het tot een proces komt.

Ten slotte wordt erop gewezen dat de schade aan het vennootschapsvermogen veel gemakkelijker vast te stellen is dan de waardevermindering die een aandeel als gevolg daarvan ondergaat. De schade van de aandeelhouder is zeker niet zomaar altijd de schade aan de vennootschap gedeeld door zijn participatie in het kapitaal. Dit miskent immers dat aandeelhouders slechts gerechtigd zijn op het

278 J. Vananroye, 'Zelfstandige vorderingsrechten van aandeelhouders voor schade aan het vennootschapvermogen' in Beginselen van vennootschapsrecht in binationaal perspectief. Vergelijkende beschouwingen naar Belgisch en Nederlands recht, H.J. De Kluyver en J. Wouters (eds.), Intersentia, Antwerpen-Groningen, 1998 (hierna verkort 'Zelfstandige vorderingsrechten'), 235 e.v. (238239); J. Vananroye, 'Actiemogelijkheden van aandeelhouders inzake bestuurdersaansprakelijkheid' in De strafrechtelijke aansprakelijkheid van de rechtspersoon en zijn bestuurders, M. Faure en K. Schwarz (eds.), Intersentia, Antwerpen-Groningen, I998, I97 e.v. (220-227). 
vennootschapsvermogen nadat de aanspraken van de vennootschapsschuldeisers zijn voldaan. Indien de vennootschap een nettopassief heeft, wat going concern bovendien niet altijd gemakkelijk vast te stellen is, zal de schade voor de aandeelhouder enkel bestaan in het verlies van een kans op herstel. Een zelfstandig vorderingsrecht van aandeelhouders zou derhalve, naast een waardering van de schade aan de vennootschap, nopen tot een moeilijke waardering van de vennootschap zelf. ${ }^{279}$

77. De Belgische rechtspraak volgt de traditionele visie dat individuele aandeelhouders niet beschikken over een zelfstandig vorderingsrecht tegen de aansprakelijke derde ter vergoeding van afgeleide schade. Nagenoeg alle gepubliceerde uitspraken hebben betrekking op vorderingen van aandeelhouders tegen bestuurders van de vennootschap. ${ }^{280}$ Vanuit deze vaststelling moet worden opgemerkt dat de discussie aan belang heeft ingeboet sinds, bij wet van I8 juli I99I, de minderheidsvordering in het Belgisch vennootschapsrecht werd ingevoerd. De minderheidsvordering laat aandeelhouders die een bij wet bepaalde minimumparticipatie in de vennootschap bezitten ${ }^{281}$ en die de door de algemene vergadering aan de bestuurders verleende kwijting niet mee hebben goedgekeurd, toe om voor rekening van de vennootschap de actio mandati, dus de vordering van de vennootschap tegen bestuurders wegens fouten begaan bij de uitoefening van hun bestuursmandaat, in te stellen. ${ }^{282}$ Het gaat hierbij om een vorm van zijdelingse vordering, ${ }^{283}$ die voor rekening van de vennootschap wordt ingesteld en waarvan het provenu toekomt aan

279 Voor Vananroye is het dus niet zozeer de rechtspersoonlijkheid van de vennootschap, maar vooral een efficiënt vennootschapsbestuur en de bescherming van de vennootschapscrediteuren die aan een zelfstandig vorderingsrecht van aandeelhouders voor afgeleide schade in de weg staan. Hij meent daarom dat de regel ook moet gelden voor vennootschappen zonder rechtspersoonlijkheid of met onvolkomen rechtspersoonlijkheid. Zie J. Vananroye, 'Zelfstandige vorderingsrechten', 244-245.

280 Luik 9 september 2004, JT 2005, 85; Rb. Kortrijk 27 september I979, RPS I980, 70; Rb. Antwerpen 2I juni I966, RPS I967, II2; Kh. Brussel, 6 juni 1977, RPS I977, 202; Kh. Brussel, I februari I935, RPS I935, I70.

28I Voor de N.V. bijvoorbeeld, staat de minderheidsvordering open voor de aandeelhouders die op de dag dat de algemene vergadering van aandeelhouders zich uitspreekt over de aan de bestuurders te verlenen kwijting, effecten bezit die ten minste één procent vertegenwoordigen van de stemmen verbonden aan het geheel van de op die dag bestaande effecten of op diezelfde dag effecten bezitten die een gedeelte van het kapitaal vertegenwoordigt ter waarde van ten minste I.250.000 euro (art. 562 W.Venn.).

282 Zie over de minderheidsvordering, onder meer: O. Ralet, 'La responsabilité des administrateurs et l'action minoritaire', DAOR I99I, 49-60; H. Laga, 'De minderheidsvordering en het deskundigenonderzoek', in NV en BVBA na de wet van 18 juli 1991, Reeks Rechtspersonen- en Vennootschapsrecht, Kalmthout, Biblio, I992, 217-242. H. Braeckmans, 'De nieuwe vennootschapswet van I8 juli I99I', RW I99I-I992, I046-I050, nr. 50-65.

283 Aangenomen wordt dat aandeelhouders niet beschikken over de mogelijkheid om via de zijdelingse vordering (voorzien in art. II66 BW) schuldenaars van de vennootschap aan te spreken wanneer de vennootschap zelf blijft stilzitten. De zijdelingse vordering staat immers enkel open voor schuldeisers en aandeelhouders kunnen niet als schuldeisers van de vennootschap worden beschouwd (behoudens in het geval waar is beslist tot een dividenduitkering en deze uitkering niet gebeurt). Wat de vordering tegen bestuurders betreft, zou de zijdelingse vordering overigens stoten op de, bij veronderstelling, door de vennootschap aan de bestuurders verleende kwijting. Het is precies dit bezwaar dat via de minderheidsvordering opzij wordt gezet. Op dit punt verschilt zij dus van de zijdelingse vordering. 
de vennootschap, niet aan de vorderende aandeelhouder. Het gaat dus niet om een wettelijk geregeld individueel vorderingsrecht van aandeelhouders.

De discussie of een zelfstandig vorderingsrecht aan individuele aandeelhouders moet worden toegekend, blijft echter haar volle relevantie behouden voor vorderingen tegen bestuurders van aandeelhouders die niet aan de voorwaarden voldoen om een minderheidsvordering te kunnen instellen en, uiteraard, voor aansprakelijkheidsvorderingen tegen andere derden dan bestuurders. In de gepubliceerde rechtspraak zijn daarvan echter geen voorbeelden terug te vinden.

\subsection{Nieuwe strekking: wel een zelfstandig vorderingsrecht voor individuele aandeelhouders}

78. Meer recent tekent zich in de rechtsleer een strekking af die de traditionele visie bestrijdt en die, op basis van een analyse die vertrekt vanuit het gemeen aansprakelijkheidsrecht, de stelling verdedigt dat een individueel vorderingsrecht voor afgeleide schade tegen een aansprakelijke derde niet $a$ priori aan individuele aandeelhouders kan worden ontzegd. ${ }^{284}$

In essentie komt deze stelling erop neer dat de waardevermindering die aandelen ondergaan ten gevolge van de fout van een derde (contractueel betrokken derde of loutere derde) wel degelijk schade is die zich manifesteert in het vermogen van de aandeelhouder en dus een persoonlijk karakter heeft. Aangezien het echter schade betreft die verdwijnt wanneer het rechtstreekse slachtoffer (de vennootschap) wordt vergoed, verwerft deze schade slechts een zeker karakter en komt zij pas voor vergoeding in aanmerking vanaf het ogenblik waarop met afdoende zekerheid komt vast te staan dat de vennootschap zelf geen schadevergoeding meer zal verkrijgen en de afgeleide schade van de aandeelhouder dus niet meer onrechtstreeks zal worden hersteld. Dit is bijvoorbeeld het geval wanneer de vennootschap uitdrukkelijk afstand heeft gedaan van haar recht om tegen de aansprakelijke een vordering in te stellen, ${ }^{285}$ wanneer de vordering van de vennootschap verjaard is of vervallen of

284 D. De Marez, Afgeleide schade van aandeelhouders, 276-323. De daarin ontwikkelde stelling wordt bijgetreden door K. Grillet, 'Verantwoordelijkheid vennootschap en bestuurders. Schadevergoeding voor individuele aandeelhouders wegens waardevermindering van aandelen' $\mathrm{NjW} 2007$, I46-I59. Dat aandeelhouders over een zelfstandig vorderingsrecht beschikken werd ook in oudere rechtsleer al verdedigd: J. Kirkpatrick, 'La responsabilité des administrateurs de société anonyme à l'égard de chaque actionaire en droit positif belge', RPS ig64, I-I6.

285 Wat de aansprakelijkheidsvorderingen tegen bestuurders/zaakvoerders en commissarissen van de vennootschap betreft, volgt dergelijke afstand uit de aan de bestuurders en commissarissen verleende kwijting. Daarbij zou nog de vraag kunnen worden gesteld of de schade van de individuele aandeelhouder niet pas een zeker karakter verwerft wanneer vast staat dat geen van de andere aandeelhouders de minderheidsvordering zal instellen. De Marez beantwoordt een gelijklopende vraag, nl. of de schade van de individuele aandeelhouder niet pas een zeker karakter verkrijgt wanneer vast staat dat geen enkele schuldeiser bij wege van de zijdelingse vordering voor rekening van de vennootschap een aansprakelijkheidsvordering tegen de derde zal instellen, ontkennend. Daartoe wordt aangehaald dat de rechter bij het beoordelen van het zeker karakter van de schade van de aandeelhouder moet uitgaan van de concrete situatie en geen rekening moet houden met louter theoretische hypotheses die zich zouden kunnen voordoen maar die niet overeenstemmen met de normale gang van zaken: het behoort tot de normale gang van zaken dat de schadelijdende vennootschap zelf vergoeding vordert jegens de aansprakelijke, 
nog wanneer de vennootschap met de aansprakelijke een dading sluit waardoor de schade niet op adequate wijze werd vergoed. ${ }^{286}$

79. De auteurs van deze strekking wijzen de door de klassieke visie aangevoerde argumenten om een zelfstandig vorderingsrecht aan aandeelhouders te ontzeggen van de hand.

In de eerste plaats wijzen zij erop dat de opportuniteitsargumenten - zoals de moeilijkheid om de schade van de aandeelhouder te begroten, de grotere transactie- en proceskosten en het feit dat het management van de vennootschap beter dan een individuele aandeelhouder kan beoordelen of het (ook commercieel gezien) opportuun is om een aansprakelijkheidsvordering in te stellen tegen een derde geen juridische reden kunnen zijn om een vorderingsrecht aan de aandeelhouder te ontzeggen.

Voorts wijzen zij erop dat het toekennen van een eigen vorderingsrecht aan de individuele aandeelhouder geen benadeling van de vennootschapsschuldeisers teweegbrengt. De vordering tot het bekomen van schadeloosstelling voor de door de aandeelhouder geleden afgeleide schade tast op zich het vennootschapsvermogen niet aan en evenmin ontvangt de aandeelhouder iets wat de vennootschap en haar schuldeisers zou toekomen. De afgeleide schade van de aandeelhouder is immers maar zeker en vergoedbaar wanneer vast staat dat de vennootschap zelf niet zal worden vergoed.

Ten slotte stellen zij dat de loutere omstandigheid dat de aandeelhouder de onderscheiden rechtspersoonlijkheid van de vennootschap en de in de schoot ervan genomen beslissingen moet respecteren, niets afdoet aan de eigen patrimoniale rechten van de aandeelhouder. Het is niet omdat vele vennootschapsbeslissingen repercussies hebben op de waarde van de aandelen en dat de aandeelhouders hiertegen vaak geen enkel verhaal hebben, dat als algemene regel zou gelden dat aandeelhouders zich zonder meer bij elke waardevermindering van hun participatie moeten neerleggen. Het toetreden tot een vennootschap houdt niet in dat de aandeelhouder $a$ priori afstand doet van zijn vorderingsrechten op basis van het gemeen aansprakelijkheidsrecht.

\subsection{Eigen visie}

8o. De strekking die individuele aandeelhouders een zelfstandig vorderingsrecht toekent voor de afgeleide schade bestaande in de waardevermindering van hun aandelen tengevolge van onrechtmatig gedrag van een derde, is zeker niet onaantrekkelijk. Toch rijst de vraag of de afgeleide schade van een aandeelhouder die niet vergoed geraakt via vergoeding van de vennootschap zelf, als vergoedbare schade

maar niet dat een schuldeiser dit langs zijdelingse weg doet. Zie D. De Marez, Afgeleide schade van aandeelhouders, 314-3I5.

286 Volgens De Marez moet er echter in beginsel worden van uitgegaan dat door een dading tussen vennootschap en aansprakelijke de schade van de vennootschap en dus ook de afgeleide schade van de aandeelhouder wordt vergoed. Zie D. De Marez, Afgeleide schade van aandeelhouders, 3 II. 
kan worden beschouwd en of de belangen die hier worden geschonden wel in aanmerking dienen te komen voor bescherming door het aansprakelijkheidsrecht. Is het niet toch zo dat de rechtsverhouding tussen aandeelhouder en vennootschap inhoudt dat het de vennootschap is die, op grond van motieven die haar eigen zijn, beslist of een aansprakelijkheidsvordering tegen een derde wordt ingesteld, dat een aandeelhouder tegen de beslissing om dat al of niet te doen kan opkomen via de middelen die het vennootschapsrecht hem ter beschikking stelt (onder andere de minderheidsvordering voor de aansprakelijkheidsvordering tegen de bestuurders), maar dat indien hij er niet in slaagt om de vennootschap tot het instellen van een aansprakelijkheidsvordering te bewegen of de schade aan de vennootschap te herstellen, hij zich daarbij heeft neer te leggen? Men kan met andere woorden verdedigen dat in de hier beschreven situatie uit de strekking van de rechtsverhouding tussen vennootschap en aandeelhouder volgt dat de eventuele schade van de aandeelhouder door de waardevermindering van zijn aandelen definitief voor zijn rekening moet blijven en dus geen vergoedbare schade uitmaakt. Dit zou alvast, vanuit het gemeen aansprakelijkheidsrecht, een verantwoording kunnen zijn voor de klassieke visie, die een zelfstandig vorderingsrecht aan aandeelhouders ontzegt.

\subsection{Bijzondere schade}

8r. Terwijl onenigheid bestaat over de vraag of een individuele aandeelhouder een zelfstandig vorderingsrecht heeft voor afgeleide schade, is men het erover eens dat een aandeelhouder wel vergoeding kan vorderen voor bijzondere schade, dit is schade veroorzaakt door onrechtmatige gedragingen die niet het vermogen van de vennootschap, maar rechtstreeks het vermogen van de aandeelhouder hebben aangetast.

Het klassieke voorbeeld van dergelijke bijzondere schade is de schade van de aandeelhouder die zijn aandelen gekocht heeft op basis van onjuiste/vervalste informatie verstrekt door bestuurders/commissarissen van de vennootschap. ${ }^{287}$ De aandeelhouder heeft dan een vorderingsrecht tegen de verantwoordelijke bestuurders en commissarissen. De aan hen verweten fout veroorzaakt immers geen schade aan het vermogen van de vennootschap. Zij leidt enkel tot schade aan het vermogen van de kopers van de aandelen. ${ }^{288}$ In de welbekende Lernout en Hauspie-zaak ${ }^{289}$ bijvoor-

287 J. Vananroye, 'Zelfstandige vorderingsrechten', 248. Zie in deze zin Cass. 26 januari I922, Pas. I922, I, I43.

288 Ook al zal deze schade zich pas veruitwendigen wanneer het vermogen van de vennootschap zelf aftakelt en het tot faillissement van de vennootschap komt. De fout van de bestuurders/ commissarissen heeft in de hier beschouwde hypothese (verstrekken onjuiste informatie) de schade aan het vennootschapsvermogen niet veroorzaakt. Hierin ligt het verschil met gevallen van afgeleide schade, waar de aan de derde verweten fout schade aan het vermogen van de vennootschap heeft veroorzaakt.

289 Lernout \& Hauspie was een spraaktechnologiebedrijf gevestigd in Ieper in de zogenoemde Flanders Language Valley waar ook verwante bedrijven zich hadden gevestigd. Het speelde een rol in de ontwikkeling van spraakherkenning en spraaksynthese. Het bedrijf kwam in opspraak na onderzoek door de The Wall Street Journal omtrent het bestaan van spookbedrijven en boekhoudkundige onregelmatigheden met het doel de koers van de aandelen de hoogte in te jagen. De aandelen van het bedrijf kelderden in nauwelijks een half jaar tijd en uiteindelijk ging Lernout \& Hauspie failliet in 200I. Het bedrijfliet gigantische putten na plus een peleton schuldeiser, waar- 
beeld, vorderen de aandeelhouders vergoeding van de (bijzondere) schade die zij hebben geleden doordat zij, afgaand op de volgens hen onjuiste/vervalste informatie die door het bedrijf werd verspreid, aandelen hebben gekocht.

82. In ditverband kan erop worden gewezen dat de DCFR(VI.-2:207) schade die wordt veroorzaakt doordat een persoon op basis van een redelijk vertrouwen op onjuiste informatie een beslissing neemt, als legally relevant beschouwt op voorwaarde dat de onjuiste informatie wordt verstrekt door een professioneel of in het kader van de handel en wanneer degene die de informatie verstrekt weet of redelijkerwijze moet weten dat de ontvanger van de informatie daarop zal vertrouwen om een beslissing te nemen. Als voorbeeld wordt het geval vermeld waarbij accountants, die de boeken van een bedrijf controleren, een aanzienlijk verlies over het hoofd zien en particulieren op basis van hun rapporten investeren in het bedrijf, dat kort nadien over de kop gaat. ${ }^{290}$

\section{$7 \quad$ Weerslagschade van overige derden}

83. Behalve naasten en nabestaanden, schuldenaars, schuldeisers en aandeelhouders van de rechtstreeks getroffene, die eerder als specifieke categorieën van 'derdeschadelijders' zijn behandeld, kunnen nog andere personen schade lijden als gevolg van de onrechtmatige aantasting van de fysieke integriteit, de goederen, het vermogen of de persoonlijkheidsrechten van het onmiddellijke slachtoffer. Deze 'restcategorie' is uit haar aard eindeloos en bijzonder divers. We beperken ons daarom tot enkele typegevallen.

84. Een typisch voorbeeld is de eigenaar van een hotel die omzetverlies lijdt doordat een nabijgelegen bos in strijd met de toepasselijke reglementering wordt gekapt. ${ }^{29 I}$ Men kan ook denken aan de organisator van een concert met een zanger over wiens privéleven de pers onjuiste informatie heeft verspreid, waardoor het concert minder publiek trekt dan normaal het geval zou zijn geweest, ${ }^{292}$ of aan de handelsagent die urenlang vastzit in de file als gevolg van een verkeersongeval en daardoor een belangrijke afspraak mist. ${ }^{293}$ Een ander voorbeeld is dit van de spoorwegmaatschap-

onder enkele banken en ongeveer 90.000 individuele beleggers. Het strafrechtelijk onderzoek naar fraude bij Lernout \& Hauspie leidde tot de inverdenkingstelling van 2I personen, waaronder de top van het bedrijf, bankinstelling Dexia en revisorenkantoor KPMG. De bijna I5.0oo beleggers die zich burgerlijke partij stelden, hoopten vooral op een veroordeling van 'deep pockets' Dexia en KPMG. Op 20 september 2010 deed het Gentse Hof van Beroep uitspraak over de strafzaak. Van de 2I beklaagden zijn er I 3 vrijgesproken. Ook KPMG en Dexia gaan vrijuit. Bovendien werd voor alle veroordeelden de beschuldiging 'emissiebedrog', waarbij via valse stukken de verkoop van aandelen uitgelokt werd, niet bewezen geacht.

290 Pinciples DCFR, 3348.

$29 \mathrm{I}$ D. De Marez, Afgeleide schade van aandeelhouders, 2 I3.

292 Principles DCFR, Vol. 4, 3 I47.

293 Principles DCFR, Vol. 4, 3I46. 
pij die extra kosten moet maken om de treinen om te leiden ten gevolge van een ongeval te wijten aan de fout van een derde.

Deze gevallen stellen naar Belgisch recht geen principiële problemen. Zoals eerder vermeld, past ons recht immers niet de leer van de relatieve onrechtmatigheid toe en komen ook zuivere vermogensbelangen in aanmerking voor bescherming door het aansprakelijkheidsrecht. Mits de weerslagschade zeker is (bijvoorbeeld een bewezen omzetverlies, bewezen kosten) en het conditio sine qua non-verband met de onrechtmatige daad kan worden aangetoond, heeft de benadeelde derde dan ook recht op vergoeding van zijn schade, ongeacht het doel van de geschonden norm en ongeacht de aard van zijn schade. Zo is geoordeeld dat de NMBS recht heeft op vergoeding voor de supplementaire kosten die de omleg van treinen meebrengt en waarvan het niet aannemelijk is dat de NMBS die kan doorrekenen aan het clientèle. ${ }^{294}$

Het aantonen van een zekere schade in causaal verband met de fout van de derde zal echter in gevallen als dit van de concertorganisator of van de handelsagent in de file vaak een struikelblok vormen. Tot nu toe zijn vorderingen tot vergoeding van de economische gevolgen van de files op onze wegen trouwens helemaal niet ingeburgerd. Blijkbaar wordt (thans nog) aanvaard dat dergelijke stoornissen behoren tot de normale risico's van het dagelijkse leven.

85. De opstellers van de DCFR tonen zich erg terughoudend om in gevallen als de voorgaande een recht op vergoeding toe te kennen voor de weerkaatste economische schade. Zo zijn zij van oordeel dat er in het geval van de concertorganisator geen 'legally relevant damage' is. Het risico dat er minder publiek komt opdagen als gevolg van onjuiste (negatieve) berichten in de pers, beschouwen zij als een risico dat elke organisator van evenementen moet ondergaan. Deze schade is te ver verwijderd en daarom niet juridisch relevant. ${ }^{295}$ Ook het inkomensverlies van de handelsagent die vastzit in de file en daardoor een belangrijke afspraak mist, komt in beginsel niet in aanmerking voor vergoeding omdat 'such types of obstacles are part and parcel of the everyday risks of life'. ${ }^{296}$

\section{Besluit}

86. Ondanks het erg ruime uitgangspunt dat elke persoon die schade lijdt als gevolg van een onrechtmatige daad gerechtigd is op vergoeding, leidt de toepassing van het Belgische aansprakelijkheidsrecht op het vlak van afgeleide schade van derden niet tot buitensporige resultaten. Om terug te keren naar de voorbeelden in de inleiding: ${ }^{297}$ een buur of een collega die erg is aangeslagen door het overlijden van het slachtoffer zal niet veel kans op succes hebben wanneer hij vergoeding

294 Antwerpen 27 maart I99I, RW I994-95, 366. Daarentegen is de vertraging van een trein op zichzelf geen schade voor de NMBS (Luik 25 november 1993 en Corr. Namen 20 maart 1992, De Verz. I994, 440).

295 Principles DCFR, Vol. 4, 3I47.

296 Principles DCFR, Vol. 4, 3I46.

297 Supra nr. 2. 
vordert voor zijn of haar smart (nog daargelaten het feit dat vorderingen van dergelijke 'naasten' nauwelijks voorkomen). ${ }^{298}$ Voor de apotheker die door het overlijden van het slachtoffer een goede klant verliest, zal het aantonen van een zekere schade (bewezen omzetverlies) in causaal verband met de fout van de derde een moeilijk te nemen hindernis zijn. ${ }^{299}$ En de werkgever die arbeidsprestaties derft omdat een aantal werknemers uren in de file staat als gevolg van een verkeersongeval zou daarvoor in theorie wel vergoeding kunnen vorderen, ${ }^{300}$ maar in de praktijk blijken werkgevers wel andere prioriteiten te hebben.

Behalve voor schuldeisers die verstoken blijven van de prestatie van hun schuldenaar als gevolg van de fout van een derde, liggen de oplossingen die de rechtspraak aanneemt voor schade van derden trouwens grotendeels in de lijn van de modelregels van de DCFR. In de praktijk is ons recht dus op het terrein van de derdenschade geen buitenbeentje in Europa. Dat komt omdat er ook bij ons grenzen worden gesteld aan de aansprakelijkheid voor afgeleide schade en aan de kring van aanspraakgerechtigden.

87. In het verleden gebeurde dit door in bepaalde gevallen het causaal verband tussen de schade en de onrechtmatige daad als doorbroken te beschouwen (denk bijvoorbeeld aan de kosten van interventies door publieke hulp- of veiligheidsdiensten) ${ }^{30}$ of door de rechtmatigheid van de aanspraak op vergoeding in vraag te stellen (denk aan de aanspraak van de ongehuwde partner). ${ }^{302}$ Ook de leer van de rechtskrenking werd verdedigd om een dam op te werpen tegen al te talrijke aanspraken van schadelijders bij weerkaatsing. ${ }^{303}$

Vandaag worden andere technieken gehanteerd.

88. Een eerste manier om de kring van aanspraakgerechtigden in te perken bestaat erin voor bepaalde schadesoorten alleen het directe slachtoffer als vergoedingsgerechtigd te beschouwen, ook al treft de schade in werkelijkheid (ook) anderen. Bij letselschade bijvoorbeeld maakt de rechtspraak geregeld abstractie van de omstandigheid dat de schade (vooral schade door gemaakte kosten of door het verlenen van hulp) in werkelijkheid anderen dan het rechtstreekse slachtoffer treft. ${ }^{304}$ Vanuit een zuiver concrete benadering zouden verplaatsingskosten, kosten van medische zorgen en hulp van derden als een persoonlijke schade beschouwd moeten worden van degene die daadwerkelijk de kosten maakt of de hulp verleent. Een dergelijke concrete benadering kan echter een versplintering van de schade over verschillende schadelijders en een toeloop van procespartijen met zich brengen. Dit vermijdt men door de schade te concentreren bij het slachtoffer. Concentratie van de schade bij

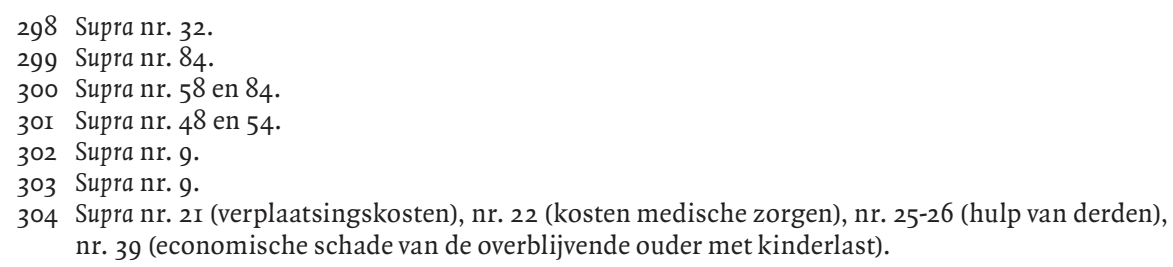


de direct benadeelde - en de daaruit voortvloeiende beperking van het aantal aanspraakgerechtigden - is ook het resultaat van de rechtspraak die aan individuele schuldeisers de mogelijkheid ontzegt om tijdens het faillissement van de schuldenaar voor hun afgeleide schade een vordering in te stellen tegen de aansprakelijke derde. ${ }^{305}$ Tot slot kan hier nog de klassieke leer worden vermeld volgens welke aan aandeelhouders geen eigen vorderingsrecht toekomt voor afgeleide schade die te herleiden is tot schade van de vennootschap zelf en waarvoor alleen de vennootschap kan beslissen (al dan niet) vergoeding te vorderen. ${ }^{306}$ De aansprakelijkheidsvordering wordt aldus geconcentreerd bij de primair benadeelde vennootschap.

89. Een tweede instrument waarover de rechter beschikt om de aansprakelijkheid voor afgeleide schade van derden binnen redelijke grenzen te houden, is zijn appreciatieruimte omtrent de zekerheid van de schade. Het bestaan van affectieschade wordt bijvoorbeeld niet gemakkelijk aanvaard voor verdere familieleden van het slachtoffer. ${ }^{307}$ Ook stellen sommige rechters bijzonder strenge eisen aan het bewijs van economische schade bij ongehuwde partners. ${ }^{308}$ De indruk ontstaat dat de beoordelingsvrijheid van de rechter omtrent de zekerheid van de aangevoerde schade in dergelijke gevallen soms wordt aangewend om schade die ver verwijderd is van de onrechtmatige daad of die voortvloeit uit de aantasting van belangen die, hoewel rechtmatig, naar het oordeel van de rechter geen bescherming verdienen, te weren uit het toepassingsveld van artikel $1_{3} 82 \mathrm{BW} \cdot{ }^{309}$ Ook voor schuldeisers is het vaak niet eenvoudig om hard te maken dat hun schade een voldoende zeker karakter heeft..$^{\text {io }}$

90. Recent wordt ook het schadebegrip zelf ingezet voor de begrenzing van de aansprakelijkheid. De uitkeringen die sommige derde-betalers (waaronder schadeverzekeraars en arbeidsongevallenverzekeraars) aan de benadeelde moeten doen op grond van een wettelijke of contractuele verplichting, maken volgens het Hof van Cassatie geen vergoedbare schade uit. ${ }^{3 \mathrm{II}}$ Ook de kosten van bepaalde interventies van publieke hulp- en veiligheidsdiensten (denk aan brandbestrijding) worden niet als vergoedbare schade beschouwd. ${ }^{312}$ De redenen waarom deze uitkeringen en kosten geen vergoedbare schade vormen, zijn niet duidelijk op te maken uit de rechtspraak van het Hof van Cassatie. Het criterium volgens hetwelk uitgaven verricht op grond van een wettelijke of contractuele verplichting schade uitmaken behalve wanneer zij blijkens de inhoud of de strekking van de wet of het contract definitief ten laste moeten blijven van degene die ze moet verrichten, is in de praktijk niet gemakkelijk te hanteren omdat de toepasselijke wet of het contract daarover vaak geen uitsluit-

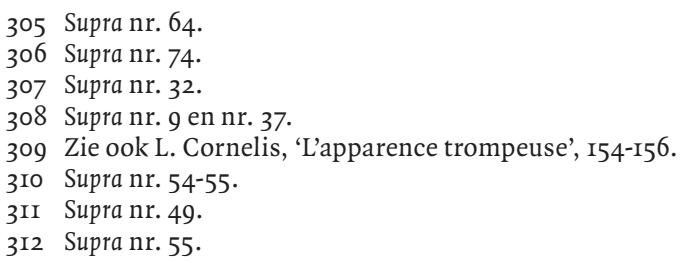


sel geeft. Het criterium is bovendien niet afdoend: ook de schadeverzekeraar en de arbeidsongevallenverzekeraar moeten de last van de uitkeringen - blijkens het hen toegekende wettelijke subrogatierecht - niet definitief dragen; toch lijden zij volgens het Hof van Cassatie geen vergoedbare schade. Achter het oordeel dat de uitgaven definitief voor hun rekening moeten blijven volgens de strekking van de wet of het contract, gaan andere motieven schuil. ${ }^{313}$

9I. Het theoretische uitgangspunt dat elke derde die een feitelijk nadeel ondervindt als gevolg van een aan het rechtstreekse slachtoffer onrechtmatig veroorzaakte schade, aanspraak kan maken op vergoeding, strookt dus niet met de werkelijkheid. Er worden wel degelijk keuzes gemaakt. ${ }^{314}$ Alleen worden die keuzes verhuld door het persoonlijk karakter of de zekerheid van de schade te ontkennen of door het nadeel als niet vergoedbaar te bestempelen op grond van de strekking van de toepasselijke wet of het contract. Dat is rationeel onbevredigend, omdat de werkelijke redenen van de keuze verborgen blijven. Met het oog op een grotere transparantie en voorspelbaarheid van het aansprakelijkheidsrecht, zou het beter zijn uitdrukkelijk te erkennen dat ons aansprakelijkheidsrecht er niet noodzakelijk toe strekt elk (rechtmatig) belang bescherming te bieden en dat uitzonderingen mogelijk zijn. Ongetwijfeld zal hiertegen als bezwaar worden geuit dat, volgens de tekst van artikel I382 BW en de bedoeling van de opstellers van het BW, wél elke schade die voortvloeit uit een onrechtmatige daad onder het beschermingsbereik van het aansprakelijkheidsrecht moet vallen..$^{35}$ Men kan daar tegenover stellen dat de opstellers van de Code civil de moderne complexe samenleving met de toename van het aantal relaties en banden die elke persoon heeft met anderen en de daaruit voortvloeiende multiplicatie van belangen, niet konden voorzien. ${ }^{316}$ De realiteit is dat niet elk feitelijk nadeel, ook al vloeit het voort uit de aantasting van een persoonlijk en rechtmatig belang, wordt vergoed en dat er dus grenzen worden getrokken. De vraag is alleen hoe die begrenzing van de aansprakelijkheid op een rationeel bevredigende en nietwillekeurige wijze juridisch kan worden verantwoord.

Wij menen dat het schadebegrip als aanknopingspunt voor een dergelijke verantwoording kan dienen. Het kan die functie echter alleen vervullen als men aanvaardt dat een louter feitelijke invulling van de schade als het negatieve verschil tussen twee toestanden niet volstaat. Zoals Bocken opmerkt, is die omschrijving immers alleen nuttig om de aard en de omvang van schade vast te stellen (en wat de omvang betreft dan nog met uitzondering van morele schade), maar geeft zij geen inhoudelijke aanwijzing over wat schade is. ${ }^{37}$ Dat schade niet louter een feitelijk gegeven is maar tevens een juridisch begrip, zodat de vraag naar het aanwezig zijn van schade een rechtsvraag is, wordt trouwens algemeen aanvaard. Als rechtsbegrip kan de schade

3 I3 Supra nr. 50.

3 I4 Zie ook E. De Kezel, 'Juridische bescherming van niet-vermogensrechtelijke belangen', TPR 2003, (50I) 533-534.

3 I5 Zie supra nr. 2 en de doctrine vermeld in voetnoot 13.

3 I6 Zie ook J.-S. Borghetti, 'Les intérêts protégés', (I45) I60.

317 H. Bocken, 'Geen kans verloren', (27I) 300-30I, nr. 38. 
omschreven worden als de aantasting van een juridisch beschermd belang. $\cdot^{318}$ De consequentie hiervan is dat, zoals een deel van de doctrine recent ook erkent inzake causaliteit, ${ }^{319}$ de vaststelling van de vergoedbare schade in twee stappen gebeurt: de eerste stap is de vaststelling van een feitelijk nadeel; de tweede stap bestaat in de beslissing of dit feitelijk nadeel juridisch relevant is, dit wil zeggen of dit nadeel voortvloeit uit de aantasting van een beschermd belang. Daarbij moet het uitgangspunt blijven dat elk rechtmatig belang in beginsel voor bescherming in aanmerking komt. Alleen zou de rechter de mogelijkheid hebben om - openlijk - te beslissen dat in bepaalde gevallen geen beschermwaardig belang voorligt. Die beslissing, waarop het Hof van Cassatie (marginaal) toezicht zou houden, berust op een belangenafweging waarin de rechter, naar het voorbeeld van de DCFR-modelregel inzake 'legally relevant damage', ${ }^{320}$ een aantal criteria kan betrekken, zoals de aard van de fout en de grondslag van de aansprakelijkheid, de aard van de schade en haar afstand tot de onrechtmatige daad en beleidsoverwegingen met betrekking tot het algemeen belang en met betrekking tot de interne coherentie van het (privaat)recht.

92. De hier voorgestelde benadering lijkt misschien ver af te staan van het traditionele uitgangspunt dat de ruime regel van artikel I3 $82_{2} \mathrm{BW}$ de aanspraak erkent van elke persoon die schade (begrepen als een feitelijk nadeel) heeft geleden als gevolg van de onrechtmatige daad. De afstand is in werkelijkheid veel geringer wanneer men zich er rekenschap van geeft dat dergelijke criteria nu reeds aangewend worden, zij het op een verhulde manier, om in bepaalde gevallen aan de eiser een vergoeding te weigeren ook al heeft hij onmiskenbaar een zeker persoonlijk nadeel geleden ten gevolge van de onrechtmatige daad. Wanneer de rechtspraak bijzonder terughoudend is om aan verdere verwanten van het slachtoffer een vergoeding toe te kennen voor morele schade, dan is dat meestal niet omdat die verdere verwanten geen smart zouden ondervinden, maar wel omdat de rechter van oordeel is dat hun schade te ver verwijderd is. Wanneer rechtspraak en rechtsleer het erover eens zijn dat de overheid geen vergoeding kan vorderen van de aansprakelijke voor de kosten van brandbestrijding, dan is dat niet omdat die kosten voor de overheid geen feitelijk nadeel als gevolg van de fout uitmaken, maar wel omdat men, op grond van beleidsoverwegingen met betrekking tot het algemeen belang, van oordeel is dat de overheid voor dergelijke kosten geen verhaal behoort te hebben op individuele burgers. ${ }^{321}$

Het Hof van Cassatie zou de toon kunnen zetten door in gevallen waarin het nu kortweg zegt dat een bepaalde eiser niet als schadelijder kan worden beschouwd, die beslissing nader te verantwoorden en aan te geven waarom het aangetaste belang

3I8 H. Bocken, 'Geen kans verloren', (27I) 300-30I, nr. 38; J.-S. Borghetti, 'Les intérêts protégés', (I45) I55-I56.

3 I9 H. Bocken, 'Toerekening van aansprakelijkheid op grond van de equivalentieleer', in B. Tilleman en I. Claeys (eds.), Buitencontractueel aansprakelijkheidsrecht, Brugge, die Keure, 2004, (2I3) 2I6-2I7; W. Van Gerven m.m.v. S. Covemaeker, Verbintenissenrecht, $4 \mathrm{I} 7$ e.v.

320 Supra nr. 13.

32I Behoudens eventueel bij opzettelijke brandstichting. De aard van de fout kan in dit geval verantwoorden dat er toch sprake is van een beschermwaardig belang. 
niet voor bescherming door het aansprakelijkheidsrecht in aanmerking komt. Wat bijvoorbeeld de schadeverzekeraar betreft, zou de verantwoording kunnen luiden dat de betaling van de verzekeringsvergoeding bij verwezenlijking van het gedekte risico de essentie van het verzekeringscontract uitmaakt en de onrechtmatige daad waardoor het risico zich verwezenlijkt de normale werking van de overeenkomst dus niet verstoort. Daarom komt zijn belang niet in aanmerking voor bescherming door het aansprakelijkheidsrecht. 